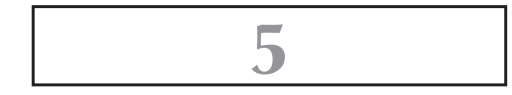

\title{
ASPECTOS FORMAIS DAS TRANSFERÊNCIAS VOLUNTÁRIAS
}

No presente capítulo, serão abordados os principais aspectos formais concernentes aos convênios e aos contratos de repasse, principais instrumentos jurídicos de operacionalização das transferências voluntárias de recursos.

\subsection{INSTRUMENTOS DE EFETIVAÇÃO DAS TRANSFERÊNCIAS VOLUNTÁRIAS: CONVÊNIOS E CONTRATOS DE REPASSE}

Os convênios representam um importante instrumento de descentralização administrativa, voltados à implementação de programas governamentais com prazo de duração determinado. Diante das dificuldades enfrentadas para a consecução direta das ações inseridas na programação do governo, os entes federados, notadamente Uniāo e Estados, valem-se de tais mecanismos como forma de viabilizar a consecução de seus objetivos, por meio de parcerias com outros entes da federação ou entidades privadas sem fins lucrativos.

Conforme clássica definição doutrinária, bem delimitada pelo conceito trazido por Maria Sylvia Zanella Di Pietro, convênio é a "forma de ajuste entre o Poder Público e entidades públicas ou privadas para a realização de objetivos de interesse comum, mediante mútua colaboração". ' Outra definição bastante ilustrativa pode ser extraída do Portal do Tribunal de Contas da União, já restrita, no entanto, aos convênios enquanto um dos principais instrumentos de veiculação das transferências voluntárias:

1 PIETRO, Maria Sylvia Zanella di. Direito administrativo. 28. ed. São Paulo: Atlas, 2015, p. 386. 
Convênio é o instrumento formal que disciplina a transferência de recursos públicos da União para os Estados, Municípios etc. Convênios celebrados por órgãos e entidades da Administração regulam-se pelas disposições pelas normas da Lei de Licitaçóes - Lei n. 8.666, de 1993 - e da IN STN n. 01, de 1997, que disciplina a celebração de convênios de natureza financeira que tenham por objeto a execução de projetos ou realização de eventos. A celebração de convênio não abrange apenas repasses de recursos federais para estados e/ou Municípios, embora seja o mais comum. Os convênios podem ser feitos entre quaisquer órgãos ou entidades da Administração Pública, ou seja, no âmbito federal, estadual ou municipal. A efetivação de um convênio depende de prévia aprovação de minucioso plano de trabalho proposto pela organização interessada em celebrar o convênio. Logo depois da assinatura do convênio, o partícipe repassador dos recursos deve dar ciência do feito à Assembleia Legislativa ou à Câmara Municipal respectiva. ${ }^{2}$

Verifica-se, assim, que os convênios podem ou não dispor de natureza financeira, havendo a possibilidade de celebração de acordos que não envolvam a transferência de recursos entre os partícipes, como os convênios de cooperação técnica, os destinados à execução descentralizada de programas federais de atendimento direto ao público, nas áreas de assistência social, médica e educacional, ou os que tenham por objeto a delegação de competência ou a autorização a órgãos ou entidades de outras esferas de governo para a execução de atribuições determinadas em lei, regulamento ou regimento interno, entre outras modalidades. Interessam para o presente estudo os convênios que envolvem a transferência de recursos financeiros voltados à execução de projetos ou à realização de eventos.

A esse propósito, convém trazer a lume a clara definição de Guilherme Henrique de La Rocque Almeida:

O convênio consiste no compromisso firmado por um ente da Administração Pública, que esteja gerindo recursos orçamentários, de repassar determinado montante de recursos a uma instituição de qualquer esfera de governo (Federal, Estadual, Municipal ou do Distrito Federal) ou a uma organização particular, que se comprometa a realizar as ações constantes das cláusulas conveniadas, em consonância com o respectivo Plano de Trabalho. Além disso, o ente que receber os recursos federais transferidos deverá, posteriormente, prestar contas da aplicação de tais recursos. ${ }^{3}$

Transpondo o conceito à realidade das transferências voluntárias, deve-se atentar para a natureza dos concedentes e convenentes, tendo em vista que apenas os entes federados, de um lado e de outro, poderão celebrar convênios com vistas à

2 BRASIL. Tribunal de Contas da União. Licitaçôes \& contratos: orientações básicas. 3. ed. Brasília: TCU, Secretaria de Controle Interno, 2006, p. 252. Grifo nosso.

3 ALMEIDA, Guilherme Henrique de La Rocque. Controle das transferências financeiras da uniāo. Belo Horizonte: Fórum, 2008, p. 110. 
realização de transferências voluntárias de recursos, nos estritos termos veiculados pelo artigo 25 da Lei de Responsabilidade Fiscal.

Da mesma forma como os convênios não se destinam exclusivamente à instrumentalização da destinação de recursos por meio de transferências voluntárias, admitindo outras finalidades, a realização dessas transferências também não se limita aos convênios, admitindo outros instrumentos, em especial, os contratos de repasse.

Os contratos de repasse são qualificados pela Portaria Interministerial CGU/MF/ MP n. 507, de 2011, como o "instrumento administrativo por meio do qual a transferência dos recursos financeiros processa-se por intermédio de instituição ou agente financeiro público federal, atuando como mandatária da União" (art. 1º, inciso IV).

Não obstante a terminologia "contrato", muitas das diferenças apontadas pela doutrina entre convênios e contratos, baseadas nas características próprias de cada um dos instrumentos jurídicos, não estão presentes nos contratos de repasse. Assim, não se verificam interesses opostos e contraditórios, nem os valores recebidos passam a integrar o patrimônio dos entes contratados, características presentes nos contratos. Ao contrário, nos contratos de repasse são encontrados elementos típicos dos convênios, como a mútua colaboração e a existência de objetivos comuns. Da mesma forma, os valores recebidos devem ser aplicados estritamente na finalidade ajustada. Conclui-se, assim, que a natureza contratual não deve servir como elemento diferenciador entre os instrumentos de transferências voluntárias, mas sim a presença da instituição financeira enquanto intermediária do ajuste contratual.

Observa-se, no entanto, que a concepção de contrato adotada pela Lei Federal n. 8.666/93 se afasta da concepção tradicional do instituto, permitindo uma amplitude conceitual com vistas à plena aplicação de seus termos. Nesse sentido, dispõe o parágrafo único do artigo $2^{\circ}$ do mencionado diploma:

Para os fins desta Lei, considera-se contrato todo e qualquer ajuste entre órgãos ou entidades da Administração Pública e particulares, em que haja um acordo de vontades para a formação de vínculo e estipulação de obrigaçōes recíprocas, seja qual for a denominação utilizada.

Dessa maneira, conclui-se que os contratos de repasse possuem natureza jurídica muito mais próxima à dos convênios do que propriamente aos contratos, não obstante a terminologia utilizada, tendo em vista a natureza cooperativa que os norteia, submetendo-se, de qualquer forma, aos termos da legislação que rege os convênios. Nesse sentido, pontua Jessé Torres Pereira Júnior ao tecer comentários ao artigo 116 da Lei Federal n. 8.666/93:

Como o art. 116 é uma cunha no sistema da Lei n. 8.666/93, voltado para a disciplina dos contratos da Administração, parece fora de dúvida que o art. 116 destina-se 
tão-só a fixar regras gerais mínimas de comportamento administrativo nos convênios, admitindo-se que ajustes ou acordos sejam àqueles equiparados desde que qualificados como de cooperação.

No mais das vezes, propõe-se no convênio que um ente público repasse recursos financeiros para que outro ente, entidade vinculada ou empresa privada realize projeto de interesse público de competência comum ou concorrente, a nenhum deles movendo o fim de lucro, figura de todo estranha ao convênio. Tanto o ente fornecedor dos recursos como aqueles que os aplicarão estão vinculados à consecução do projeto, do qual não se poderão desviar os meios repassados ou mobilizados pelo convênio. A origem dos recursos, a finalidade para que predispostos, e sua vinculação a procedimentos de ordem pública justificam o zelo com que a Lei n. 8.666/93 entendeu de empenhar no art. 116, aproximando-o das cautelas com que cuidou dos contratos. ${ }^{4}$

Observa-se, dessa forma, a submissão dos contratos de repasse aos regramentos veiculados pelo artigo 116 da Lei Federal n. 8.666/93 voltados aos convênios, acordos, ajustes e outros instrumentos congêneres.

Também não há distinção em razão da origem dos recursos empregados, sendo ambos decorrentes do Orçamento Geral do ente concedente. Nesse sentido, consoante apontam João Paulo Ciribeli, Samuel Miquelito e Wellington de Oliveira Massardi:

No que se refere à origem dos recursos, tanto os convênios quanto os dos contratos de repasse estão alocados no Orçamento Geral da União - OGU ou no Orçamento Geral do dos Estado - OGE, podendo ser de duas formas: contemplação nominal (por meio de proposta do Executivo ou de emenda ao Orçamento da União por Deputado Federal ou Senador), ou não contemplação explícita, em que os recursos encontram-se no programa orçamentário e destinado aos órgãos pretendentes afirmar o convênio. $\mathrm{O}$ acesso aos recursos se dá por meio de proposta ou projeto formulado pelo próprio interessado diretamente ao Ministério/Secretaria ou à entidade que disponha de recursos aplicáveis ao objeto pretendido, ou quando se deseja implementar programas federais (OGU, 2012). ${ }^{5}$

A diferença básica e conceitual entre os instrumentos consiste na intermediação das transferências efetuadas em contratos de repasse por instituição ou agente financeiro público federal, que atua como mandatário da União (art. 1º, inciso II do Decreto Federal n. 6.170/2007). Nesse sentido, o Decreto n. 6.170, de 25 de julho de 2007, que dispõe sobre as normas relativas às transferências de recursos da União mediante convênios e contratos de repasse, contempla as seguintes definições:

4 PEREIRA JÚNIOR, Jessé Torres. Comentários à lei das licitaçôes e contrataçôes da administração pública. 6. ed. rev., atual. e ampl. Rio de Janeiro: Renovar, 2003, p. 950. Grifo nosso.

5 CIRIBELI, João Paulo; MIQUELITO, Samuel; MASSARDI, Wellington de Oliveira. Transferências públicas de recursos: um estudo sobre o protecionismo partidário da união (PT) e do Estado de Minas Gerais (PSDB). Administração Pública e Gestão Social, v. 7, n. 2, p. 72-81, abr./jun. 2015, p. 74. 
Quadro 5.1 Convênio e contrato de repasse no Decreto Federal n. 6.170/2007

\begin{tabular}{|c|l|}
\hline & $\begin{array}{l}\text { acordo, ajuste ou qualquer outro instrumento que discipline a transferência } \\
\text { de recursos financeiros de dotações consignadas nos Orçamentos Fiscal e da } \\
\text { Seguridade Social da União e tenha como partícipe, de um lado, órgão ou entidade } \\
\text { da administração pública federal, direta ou indireta, e, de outro lado, órgão ou } \\
\text { entidade da administração pública estadual, distrital ou municipal, direta ou indireta, } \\
\text { ou ainda, entidades privadas sem fins lucrativos, visando a execução de programa de } \\
\text { governo, envolvendo a realização de projeto, atividade, serviço, aquisição de bens ou } \\
\text { INCISO I } \\
\text { evento de interesse recíproco, em regime de mútua cooperação; }\end{array}$ \\
\hline $\begin{array}{c}\text { CONTRATO } \\
\text { DE REPASSE } \\
\text { ARTIGO 10, } \\
\text { INCISO II }\end{array}$ & $\begin{array}{l}\text { instrumento administrativo, de interesse recíproco, por meio do qual a } \\
\text { transferência dos recursos financeiros se processa por intermédio de instituição ou } \\
\text { agente financeiro público federal, que atua como mandatário da União }\end{array}$ \\
\hline
\end{tabular}

Fonte: elaboração própria a partir do Decreto Federal n. 6.170/2007.

A Cartilha SICONV para os Municípios também conceitua e diferencia os instrumentos, no seguinte sentido:

\section{CONVÊNIO}

Parceria formalizada entre a União e o Município para a execução de programa de governo. Envolve a realização de projeto, atividade, serviço, aquisição de bens ou realização de eventos, em regime de mútua cooperação, ou seja, quando há interesse recíproco entre as partes.

\section{CONTRATO DE REPASSE}

Instrumento por meio do qual a transferência voluntária dos recursos financeiros é realizada por instituição financeira pública federal, que atua como mandatária da União. Estas instituições são representadas pelo Banco do Brasil, Banco do Nordeste, Banco da Amazônia e Caixa Econômica Federal. O contrato de repasse vem sendo utilizado pelo governo federal predominantemente para a execução de programas sociais nas áreas de habitação, saneamento e infraestrutura urbana, esporte, bem como nos programas relacionados à agricultura. ${ }^{6}$

Observe-se que foi considerada a natureza dos destinatários da cartilha - no caso, os Municípios - na definição do convênio como parceria formalizada entre a União e o Município, não prevalecendo a limitação imposta na definição.

Nessa medida, além da intermediação das transferências, que se verifica apenas nos contratos de repasse, outra diferenciação a ser apontada reside na finalidade dos

6 BRASIL. Ministério do Planejamento, Orçamento e Gestão. Cartilha SICONV para municípios: o sistema de gestão das transferências voluntárias da união - SICONV como ferramenta para captação de recursos federais pelos Municípios. Brasília: Portal dos Convênios SICONV, [2013?], p. 2. 
convênios e dos contratos de repasse. Muito embora não haja uma distinção rigorosa, em tese os convênios destinam-se à "realização de projeto, atividade, serviço, aquisição de bens ou realização de eventos, em regime de mútua cooperação, ou seja, quando há interesse recíproco entre as partes", enquanto os contratos de repasse destinam-se predominantemente à "execução de programas sociais nas áreas de habitação, saneamento e infraestrutura urbana, esporte, bem como nos programas relacionados à agricultura".

Verifica-se, dessa forma, que os convênios e os contratos de repasse, representativos dos principais instrumentos de consecução das transferências voluntárias, diferenciam-se eminentemente por seus aspectos formal (intermediação ou não de instituição financeira) e finalístico.

Conforme dados extraídos do portal do governo eletrônico, ${ }^{8}$ em termos de compromissos assinados, o maior volume de transferências voluntárias é alcançado pelos contratos de repasse, seguidos pelos convênios. Apenas um pequeno percentual é operado por meio dos termos de parceria, instrumentos utilizados para a transferência de recursos para organizaçóes sociais de interesse público.

Tabela 5.1 Modalidades de aplicação por exercício financeiro

\begin{tabular}{|l|c|c|c|c|c|}
\hline $\begin{array}{c}\text { MODALIDADES } \\
\text { DE APLICAÇÃO/ } \\
\text { EXERCíCIOS }\end{array}$ & $\mathbf{2 0 0 9}$ & $\mathbf{2 0 1 0}$ & $\mathbf{2 0 1 1}$ & $\mathbf{2 0 1 2}$ & $\mathbf{2 0 1 3}$ \\
\hline Contratos de repasse & $23,5 \%(1.637)$ & $66,1 \%(19.040)$ & $50,2 \%(4.636)$ & $62,6 \%(6,774)$ & $66,9 \%(7.652)$ \\
\hline Convênios & $76,2 \%(5.300)$ & $33,7 \%(9.694)$ & $49,73 \%(4.592)$ & $37,3 \%(4.043)$ & $32,9 \%(3.762)$ \\
\hline Termos de parceria & $0,3 \%(19)$ & $0,2 \%(54)$ & $0,2 \%(15)$ & $0,08 \%(9)$ & $0,1 \%(16)$ \\
\hline
\end{tabular}

Fonte: elaboração própria a partir de BRASIL. Ministério do Planejamento, Orçamento e Gestão, Secretaria de Logística e Tecnologia da Informação - SLTI. Informaçôes Gerenciais e Transferências Voluntárias da União - janeiro a novembro de 2013. Brasília: Ministério do Planejamento, Orçamento e Gestão, [2014?].

No entanto, em termos de volume de recursos despendidos, os convênios acabam alcançando o primeiro lugar, conforme se verifica da tabela abaixo:

7 BRASIL. Ministério do Planejamento, Orçamento e Gestão, cit.

8 BRASIL. SICONV em números - 2009 e 2010 - percentual de transferências voluntárias assinadas por modalidade e ano da assinatura. Portal Governo Eletrônico. Disponível em: <http://www.governoeletronico.gov.br/acoes-e-projetos/convenios/siconv-em-numeros-2009-e-2010/percentual-de-transferencias-voluntarias-assinadas-por-modalidade-e-ano-da-assinatura/>. Acesso em: 06 out. 2014. 
Tabela 5.2 Valor das transferências voluntárias da União por modalidade (em R\$)

\begin{tabular}{|c|c|c|c|c|}
\hline ANO & $\begin{array}{c}\text { CONTRATO DE } \\
\text { REPASSE }\end{array}$ & CONVÊNIO & $\begin{array}{c}\text { TERMO DE } \\
\text { PARCERIA }\end{array}$ & TOTAL \\
\hline $\mathbf{2 0 0 9}$ & 699 milhões & 5,794 bilhões & 44 milhões & 6,539 bilhões \\
\hline $\mathbf{2 0 1 0}$ & 8,216 bilhões & 8,105 bilhões & 282 milhões & 16,604 bilhões \\
\hline $\mathbf{2 0 1 1}$ & 2,033 bilhões & 5,240 bilhões & 90 milhões & 7,364 bilhões \\
\hline $\mathbf{2 0 1 2}$ & 3,844 bilhões & 5,330 bilhões & 314 milhões & 9,489 bilhões \\
\hline $\mathbf{2 0 1 3}$ & 5,309 bilhões & 5,945 bilhões & 726 milhões & 11,981 bilhões \\
\hline
\end{tabular}

Fonte: elaboração própria a partir de BRASIL. Ministério do Planejamento, Orçamento e Gestão, Secretaria de Logística e Tecnologia da Informação - SLTI, cit., p. 126.

Tabela 5.3 Valor global das transferências entre 2009 a 2013, por modalidade de aplicação

\begin{tabular}{|l|c|}
\hline \multicolumn{1}{|c|}{ MODALIDADE DE APLICAÇÃo } & $\begin{array}{c}\text { VALOR DE REPASSE DAS TRANSFERÊNCIAS } \\
\text { PERÍODO DE 2009 A 2013 }\end{array}$ \\
\hline Contratos de repasse & $\mathrm{R} \$ 20.103 .211 .060,73$ \\
\hline Convênios & $\mathrm{R} \$ 30.416 .245 .876,88$ \\
\hline Termos de parceria & $\mathrm{R} \$ 1.459 .542 .215,40$ \\
\hline
\end{tabular}

Fonte: elaboração própria a partir de BRASIL. Ministério do Planejamento, Orçamento e Gestão, Secretaria de Logística e Tecnologia da Informação - SLTI, cit., p. 126.

Observa-se, assim, da análise da Tabela 5.3, que em termos de volume de recursos, os percentuais aproximados alcançados são 58,51\% (convênios), 38,67\% (contratos de repasse) e 2,80\% (termos de parceria).

\subsubsection{Fundamento legal e requisitos}

Afora a importância ostentada na atividade administrativa propriamente dita, destaca-se a ausência de legislação ordinária mais detalhada sobre os convênios, que contam com expressa previsão legal no artigo 116 da Lei Federal n. 8.666/93. ${ }^{9}$

9 Dispõe o art. 116: Aplicam-se as disposiçôes desta Lei, no que couber, aos convênios, acordos, ajustes e outros instrumentos congêneres celebrados por órgãos e entidades da Administração. $\$ 1^{\circ}$ A celebração de convênio, acordo ou ajuste pelos órgãos ou entidades da Administração Pública depende de prévia aprovação de competente plano de trabalho proposto pela organização interessada, o qual deverá conter, no mínimo, as seguintes informações: 
Desse dispositivo, que representa fundamento para todo o arcabouço normativo infralegal que rege a matéria, extraem-se os requisitos básicos para a sua celebração. Entre os requisitos previstos pelo artigo 116 da Lei de Licitações, destacam-se:

a) prévia apresentação de plano de trabalho pela organização interessada, que deverá necessariamente conter:

1. a identificação do objeto a ser executado;

I - identificação do objeto a ser executado;

II - metas a serem atingidas;

III - etapas ou fases de execução;

IV - plano de aplicação dos recursos financeiros;

$\mathrm{V}$ - cronograma de desembolso;

VI - previsão de início e fim da execução do objeto, bem assim da conclusão das etapas ou fases programadas;

VII - se o ajuste compreender obra ou serviço de engenharia, comprovação de que os recursos próprios para complementar a execução do objeto estão devidamente assegurados, salvo se o custo total do empreendimento recair sobre a entidade ou órgão descentralizador.

$\$ 2^{\circ}$ Assinado o convênio, a entidade ou órgão repassador dará ciência do mesmo à Assembléia Legislativa ou à Câmara Municipal respectiva.

$\$ 3^{\circ}$ As parcelas do convênio serão liberadas em estrita conformidade com o plano de aplicação aprovado, exceto nos casos a seguir, em que as mesmas ficarão retidas até o saneamento das impropriedades ocorrentes:

I - quando não tiver havido comprovação da boa e regular aplicação da parcela anteriormente recebida, na forma da legislação aplicável, inclusive mediante procedimentos de fiscalização local, realizados periodicamente pela entidade ou órgão descentralizador dos recursos ou pelo órgão competente do sistema de controle interno da Administração Pública;

II - quando verificado desvio de finalidade na aplicação dos recursos, atrasos não justificados no cumprimento das etapas ou fases programadas, práticas atentatórias aos princípios fundamentais de Administração Pública nas contratações e demais atos praticados na execução do convênio, ou o inadimplemento do executor com relação a outras cláusulas conveniais básicas; III - quando o executor deixar de adotar as medidas saneadoras apontadas pelo partícipe repassador dos recursos ou por integrantes do respectivo sistema de controle interno.

$\$ 4^{\circ}$ Os saldos de convênio, enquanto não utilizados, serão obrigatoriamente aplicados em cadernetas de poupança de instituição financeira oficial se a previsão de seu uso for igual ou superior a um mês, ou em fundo de aplicação financeira de curto prazo ou operação de mercado aberto lastreada em títulos da dívida pública, quando a utilização dos mesmos verificar-se em prazos menores que um mês.

$\$ 5^{\circ}$ As receitas financeiras auferidas na forma do parágrafo anterior serão obrigatoriamente computadas a crédito do convênio e aplicadas, exclusivamente, no objeto de sua finalidade, devendo constar de demonstrativo específico que integrará as prestações de contas do ajuste. $\$ 6^{\circ}$ Quando da conclusão, denúncia, rescisão ou extinção do convênio, acordo ou ajuste, os saldos financeiros remanescentes, inclusive os provenientes das receitas obtidas das aplicações financeiras realizadas, serão devolvidos à entidade ou órgão repassador dos recursos, no prazo improrrogável de 30 (trinta) dias do evento, sob pena da imediata instauração de tomada de contas especial do responsável, providenciada pela autoridade competente do órgão ou entidade titular dos recursos. 
2. as metas a serem atingidas;

3. as etapas ou fases de execução;

4. o plano de aplicação dos recursos financeiros;

5. o cronograma de desembolso;

6. a previsão do início e fim da execução do objeto, bem como da conclusão das etapas ou fases programadas;

7. a previsão de contrapartida se o ajuste compreender obra ou serviço de engenharia.

b) comunicação à Casa Legislativa respectiva. O objetivo é apenas conferir ciência da celebração do ajuste, com vistas ao exercício de eventual fiscalização por parte do Poder Legislativo.

Maria Sylvia Zanella Di Pietro aponta a redação imprecisa do dispositivo:

A redação do dispositivo não é muito feliz, porque dá a impressão de que somente se aplica a ajustes que tenham por objeto a realização de "projetos" ou, por outras palavras, um resultado determinado (uma obra, um serviço, um parecer, um laudo etc.), com repasse de verbas de uma entidade para outra. Isto nem sempre ocorre, tendo em vista que, em determinadas hipóteses, o objetivo do convênio é o de estabelecer a mútua colaboração para a prestação de serviços contínuos a terceiros, em áreas como educação, ensino, cultura, por exemplo; além disso, nem sempre a mútua colaboração envolve repasse de verbas. ${ }^{10}$

Os requisitos relacionados à prévia apresentação de plano de trabalho pela organização interessada, assim como a previsão de comunicação à Casa Legislativa para propiciar um controle mais efetivo das transferências de recursos realizadas, são minuciosamente detalhados pela legislação infralegal que rege a matéria, em especial a Portaria Interministerial CGU/MF/MP n. 507/2011, e serão objeto de oportuna abordagem.

Além dos requisitos concernentes ao plano de trabalho e à respectiva comunicação ao Poder Legislativo, o dispositivo ainda trata de outros aspectos, relacionados especialmente à liberação das parcelas dos convênios, bem como à aplicação dos saldos deles em cadernetas de poupança ou fundos de aplicação. A esse propósito, o dispositivo é claro ao prever a necessidade de aplicação dos recursos enquanto se aguarda sua utilização, a reversão dos recursos auferidos aos objetivos do convênio e a sua devolução ao órgão repassador ao término da relação, aspectos que serão mais bem elucidados por ocasião da análise da regulamentação da matéria feita pelos órgãos do Poder Executivo.

10 PIETRO, Maria Sylvia Zanella di, cit., p. 389. 
Ainda nesse sentido, convém esclarecer que, a partir da previsão veiculada pelo artigo 116 da Lei Federal n. 8.666/93, foram editados outros atos de natureza infralegal que disciplinam a celebração de ajustes envolvendo o repasse de recursos financeiros entre os entes da federação.

\subsubsection{Evolução da regulamentação infralegal das transferências voluntárias}

Um importante instrumento regulamentador dos convênios é a Instrução Normativa n. 1/97, da Secretaria do Tesouro Nacional, editada com o objetivo de regulamentar a celebração e a execução de convênio de natureza financeira para fins de execução descentralizada de Programa de Trabalho de responsabilidade de órgão ou entidade da Administração Pública federal direta e indireta. Ainda que sua relevância enquanto instrumento normativo regulamentador das transferências voluntárias tenha perdurado até a edição do Decreto n. 6.170, de 25 de julho de 2007, que dispõe sobre as normas relativas às transferências de recursos da União mediante convênios e contratos de repasse, mencionado diploma apresenta um papel de relevo na evolução histórica da regulamentação das transferências voluntárias.

A Instrução Normativa n. 1/97 disciplinou de forma bastante minuciosa os requisitos exigíveis dos convenentes, particularmente no tocante à sua qualificação e ao detalhamento dos projetos. De acordo com o artigo $2^{\circ}$ do mencionado diploma, o interessado no recebimento dos recursos disponibilizados pelos órgãos governamentais deve apresentar justificativas para a celebração do convênio (inciso I), ao lado de uma descrição completa e minuciosa do objeto a ser executado (inciso II), das metas a serem atingidas (inciso III), das etapas e fases de execução do objeto (inciso IV), do plano de aplicação dos recursos desembolsados pelo concedente e a contrapartida financeira, se for o caso (inciso VI), do cronograma de desembolso (inciso VI), além da licença ambiental prévia, quando o convênio envolver obras, instalações ou serviços que exijam estudos ambientais (inciso III-A).

No tocante à qualificação, o interessado deve comprovar que não se encontra em situação de mora ou inadimplência perante órgão ou entidade da Administração Pública Federal Direta e Indireta (inciso VII) e que exerce plenamente os poderes inerentes à propriedade do imóvel, quando o convênio tiver por objeto a execução de obras ou benfeitorias no imóvel (inciso VIII).

Ainda, estabelece o $\$ \mathbf{1}^{\mathbf{0}}$, na redação que lhe foi conferida pela Instrução Normativa n. 4/2007, que o plano de trabalho será integrado pela:

(...) especificação completa do bem a ser produzido ou adquirido e, no caso de obras, instalaçôes ou serviços, o projeto básico, entendido como tal o conjunto de elementos 
necessários e suficientes para caracterizar, de modo preciso, a obra, instalação ou serviço objeto do convênio, ou nele envolvida, sua viabilidade técnica, custos, fases ou etapas, e prazos de execução, devendo, ainda, conter os elementos discriminados no inciso IX do art. $6^{\circ}$ da Lei n. 8.666, de 21 de junho de 1993, inclusive os referentes à implementação das medidas sugeridas nos estudos ambientais eventualmente exigidos, conforme disposto no art. 12 da Lei n. 6.938, de 31 de agosto de 1981.

Quanto à qualificação dos convenentes, a comprovação de que os entes não se encontram em situação de mora ou inadimplência perante órgão ou entidade da Administração Pública Federal Direta e Indireta pode ser efetuada por meio de certidão emitida pelo Serviço Auxiliar de Informações para Transferências Voluntárias - CAUC (art. $2^{\circ}$, VII e $3^{\circ}$, caput), possibilidade esta reiterada pelo parágrafo único do artigo 61 da Lei Federal n. 12.919/2013:

Art. 61. (...)

Parágrafo único. A demonstração, por parte dos Estados, do Distrito Federal e dos Municípios, do cumprimento das exigências para a realização de transferência voluntária se dará exclusivamente no momento da assinatura do respectivo convênio ou contrato, ou na assinatura dos correspondentes aditamentos de valor, e deverá ser feita por meio de apresentação, ao órgão concedente, de documentação comprobatória da regularidade ou, a critério do beneficiário, de extrato emitido pelo Serviço Auxiliar de Informaçóes para Transferências Voluntárias - CAUC, o qual terá validade mínima de 120 dias, ressalvadas as exigências contidas em Lei Complementar, sendo dispensado para os Municípios inclusos no programa Territórios de Cidadania, conforme Lei n. 12.249, de 11 de junho de 2010, ou por sistema eletrônico de requisitos fiscais que o substitua, disponibilizado pela Secretaria do Tesouro Nacional do Ministério da Fazenda, para os itens nele previstos. (Grifo nosso)

No ano de 2008, foi editada a Portaria Interministerial n. 127, objetivando a veiculação de normas para a execução do disposto no Decreto Federal n. 6.170, de 25 de julho de 2007, que acabou por derrogar algumas disposições da Instrução Normativa n. 1, de 1997, e limitar o seu campo de atuação. Nessa medida, dispôs o artigo 74-B, acrescentado pela Portaria Interministerial n. 342, de 05 de novembro de 2008: "A Instrução Normativa n. 01, de 15 de janeiro de 1997, da Secretaria do Tesouro Nacional, não se aplica aos convênios e contratos de repasse celebrados sob a vigência desta Portaria".

Retratando a evolução normativa das transferências voluntárias, extrai-se trecho de cartilha elaborada pela Advocacia-Geral da União, transcrito em razão da clareza da explanação:

Antes do Decreto n. 6.170/2007, os convênios (que envolviam transferência de recursos) deveriam atender a Instrução Normativa n. 01, de 1997, da Secretaria do Tesouro Nacional. Aos instrumentos de convênio celebrados na vigência da Portaria Interministerial n. 
127, de 29 de maio de 2008 (com as alterações dadas pelas Portarias n. 165, 342, 404, 268, 534 e 23 de 20-06, 05-11 e 23-12-08, 25-08 , 30-12-09 e 19-01-10), não mais se aplica a IN STN n. 1/1997.

A Instrução Normativa n. 1, de 15-01-1997, da Secretaria do Tesouro Nacional, não foi revogada pelo Decreto n. 6.170/2007, e pela Portaria Interministerial n. 127/2008, segundo entendimento firmado pelo TCU no Acórdão 1.937/2008-Plenário, ${ }^{11}$

11 Segue o voto do Min. Relator, Benjamin Zymler: "Consoante registrado no Relatório supra, o Exmo. Sr. Ministro da Defesa, com suporte no comando contido no art. 264 do RI/TCU, indaga a este Tribunal se a Instrução Normativa STN n. 1, de 15 de janeiro de 1997, teria sido revogada pelo Decreto n. 6.170, de 25 de julho de 2007, regulamentado pela Portaria Interministerial MP/MF/ MCT n. 127, de 29 de maio de 2008. Questiona, ainda, sobre possibilidade de continuar utilizando o "pré-convênio" ou "termo simplificado", dado que esses institutos não são mencionados nos citados Decreto e Portaria.

2. Anoto, inicialmente, que o expediente encaminhado pelo Ministro de Estado da Defesa atende aos requisitos de admissibilidade previstos para consulta, consoante demonstrado pela Sra. Analista nos itens 2 e 3 da instrução acima transcrita. Também em relação ao mérito, considero que a Sra Analista explicitou nos itens 4 a 21 de sua instrução os motivos que embasam a conclusão externada pela Unidade Técnica, razão pela qual os incorporo ao presente Voto. A despeito disso, considero conveniente explicitar os aspectos mais relevantes contidos na instrução da Sra, Analista:

I - A IN/STN n. 1/97 ressalta o aspecto relativo à formalização dos instrumentos de transferência de recursos do Orçamento Fiscal e da Seguridade Social da União para a execução de projetos. O Decreto n. 6.170/2007 e a citada Portaria dispóem sobre "a transferência em si, estabelecendo vedações e requisitos para a celebração desses convênios, além de instituir novas modalidades de descentralização de crédito, tais como o "contrato de repasse" e o "termo de cooperação".

II - O Decreto de 2007 instituiu procedimentos como a padronização, "que consiste no estabelecimento de "critérios a serem seguidos nos convênios ou contratos de repasse com o mesmo objeto, definidos pelo concedente ou contratante, especialmente quanto às características do objeto e ao seu custo" (art. $1^{\circ}, \mathbb{S} 1^{\circ}$, inciso XI), ou, ainda, o chamamento público, que, buscando por meio de critérios objetivos selecionar projetos ou entidades que tornem mais eficaz o objeto visado, poderá preceder a celebração de convênio com entidades privadas sem fins lucrativos (art. 40)".

III - Verifica-se, pois, que o referido Decreto e seu regulamento estabeleceram procedimentos com o objetivo de conferir mais transparência ao processo de transferência de recursos da Uniāo por meio de convênios. Esses instrumentos normativos modificaram, também, alguns "conceitos específicos definidos na norma anterior, a exemplo daqueles enunciados no $\$ 1^{\circ}$ do art. $1^{\circ}$ da IN/STN n. 1/97 e reproduzidos nas normas supervenientes".

IV - Nem o citado Decreto, nem aquela a Portaria declaram expressamente a revogação da IN de 1997. Além disso, poucos são os dispositivos que regulam de forma distinta matéria também tratada nessa Instrução Normativa. Houve, portanto, revogação somente de dispositivos específicos cujo objeto foi regulado de forma diversa.

$\mathrm{V}$ - Não se operou, porém, revogação dos $\$ \$ 8^{\circ}$ e $9^{\circ}$ do art. $2^{\circ}$ da IN/STN n. 1/97, que tratam da possibilidade de adoção de pré-projeto; nem do inciso I de seu art. $4^{\circ}$, que cuida da formulação do pré-convênio, quando da apreciação das minutas de convênio pelos setores técnico e 
decisão que encontra explicação no trecho do voto do ministro Relator ao dizer que "Nem o citado Decreto, nem aquela Portaria declaram expressamente a revogação da IN de 1997. Além disso, poucos são os dispositivos que regulam de forma distinta matéria também tratada nessa Instrução Normativa. Houve, portanto, revogação somente de dispositivos específicos cujo objeto foi regulado de forma diversa".

Por óbvio, a aplicação da Instrução Normativa n. 1, de 15-01-1997, da Secretaria do Tesouro Nacional, só terá cabimento quando a matéria não tenha sido regulada de forma diversa pelo Decreto n. 6.170/2007, e pela Portaria Interministerial n. 127/2008, ou quando não for o caso da aplicação destas normas.

(...)

O Decreto n. 6.170, de 25-07-2007, e a Portaria Interministerial n. 127/2008, são dirigidos aos convênios e outros ajustes cuja execução de programas, projetos e atividades de interesse recíproco envolvam transferência de recursos oriundos do Orçamento Fiscal (art. 165, da CF/1988) ${ }^{12}$ e da Seguridade Social da União, salvo as hipóteses que as referidas normas excepcionam, conforme acima elencado. ${ }^{13}$

Após sofrer sucessivas alterações, a Portaria n. 127 foi revogada pela Portaria Interministerial CGU/MF/MP n. 507, de 2011, que constitui atualmente o diploma normativo regulamentador das transferências voluntárias entre os entes da federação. Consoante estabelece o artigo $1^{\circ}$ da mencionada Portaria:

de assessoria jurídica do concedente; também não se operou revogação dos arts. $9^{\circ}$ e 28 , que tratam da formalização de transferências por meio de termo simplificado de convênio (vide transcrição desses comandos normativos no item 18 da citada instrução.

Em face dos exposto, entendo que o expediente do Sr. Ministro de Estado da Defesa deva ser acolhido como consulta. E, quanto ao mérito, considero que lhe deva ser informado que o Decreto n. 6.170, de 2007, regulamentado pela Portaria Interministerial MP/MF/ MCT n. 127, de 2008, não revogou a Instrução Normativa STN n. 1, de 1997. E também que é viável a continuidade da utilização de pré-projeto, pré-convênio ou de termo simplificado, visto que os dispositivos que os regulamenta permanecem em vigência, concomitantemente com as novas disposições que disciplinam outros aspectos da mesma matéria." (BRASIL. Tribunal de Contas da União. Acórdão 1.937/2008-Plenário. Processo 018.449/2008-0. Relator: Ministro Benjamin Zymler. Brasília, 10 set. 2008. Diário Oficial da União, Brasília, 12 set. 2008. Disponível em: http://www2.esporte.gov.br/arquivos/snee/segundoTempo/conveniosTransferencias/acordaoN1937.pdf. Acesso em: $18 \mathrm{dez}$. 2015).

12 Dispõe o art. 165: Leis de iniciativa do poder Executivo estabelecerão: (...)

$\$ 5^{\circ}$. A lei orçamentária anual compreenderá:

I - o orçamento fiscal referente aos Poderes da União, seus fundos, órgãos e entidades da administração direta e indireta, inclusive fundações instituídas e mantidas pelo Poder Público; (...)

13 BRASIL. Advocacia-Geral da União. Cartilha Convênios: extraído do Parecer n. 003/2011/ JCB/CJU-SJC/CGU/AGU. Brasília: Consultoria-Geral da União; São José dos Campos: Consultoria Jurídica da União no Município de São José dos Campos, 2011, p. 11. 
(...) regula os convênios, os contratos de repasse e os termos de cooperação celebrados pelos órgãos e entidades da Administração Pública Federal com órgãos ou entidades públicas ou privadas sem fins lucrativos para a execução de programas, projetos e atividades de interesse recíproco, que envolvam a transferência de recursos financeiros oriundos do Orçamento Fiscal e da Seguridade Social da União.

Identifica-se a aptidão do diploma para a disciplina das transferências voluntárias de recursos, consoante a delimitação veiculada pelo citado artigo $1^{\circ}$. Com vistas a fornecer contornos mais precisos acerca do âmbito de regulamentação da Portaria, estabelece o artigo $2^{\circ}$ as situações não abrangidas por suas normas, destacando-se como primeira exceção à incidência da Portaria os convênios "cuja execução não envolva a transferência de recursos entre os partícipes". Desse modo, a contrario sensu, conclui-se pela aplicabilidade de suas disposições aos convênios que envolvam a transferência de recursos oriundos do Orçamento Fiscal e da Seguridade Social da União, entre as quais as transferências voluntárias de recursos, sem prejuízo das demais exceções veiculadas pelo dispositivo. ${ }^{14}$

14 Dispõe o art. 20: Não se aplicam as exigências desta Portaria:

I - aos convênios:

a) cuja execução não envolva a transferência de recursos entre os partícipes;

b) celebrados anteriormente à data da sua publicação, devendo ser observadas, neste caso, as prescrições normativas vigentes à época da sua celebração, podendo, todavia, se lhes aplicar naquilo que beneficiar a consecução do objeto do convênio;

c) destinados à execução descentralizada de programas federais de atendimento direto ao público, nas áreas de assistência social, médica e educacional, ressalvados os convênios em que for prevista a antecipação de recursos;

d) que tenham por objeto a delegação de competência ou a autorização a órgãos ou entidades de outras esferas de governo para a execução de atribuições determinadas em lei, regulamento ou regimento interno, com geração de receita compartilhada; e

e) homologados pelo Congresso Nacional ou autorizados pelo Senado Federal naquilo em que as disposições dos tratados, acordos e convenções internacionais, específicas, conflitarem com esta Portaria, quando os recursos envolvidos forem integralmente oriundos de fonte externa de financiamento;

II - às transferências celebradas no âmbito:

a) do Programa Federal de Assistência a Vítimas e a Testemunhas Ameaçadas, instituído pela Lei n. 9.807, de 13 de julho de 1999, e regulamentado pelos Decretos n. 3.518, de 20 de junho de 2000, n. 6.044, de 12 de fevereiro de 2007, e n. 6.231, de 11 de outubro de 2007;

b) do Programa Nacional de Alimentação Escolar - PNAE, instituído pela Medida Provisória n. 2.178-36, de 24 de agosto de 2001;

c) do Programa Dinheiro Direto na Escola - PDDE, instituído pela Medida Provisória n. 2.178-36, de 24 de agosto de 2001;

d) do Programa Nacional de Apoio do Transporte Escolar - PNATE, instituído pela Lei n. 10.880, de 9 de junho de 2004; 
Assim como previsto pela Portaria n. 127, de 2008, foram reconhecidas expressamente a vigência e a eficácia da Instrução Normativa n. 1 de 1997, excluídas do seu âmbito de incidência, no entanto, as relações reguladas pela Portaria. Nesse sentido estabelece o artigo 93 do diploma: "A Instrução Normativa n. 01, de 15 de janeiro de 1997, da Secretaria do Tesouro Nacional, não se aplica aos convênios celebrados sob a vigência desta Portaria”.

Dessa forma, os instrumentos legais e normativos que disciplinam as transferências voluntárias abordadas são basicamente, ao lado das disposições da Constituição Federal, da Lei de Responsabilidade Fiscal e do artigo 116 da Lei Federal n. 8.666/93, o Decreto Federal n. 6.170, de 2007, e a Portaria Interministerial n. $507 / 2011$, que apresentam os detalhamentos formais que devem envolver as transferências voluntárias de recursos entre os entes da federação.

\subsubsection{A amplitude da disciplina da Portaria Interministerial n. 507/2011}

Todo o procedimento de transferência de recursos operados por meio de convênios ou contratos de repasse encontra-se atualmente disciplinado pelo Decreto Federal n. 6.170, de 25 de julho de 2007, e pela Portaria Interministerial n. 507, de 24 de novembro de 2011, que regulam desde a divulgação dos programas financiados com recursos disponibilizados pelos órgãos federais, até a efetiva prestação de contas da execução desses programas. Saliente-se, a esse propósito, que a realização

e) do Programa de Apoio aos Sistemas de Ensino para Atendimento de Jovens e Adultos, instituído pela Lei n. 10.880, de 9 de junho de 2004;

f) do Programa Brasil Alfabetizado, instituído pela Lei n. 10.880, de 9 de junho de 2004; e

g) do Programa Nacional de Inclusão de Jovens, instituído pela Lei n. 11.692, de 10 de junho de 2008. III - aos contratos de gestão celebrados com Organizaçôes Sociais - OS, na forma estabelecida pela Lei n. 9.637, de 15 de maio de 1998;

IV - às transferências a que se referem:

a) a Lei n. 10.973, de 2 de dezembro de 2004;

b) o art. $3^{\circ}$ da Lei n. 8.142 , de 28 de dezembro de 1990 ;

c) os arts. 29 e 30 da Lei n. 8.742, de 7 de dezembro de 1993;

d) a Lei n. 12.340, de $1^{\circ}$ de dezembro de 2010 .

$\mathrm{V}$ - a outros casos em que lei específica discipline de forma diversa a transferência de recursos para execução de programas em parceria do Governo Federal com governos estaduais, municipais e do Distrito Federal ou entidade privada sem fins lucrativos;

VI - relativos às transferências formalizadas sob a abrangência da Lei n. 9.807, de 13 de julho de 1999, e dos Decretos n. 3.518, de 20 de junho de 2000, n. 6.044 de 12 de fevereiro de 2007 e n. 6.231, de 11 de outubro de 2007;

VII - às transferências para execução de ações no âmbito do Programa de Aceleração do Crescimento - PAC, regulamentadas pela Lei n. 11.578, de 26 de novembro de 2007, exceto o disposto no Capítulo I do Título I desta Portaria.” 
de todo o procedimento se dá por meio do Sistema de Gestão de Convênios e Contratos de Repasse (SICONV), nos termos do artigo 13 do Decreto n. 6.170, com a redação conferida pelo Decreto Federal n. 6.619, de 2008:

Art. 13. A celebração, a liberação de recursos, o acompanhamento da execução e a prestação de contas de convênios, contratos de repasse e termos de parceria serão registrados no SICONV, que será aberto ao público, via rede mundial de computadores - Internet, por meio de página específica denominada Portal dos Convênios. (Grifo nosso)

No mesmo sentido, disciplina o artigo $3^{\circ}$ da Portaria n. 507/2011:

Art. $3^{\circ}$ Os atos e os procedimentos relativos à formalização, execução, acompanhamento, prestação de contas e informaçóes acerca de tomada de contas especial dos convênios e termos de parceria serão realizados no Sistema de Gestão de Convênios e Contratos de Repasse - SICONV, aberto à consulta pública, por meio do Portal dos Convênios. (Grifo nosso)

Os órgãos e as entidades da Administração Pública federal devem divulgar, por meio do sistema, a relação de programas aptos a serem executados de forma descentralizada, que constitui, assim, o ponto de partida para a apresentação das propostas pelos entes interessados na obtenção dos recursos disponibilizados para a consecução desses programas.

Nessa medida, dispõe o artigo $4^{\circ}$ da mencionada Portaria:

Art. $4^{\circ}$ Os órgãos e entidades da Administração Pública Federal que pretenderem executar programas, projetos e atividades que envolvam transferências de recursos financeiros deverão divulgar anualmente no SICONV a relação dos programas a serem executados de forma descentralizada e, quando couber, critérios para a seleção do convenente.

A divulgação dos programas deve se dar no prazo de 60 dias após a sanção da lei orçamentária, devendo conter, além das especificações relacionadas aos programas disponibilizados, critérios objetivos de elegibilidade e prioridade. Nesse sentido, estabelecem os parágrafos do artigo $4^{\circ}$ :

Art. $4^{\circ}(\ldots)$

$\$ 1^{\circ}$ A relação dos programas de que trata o caput será divulgada em até 60 (sessenta) dias após a sanção da Lei Orçamentária Anual e deverá conter:

I - a descrição dos programas;

II - as exigências, padrões, procedimentos, critérios de elegibilidade e de prioridade, estatísticas e outros elementos que possam auxiliar a avaliação das necessidades locais; e III - tipologias e padrões de custo unitário detalhados, de forma a orientar a celebração dos convênios. 
$\$ 2^{\circ}$ Os critérios de elegibilidade e de prioridade deverão ser estabelecidos de forma objetiva, com base nas diretrizes e objetivos dos respectivos programas, visando atingir melhores resultados na execução do objeto, considerando, entre outros aspectos, a aferição da qualificação técnica e da capacidade operacional do convenente.

$\$ 3^{\circ} \mathrm{O}$ concedente deverá adotar procedimentos claros, objetivos, simplificados e padronizados que orientem os interessados, de modo a facilitar o seu acesso direto aos órgãos da administração pública federal.

Por seu turno, os interessados em obter recursos da União para a execução de ações inseridas nos programas disponibilizados deverão estar credenciados junto ao SICONV para a apresentação de suas respectivas propostas de trabalho, observando os requisitos constantes do artigo 19 da Portaria n. 507/2011. De acordo com o dispositivo, o interessado no recebimento dos recursos disponibilizados deve apresentar: a) a descrição do objeto a ser executado (inciso I); b) a justificativa contendo a caracterização dos interesses recíprocos, a relação entre a proposta e os objetivos e diretrizes do programa, a indicação do público alvo, do problema a ser resolvido e dos resultados esperados (inciso II); c) a estimativa dos recursos financeiros, tanto no tocante ao repasse a ser efetuado quanto à contrapartida, especificando o valor de cada parcela e o montante de todos os recursos (inciso III); d) a previsão de prazo para a execução (inciso IV); e) além das informações relativas à capacidade técnica e gerencial do proponente para a execução do programa (inciso V). A critério do concedente, poderá ser exigido, ainda, prévio cadastramento para o encaminhamento da proposta de trabalho (parágrafo único do artigo 19)..$^{15}$

Ainda na primeira fase de celebração do ajuste, a Portaria veicula uma vasta relação de aspectos concernentes ao plano de trabalho, às condições para a celebração de convênios - previstas num extenso rol de requisitos contidos no artigo 38, que serão objeto de oportuna análise -, e à formalização do instrumento. Ela disciplina também outros pontos essenciais relativos ao procedimento de transferência de recursos, concernentes às diversas fases do ajuste, como a execução do objeto e a correspondente liberação dos recursos, a realização de pagamentos, o acompanhamento e a fiscalização da execução, e a prestação de contas, disciplinando, ainda, as consequências da não apresentação das contas ou de sua não aprovação. Enfim, a matéria é minuciosamente abordada pelo diploma, com todas as suas fases executadas junto ao SICONV, consoante será adiante analisado.

15 Em regra, no entanto, o cadastramento é efetuado após a aceitação da proposta pelo concedente (art. 20, inciso I, $b$ ), sendo realizado junto ao "órgão ou entidade concedente ou nas unidades cadastradoras do Sistema de Cadastro Unificado de Fornecedores - SICAF a ele vinculadas, e terá validade de 1 (um) ano" (art. 21, caput). 


\subsubsection{Transferências voluntárias efetuadas a consórcios públicos}

É possível a realização de transferências voluntárias para entes federados constituídos em consórcios públicos. O consórcio público adquire personalidade jurídica diversa daquela dos entes públicos que o compõem. Pode, assim, assumir personalidade jurídica de direito público, passando a integrar a administração indireta de todos os entes consorciados (art. $6^{\circ}, \$ 1^{\circ}$ da Lei Federal n. 11.107/2005, que dispõe sobre normas gerais de contratação de consórcios públicos). ${ }^{16}$ Por seu turno, conforme definição da própria Lei de Responsabilidade Fiscal, as transferências voluntárias se operam entre as unidades da federação, não abrangendo, desse modo, as entidades da sua administração indireta.

Não obstante a aparente incongruência, a possibilidade de realização de transferências voluntárias aos consórcios públicos é expressamente aventada pelos artigos 13 e seguintes da Portaria Interministerial n. 507/2011, conferindo, inclusive, caráter preferencial aos consórcios:

Art. 13. Os órgãos e entidades da Administração Pública Federal darão preferência às transferências voluntárias para Estados, Distrito Federal e Municípios cujas ações sejam desenvolvidas por intermédio de consórcios públicos, constituídos segundo o disposto na Lei n. 11.107, de 2005.

Art. 14. A celebração do convênio com consórcio público para a transferência de recursos da União está condicionada ao atendimento, pelos entes federativos consorciados, das exigências legais aplicáveis, sendo vedada sua celebração caso exista alguma irregularidade por parte de qualquer dos entes consorciados.

Art. 15. Os Estados, os Municípios e o Distrito Federal poderão executar o objeto do convênio celebrado com a União por meio de consórcio público a que estejam associados.

Parágrafo único. Para efeito do disposto no caput, o convênio poderá indicar o consórcio público como responsável pela execução, sem prejuízo das responsabilidades dos convenentes.

Entretanto, embora os consórcios disponham de personalidade jurídica própria, a celebração de ajuste envolvendo a transferência voluntária de recursos deve observância ao atendimento das exigências aplicáveis aos entes federativos consorciados, considerados individualmente.

16 Dispõe o art. 60: O consórcio público adquirirá personalidade jurídica:

I - de direito público, no caso de constituir associação pública, mediante a vigência das leis de ratificação do protocolo de intenções;

II - de direito privado, mediante o atendimento dos requisitos da legislação civil.

$\$ 1^{\circ} \mathrm{O}$ consórcio público com personalidade jurídica de direito público integra a administração indireta de todos os entes da Federação consorciados. (...) 


\subsection{A DISCIPLINA DAS TRANSFERÊNCIAS VOLUNTÁRIAS PELA LEI DE RESPONSABILIDADE FISCAL}

$\mathrm{Na}$ esfera legal, a Lei de Responsabilidade Fiscal representa, ao lado das leis de diretrizes orçamentárias, o mais relevante diploma regulamentador das transferências voluntárias, sendo responsável, inclusive, pela própria definição do instituto. As transferências voluntárias encontram expressa previsão legal no artigo 25 da Lei de Responsabilidade Fiscal (Lei Complementar n. 101, de 4 de maio de 2000), segundo o qual "entende-se por transferência voluntária a entrega de recursos correntes ou de capital a outro ente da Federação, a título de cooperação, auxílio ou assistência financeira, que não decorra de determinação constitucional, legal ou os destinados ao Sistema Único de Saúde".

O dispositivo estabelece ainda as exigências para a realização de transferências voluntárias, além daquelas trazidas pela lei de diretrizes orçamentárias, assim como a inaplicabilidade das hipóteses de suspensão das transferências às ações de educação, saúde e assistência social:

Art. 25. (...)

$\$ 1^{\circ}$ São exigências para a realização de transferência voluntária, além das estabelecidas na lei de diretrizes orçamentárias:

I - existência de dotação específica;

II - (VETADO)

III - observância do disposto no inciso X do art. 167 da Constituição;

IV - comprovação, por parte do beneficiário, de:

a) que se acha em dia quanto ao pagamento de tributos, empréstimos e financiamentos devidos ao ente transferidor, bem como quanto à prestação de contas de recursos anteriormente dele recebidos;

b) cumprimento dos limites constitucionais relativos à educação e à saúde;

c) observância dos limites das dívidas consolidada e mobiliária, de operações de crédito, inclusive por antecipação de receita, de inscrição em Restos a Pagar e de despesa total com pessoal;

d) previsão orçamentária de contrapartida.

$\$ 2^{\circ}$ É vedada a utilização de recursos transferidos em finalidade diversa da pactuada.

$\$ 3^{0}$ Para fins da aplicação das sanções de suspensão de transferências voluntárias constantes desta Lei Complementar, excetuam-se aquelas relativas a ações de educação, saúde e assistência social.

Ressaltam, então, as seguintes exigências para a realização de transferências voluntárias extraídas da Lei de Responsabilidade Fiscal: 
a) observância dos requisitos estabelecidos pela Lei de Diretrizes Orçamentárias sobre a matéria;

b) existência de dotação específica na lei orçamentária;

c) vedação à utilização dos recursos para pagamento de despesas com pessoal ativo, inativo e pensionistas dos Estados, Distrito Federal e Municípios;

d) comprovação pelo beneficiário da situação de regularidade fiscal e tributária junto ao ente repassador dos recursos, especialmente quanto ao pagamento de tributos, empréstimos e financiamentos, da inexistência de pendências quanto à prestação de contas de recursos já recebidos, além da obediência aos limites constitucionais para gastos com educação e saúde, além daqueles relativos à dívida, despesas com pessoal e restos a pagar;

e) previsão de contrapartida no orçamento do ente beneficiário;

f) necessidade de utilização dos recursos na finalidade previamente estabelecida.

Além do disposto no artigo 25, a Lei de Responsabilidade Fiscal contempla a exigência concernente à previsão e efetiva arrecadação de todos os tributos das competências do ente federado, na forma do parágrafo único de seu artigo 11:

Art. 11. Constituem requisitos essenciais da responsabilidade na gestão fiscal a instituição, previsão e efetiva arrecadação de todos os tributos da competência constitucional do ente da Federação.

Parágrafo único. É vedada a realização de transferências voluntárias para o ente que não observe o disposto no caput, no que se refere aos impostos.

Esmiuçando melhor as exigências, Guilherme Henrique da La Rocque Almeida classifica tais requisitos como requisitos subjetivos para a celebração de convênios, que passam a ser analisados nas seções seguintes.

\subsubsection{Dotação específica do recurso no orçamento do ente convenente}

A exigência quanto à existência de dotação orçamentária específica também é disciplinada pelo artigo 35 da Lei Federal n. 10.180/2001, que organiza e disciplina os Sistemas de Planejamento e de Orçamento Federal, de Administração Financeira Federal, de Contabilidade Federal e de Controle Interno do Poder Executivo Federal, nos seguintes termos:

Art. 35. Os órgãos e as entidades da Administração direta e indireta da União, ao celebrarem compromissos em que haja a previsão de transferências de recursos financeiros, de seus orçamentos, para Estados, Distrito Federal e Municípios, estabelecerão nos instrumentos pactuais a obrigação dos entes recebedores de fazerem incluir tais recursos nos seus respectivos orçamentos. 
$\$ 1^{\circ}$ Ao fixarem os valores a serem transferidos, conforme o disposto neste artigo, os entes nele referidos farão análise de custos, de maneira que o montante de recursos envolvidos na operação seja compatível com o seu objeto, não permitindo a transferência de valores insuficientes para a sua conclusão, nem o excesso que permita uma execução por preços acima dos vigentes no mercado.

$\$ 2^{\circ}$ Os órgãos e as unidades do Sistema de Controle Interno do Poder Executivo Federal zelarão pelo cumprimento do disposto neste artigo, e, nos seus trabalhos de fiscalização, verificarão se o objeto pactuado foi executado obedecendo aos respectivos projeto e plano de trabalho, conforme convencionado, e se a sua utilização obedece à destinação prevista no termo pactual.

$\$ 3^{\circ}$ Os órgãos e as unidades do Sistema de Controle Interno do Poder Executivo Federal, ao desempenhar o seu trabalho, constatando indícios de irregularidades, comunicarão ao Ministro supervisor da unidade gestora ou entidade e aos respectivos órgãos de controle interno e externo dos entes recebedores para que sejam tomadas as providências de suas competências.

$\$ 4^{\circ}$ Quando ocorrer prejuízo à União, os órgãos e as unidades do Sistema de Controle Interno do Poder Executivo Federal adotarão as providências de sua competência, previstas na legislação pertinente, com vistas ao ressarcimento ao erário. (Grifo nosso)

Dessa forma, ao elaborarem suas respectivas propostas orçamentárias, os entes federados devem incluir a previsão de receitas advindas da celebração de convênios não apenas em virtude do princípio da universalidade orçamentária, que determina que todas as receitas e autorização de despesas devam estar contidas na peça orçamentária, mas também como decorrência direta da previsão legal específica, enquanto condição para a celebração do ajuste. A previsão ainda se justifica ante a necessidade de planejamento da atividade governamental. Toda a atividade administrativa necessita ser planejada, e os convênios realizados devem estar inseridos no âmbito das políticas públicas a serem desenvolvidas pelo respectivo ente federado, sendo precedidos de estudos que confirmem a adequação pública da medida preconizada pelo convênio.

A exigência não se restringe apenas ao ente convenente, abrangendo também a necessidade de previsão orçamentária do ente concedente, conforme expressamente previsto no $\$ 10$ do artigo 38 da Portaria Interministerial n. 507/2011:

Art. 38. (...)

$\$ 10$. É condição para a celebração de convênios, a existência de dotação orçamentária específica no orçamento do concedente, a qual deverá ser evidenciada no instrumento, indicando-se a respectiva nota de empenho.

A inclusão da receita e da despesa relativa ao convênio deve constar da proposta orçamentária encaminhada ao Poder Legislativo ou, após aprovação do orçamento, 
em "projeto de lei de crédito adicional para inclusão da receita e despesa no orçamento do próprio ano". ${ }^{17}$

\subsubsection{Impossibilidade de destinação de recursos para o pagamento de despesas com pessoal}

As despesas com pessoal constituem um importante termômetro e parâmetro da sanidade financeira dos entes federados. Uma vez superados os limites fixados legalmente para as despesas com pessoal, o ente deverá proceder às medidas propugnadas pela lei. ${ }^{18}$ Não se admite, dessa forma, que as despesas com pessoal sejam

17 BRASIL. Senado Federal. Manual de obtenção de recursos federais para municípios. 4. ed. Brasília: Senado Federal, 2005, p. 36.

18 A Constituição Federal prevê, nos parágrafos do artigo 169, as medidas a serem adotadas na hipótese de serem ultrapassados os limites legais para a realização de despesas com pessoal: Art. 169. A despesa com pessoal ativo e inativo da União, dos Estados, do Distrito Federal e dos Municípios não poderá exceder os limites estabelecidos em lei complementar.

$\$ 1^{\text {o }}$ A concessão de qualquer vantagem ou aumento de remuneração, a criação de cargos, empregos e funções ou alteração de estrutura de carreiras, bem como a admissão ou contratação de pessoal, a qualquer título, pelos órgãos e entidades da administração direta ou indireta, inclusive fundações instituídas e mantidas pelo poder público, só poderão ser feitas:

I - se houver prévia dotação orçamentária suficiente para atender às projeções de despesa de pessoal e aos acréscimos dela decorrentes;

II - se houver autorização específica na lei de diretrizes orçamentárias, ressalvadas as empresas públicas e as sociedades de economia mista.

$\$ 2^{\circ}$ Decorrido o prazo estabelecido na lei complementar referida neste artigo para a adaptação aos parâmetros ali previstos, serão imediatamente suspensos todos os repasses de verbas federais ou estaduais aos Estados, ao Distrito Federal e aos Municípios que não observarem os referidos limites.

$\$ 3^{\circ}$ Para o cumprimento dos limites estabelecidos com base neste artigo, durante o prazo fixado na lei complementar referida no caput, a União, os Estados, o Distrito Federal e os Municípios adotarão as seguintes providências:

I - redução em pelo menos vinte por cento das despesas com cargos em comissão e funções de confiança;

II - exoneração dos servidores não estáveis.

$\$ 4^{\circ}$ Se as medidas adotadas com base no parágrafo anterior não forem suficientes para assegurar o cumprimento da determinação da lei complementar referida neste artigo, o servidor estável poderá perder o cargo, desde que ato normativo motivado de cada um dos Poderes especifique a atividade funcional, o órgão ou unidade administrativa objeto da redução de pessoal. (...) A Lei de Responsabilidade Fiscal também prevê a adoção de medidas voltadas à redução dos excessos, especialmente veiculadas pelo artigo 23: Art. 23. Se a despesa total com pessoal, do Poder ou órgão referido no art. 20, ultrapassar os limites definidos no mesmo artigo, sem prejuízo das medidas previstas no art. 22, o percentual excedente terá de ser eliminado nos 
custeadas com recursos advindos de outros entes, porque a possibilidade de manter suas despesas correntes, que envolvem o custo da administração, é um ponto central para a autonomia financeira dos entes federados, ao passo que eventuais recursos advindos dos convênios deveriam, em tese, ser destinados justamente à cobertura de despesas de investimentos e de aprimoramento dos serviços postos à disposição da população.

A ressalva é tão importante que a restrição quanto à utilização de recursos advindos de transferências voluntárias para o custeio de despesas com pessoal constitui a única previsão atinente às transferências voluntárias expressamente constante do texto constitucional federal. De acordo com o inciso X do artigo 167, é vedada "a transferência voluntária de recursos e a concessão de empréstimos, inclusive por antecipação de receita, pelos Governos Federal e Estaduais para pagamento de despesas com pessoal ativo, inativo e pensionista, dos Estados, do Distrito Federal e dos Municípios".

$\mathrm{O}$ artigo $23, \$ 3^{\circ}$, da Lei de Responsabilidade Fiscal, por sua vez, determina que uma vez não alcançada a redução das despesas com pessoal no prazo estabelecido, o ente não poderá receber transferências voluntárias:

Art. 23. (...)

$\$ 3^{\circ}$ Não alcançada a redução no prazo estabelecido, e enquanto perdurar o excesso, o ente não poderá:

I - receber transferências voluntárias;

II - obter garantia, direta ou indireta, de outro ente;

III - contratar operações de crédito, ressalvadas as destinadas ao refinanciamento da dívida mobiliária e as que visem à redução das despesas com pessoal. (Grifo nosso)

dois quadrimestres seguintes, sendo pelo menos um terço no primeiro, adotando-se, entre outras, as providências previstas nos $\$ \$ 3^{\circ}$ e $4^{\circ}$ do art. 169 da Constituição.

$\$ 1^{\circ}$ No caso do inciso I do $\$ 3^{\circ}$ do art. 169 da Constituição, o objetivo poderá ser alcançado tanto pela extinção de cargos e funções quanto pela redução dos valores a eles atribuídos.

$\$ 2^{\circ}$ É facultada a redução temporária da jornada de trabalho com adequação dos vencimentos à nova carga horária.

$\$ 3^{\circ}$ Não alcançada a redução no prazo estabelecido, e enquanto perdurar o excesso, o ente não poderá:

I - receber transferências voluntárias;

II - obter garantia, direta ou indireta, de outro ente;

III - contratar operações de crédito, ressalvadas as destinadas ao refinanciamento da dívida mobiliária e as que visem à redução das despesas com pessoal. 


\subsubsection{Comprovação pelo beneficiário de que se acha em dia com o pagamento de tributos, empréstimos e financiamentos devidos ao ente transferidor, bem como quanto à prestação de contas de recursos anteriormente recebidos}

Preceitua o artigo $10 \mathrm{da}$ Portaria Interministerial n. 507/2011, ao dispor sobre as vedações aplicáveis à celebração de convênios:

Art. 10. É vedada a celebração de convênios:

$(\ldots)$

IV - com órgão ou entidade, de direito público ou privado, que esteja em mora, inadimplente com outros convênios celebrados com órgãos ou entidades da Administração Pública Federal, ou irregular em qualquer das exigências desta Portaria; (...)

A inadimplência acarreta como consequência a inclusão do ente faltoso no Cadastro Informativo de Créditos não Quitados do Setor Público Federal (CADIN), nos termos do $\$ 2^{\circ}$ do artigo 10 :

$\$ 2^{\circ}$ Os órgãos e as entidades concedentes procederão, segundo normas próprias e sob sua exclusiva responsabilidade, às inclusões no Cadastro Informativo de Créditos não Quitados do Setor Público Federal - CADIN, de pessoas físicas ou jurídicas que se enquadrem na hipótese prevista no inciso IV do caput, observando-se as normas vigentes a respeito desse cadastro, em especial a Lei n. 10.522, de 19 de julho de 2002.

Convém mencionar ainda a inscrição, no SICONV, do ente inadimplente na apresentação das contas dos recursos recebidos, nos termos do artigo 72 da Portaria n. 507, em especial, de seu $\$ 3^{\circ}$ :

Art. 72. O órgão ou entidade que receber recursos na forma estabelecida nesta Portaria estará sujeito a prestar contas da sua boa e regular aplicação, observando-se o seguinte:

I - o prazo para apresentação das prestaçôes de contas será de ate 60 (sessenta) dias após o encerramento da vigência ou a conclusão da execução do objeto, o que ocorrer primeiro; e

II - o prazo mencionado na alínea anterior constará no convênio.

$\$ 1^{\circ}$ Quando a prestação de contas não for encaminhada no prazo estabelecido no convênio, o concedente estabelecerá o prazo máximo de 30 (trinta) dias para sua apresentação, ou recolhimento dos recursos, incluídos os rendimentos da aplicação no mercado financeiro, atualizados monetariamente e acrescidos de juros de mora, na forma da lei.

$\$ 2^{\circ}$ Para os convênios em que não tenha havido qualquer execução física, nem utilização dos recursos, o recolhimento à conta única do Tesouro deverá ocorrer sem a incidência dos juros de mora.

$\$ 3^{\circ}$ Se, ao término do prazo estabelecido, o convenente não apresentar a prestação de contas nem devolver os recursos nos termos do $\$ 1^{\circ}$, o concedente 
registrará a inadimplência no SICONV por omissão do dever de prestar contas e comunicará o fato ao órgão de contabilidade analítica a que estiver vinculado, para fins de instauraçáo de tomada de contas especial sob aquele argumento e adoção de outras medidas para reparação do dano ao erário, sob pena de responsabilização solidária. (Grifo nosso)

A inscrição no SICONV pode ocorrer também em virtude da não aprovação das contas prestadas, nos termos do artigo $76, \$ 2^{\circ}$ :

Art. 76. A autoridade competente do concedente terá o prazo de noventa dias, contado da data do recebimento, para analisar a prestação de contas do instrumento, com fundamento nos pareceres técnico e financeiro expedidos pelas áreas competentes.

$\$ 1^{\circ} \mathrm{O}$ ato de aprovação da prestação de contas deverá ser registrado no SICONV, cabendo ao concedente prestar declaração expressa de que os recursos transferidos tiveram boa e regular aplicação.

\$ $2^{\circ}$ Caso a prestação de contas não seja aprovada, exauridas todas as providências cabíveis para regularização da pendência ou reparação do dano, a autoridade competente, sob pena de responsabilização solidária, registrará o fato no SICONV e adotará as providências necessárias à instauração da Tomada de Contas Especial, com posterior encaminhamento do processo à unidade setorial de contabilidade a que estiver jurisdicionado para os devidos registros de sua competência. (Grifo nosso)

Contudo, o registro do inadimplente no sistema somente se efetivará para fins de caracterização da vedação ao recebimento de transferências voluntárias após a instauração da tomada de contas especial prevista no artigo 82 da Portaria n. $507 / 2011$. Salienta-se que o registro da inadimplência somente poderá ser efetuado 45 dias após a notificação prévia, conforme o $\$ 6^{\circ}$ do mesmo dispositivo:

Art. 82. A Tomada de Contas Especial é um processo devidamente formalizado, dotado de rito próprio, que objetiva apurar os fatos, identificar os responsáveis e quantificar o dano causado ao Erário, visando ao seu imediato ressarcimento.

$\$ 1^{\circ}$ A Tomada de Contas Especial somente deverá ser instaurada depois de esgotadas as providências administrativas a cargo do concedente pela ocorrência de algum dos seguintes fatos:

I - a prestação de contas do convênio não for apresentada no prazo fixado no inciso I do art. 72, observado o $₫ 1^{\circ}$ do referido artigo desta Portaria; e

II - a prestação de contas do convênio não for aprovada em decorrência de:

a) inexecução total ou parcial do objeto pactuado;

b) desvio de finalidade na aplicação dos recursos transferidos;

c) impugnação de despesas, se realizadas em desacordo com as disposições do termo celebrado ou desta Portaria; 
d) não utilização, total ou parcial, da contrapartida pactuada, na hipótese de não haver sido recolhida na forma prevista no parágrafo único do art. 73 desta Portaria;

e) não utilização, total ou parcial, dos rendimentos da aplicação financeira no objeto do Plano de Trabalho, quando não recolhidos na forma prevista no parágrafo único do art. 73 desta Portaria;

f) inobservância do prescrito no $₫ 1^{\circ}$ do art. 54 desta Portaria ou não devolução de rendimentos de aplicações financeiras, no caso de sua não utilização;

g) não devolução de eventual saldo de recursos federais, apurado na execução do objeto, nos termos do art. 73 desta Portaria; e

h) ausência de documentos exigidos na prestação de contas que comprometa o julgamento da boa e regular aplicação dos recursos.

(...)

\ $3^{\circ}$ A instauração de Tomada de Contas Especial ensejará:

I - a inscrição de inadimplência do respectivo instrumento no SICONV, o que será fator restritivo a novas transferências de recursos financeiros oriundos do Orçamento Fiscal e da Seguridade Social da União mediante convênios, contratos de repasse e termos de cooperação, nos termos do inciso $\mathrm{V}$ do art. 10 desta Portaria; e

II - o registro daqueles identificados como causadores do dano ao erário na conta “DIVERSOS RESPONSÁVEIS” do SIAFI.

(...)

$\$ 6^{\circ} \mathrm{O}$ registro da inadimplência no SICONV só poderá ser realizado 45 dias após a notificação prévia. (Grifo nosso)

Em suma, tanto a inscrição no CADIN, como no SICONV constituem impedimentos para a celebração de convênios e outros ajustes visando ao recebimento de transferências voluntárias, ressalvadas exceções que serão analisadas na seção relativa à suspensão do recebimento de transferências voluntárias.

\subsubsection{Comprovação pelo beneficiário do cumprimento dos limites constitucionais relativos à saúde e educação}

A exigência de comprovação do cumprimento dos limites constitucionais de investimento em saúde e educação decorre da própria relevância conferida pela Constituiçãa Federal a esses direitos. Com efeito, o texto constitucional prevê percentuais mínimos de recursos a serem destinados pelos entes federados às referidas áreas estratégicas da política governamental. A observação de tais limites é retomada pelo artigo 38 da Portaria Interministerial n. 507/2011, ao elencar os requisitos para a celebração de convênios, nos seguintes termos: 
Art. 38. São condições para a celebração de convênios, a serem cumpridas pelo convenente, conforme previsto na Lei Complementar n. 101, de 4 de maio de 2000, na Lei de Diretrizes Orçamentárias e nas demais normas aplicáveis:

(...)

IX - aplicação mínima de recursos na área da Educação, em atendimento ao disposto no art. 212, da Constituição Federal, e no art. $25, \S 1^{\circ}$, inciso IV, alínea $b$, da Lei Complementar n. 101, de 4 de maio de 2000, e que se constitui na aplicação anual, na manutenção e desenvolvimento do ensino, do percentual mínimo de vinte e cinco por cento da receita resultante de impostos, compreendida a proveniente de transferências, cujos dados do exercício encerrado devem ser fornecidos pelo Ente Federativo ao Fundo Nacional de Desenvolvimento da Educação (FNDE), para processamento pelo Sistema de Informações sobre Orçamentos Públicos em Educação (SIOPE), comprovado por meio do seu extrato, com validade até a apresentação dos dados de um novo exercício, limitado às datas de 30 de abril do exercício subsequente, para Municípios, e de 31 de maio do exercício subsequente, para os Estados e para o Distrito Federal, ou, na impossibilidade de verificação por meio desse sistema, apresentação de certidão emitida pelo Tribunal de Contas competente; $\mathrm{X}$ - aplicação mínima de recursos na área da Saúde, em atendimento ao disposto no art. 198, $\$ 2^{\circ}$, da Constituição Federal, no art. 77, do Ato das Disposições Constitucionais Transitórias, nos arts. $6^{\circ}$ e $7^{\circ}$ da Lei Complementar n. 141, de 13 de janeiro e 2012 , e no art. $25, \$ 1$, inciso IV, alínea $b$, da Lei Complementar n. 101, de 4 de maio de 2000, e que se constitui na aplicação anual, em ações e serviços públicos de saúde, dos percentuais mínimos da receita resultante de impostos, compreendida a proveniente de transferências, cujos dados do exercício encerrado devem ser fornecidos pelo Ente Federativo ao Ministério da Saúde (MS), para processamento pelo Sistema de Informações sobre Orçamentos Públicos em Saúde (SIOPS), comprovado por meio do seu extrato, com validade até a apresentação dos dados de um novo exercício, limitado à data de 30 de janeiro do exercício subsequente, ou, na impossibilidade de verificação por meio desse sistema, apresentação de certidão emitida pelo Tribunal de Contas competente; (...) (Grifo nosso)

\subsubsection{Comprovação de observância dos limites das dívidas consolidada e mobiliária, de operações de crédito, inclusive por antecipação de receita, de inscrição em restos a pagar e de despesa total com pessoal}

Os limites das dívidas consolidada e mobiliária dos Estados, do Distrito Federal e dos Municípios são estabelecidos pela Resolução do Senado Federal n. 40, de 2001, decorrente do exercício da competência prevista no artigo 52, incisos VI e IX, da Constituição Federal. Por meio do mencionado instrumento, restaram estabelecidos os seguintes limites: 
Art. 30 A dívida consolidada líquida dos Estados, do Distrito Federal e dos Municípios, ao final do décimo quinto exercício financeiro contado a partir do encerramento do ano de publicação desta Resolução, não poderá exceder, respectivamente, a:

I - no caso dos Estados e do Distrito Federal: 2 (duas) vezes a receita corrente líquida, definida na forma do art. $2^{\circ}$; e

II - no caso dos Municípios: a 1,2 (um inteiro e dois décimos) vezes a receita corrente líquida, definida na forma do art. $2^{\circ}$.

Parágrafo único. Após o prazo a que se refere o caput, a inobservância dos limites estabelecidos em seus incisos I e II sujeitará os entes da Federação às disposições do art. 31 da Lei Complementar n. 101, de 4 de maio de 2000.

Além de estabelecer os limites, a Resolução define os conceitos dos parâmetros nela fixados, apresentando divida pública consolidada como:

montante total, apurado sem duplicidade, das obrigações financeiras, inclusive as decorrentes de emissão de títulos, do Estado, do Distrito Federal ou do Município, assumidas em virtude de leis, contratos, convênios ou tratados e da realização de operaçóes de crédito para amortização em prazo superior a 12 (doze) meses, dos precatórios judiciais emitidos a partir de 5 de maio de 2000 e não pagos durante a execução do orçamento em que houverem sido incluídos, e das operações de crédito, que, embora de prazo inferior a 12 (doze) meses, tenham constado como receitas no orçamento (art. $1^{\circ}, \$ 1^{\circ}$, inciso III).

Conceitua também divida pública mobiliária como "dívida pública representada por títulos emitidos pelos Estados, pelo Distrito Federal ou pelos Municípios" (art. $1^{\circ}, \$ 1^{\circ}$, inciso IV) e divida consolidada líquida como a dívida pública consolidada, deduzidas as disponibilidades de caixa, as aplicações financeiras e os demais haveres financeiros (art. $1^{\circ}, \$ 1^{\circ}$, inciso V).

Por seu turno, os limites das operaçôes de crédito interno e externo dos Estados, do Distrito Federal e dos Municípios, inclusive a concessão de garantias, seus limites e suas condiçôes de autorização, são veiculados pela Resolução do Senado Federal n. 43, de 2001, que também apresenta definiçôes pertinentes aos parâmetros por ela dispostos. Nesse sentido, apenas a título ilustrativo, dispõe o artigo $3^{\circ}$ da Resolução:

Art. $3^{\circ}$ Constitui operação de crédito, para os efeitos desta Resolução, os compromissos assumidos com credores situados no País ou no exterior, em razão de mútuo, abertura de crédito, emissão e aceite de título, aquisição financiada de bens, recebimento antecipado de valores provenientes da venda a termo de bens e serviços, arrendamento mercantil e outras operações assemelhadas, inclusive com o uso de derivativos financeiros.

$\$ 1^{\circ}$ Equiparam-se a operações de crédito: 
I - recebimento antecipado de valores de empresa em que o Poder Público detenha, direta ou indiretamente, a maioria do capital social com direito a voto, salvo lucros e dividendos, na forma da legislação; assunção direta de compromisso, confissão de dívida ou operação assemelhada, com fornecedor de bens, mercadorias ou serviços, mediante emissão, aceite ou aval de títulos de crédito;

II - assunção de obrigação, sem autorização orçamentária, com fornecedores para pagamento a posteriori de bens e serviços.

$\mathrm{O}$ artigo $7^{\mathrm{o}}$ do diploma dispõe sobre os limites propriamente ditos a serem observados pelos entes interessados no recebimento de recursos decorrentes de transferências voluntárias da União:

Art. $7^{\mathbf{0}}$ As operações de crédito interno e externo dos Estados, do Distrito Federal, dos Municípios observarão, ainda, os seguintes limites:

I - o montante global das operações realizadas em um exercício financeiro não poderá ser superior a 16\% (dezesseis por cento) da receita corrente líquida, definida no art. $4^{\circ}$;

II - o comprometimento anual com amortizações, juros e demais encargos da dívida consolidada, inclusive relativos a valores a desembolsar de operaçôes de crédito já contratadas e a contratar, não poderá exceder a 11,5\% (onze inteiros e cinco décimos por cento) da receita corrente líquida;

III - o montante da dívida consolidada não poderá exceder o teto estabelecido pelo Senado Federal, conforme o disposto pela Resolução que fixa o limite global para o montante da dívida consolidada dos Estados, do Distrito Federal e dos Municípios.

\subsubsection{Comprovação da previsão orçamentária de contrapartida}

A contrapartida pode ser definida como a parcela de recursos a serem despendidos pelo ente federado como contribuição para a consecução do objeto de convênio custeado, em grande parte, pelos recursos advindos da transferência voluntária realizada pelo concedente. De acordo com o estabelecido pelo artigo $7^{\circ}$ do Decreto Federal n. 6.170/2007, "a contrapartida do convenente poderá ser atendida por meio de recursos financeiros, de bens e serviços, desde que economicamente mensuráveis".

A comprovação da previsão orçamentária de contrapartida constitui importante requisito para a realização de transferências voluntárias, cujos detalhamentos relativos aos montantes devidos são regulados por meio da Lei de Diretrizes Orçamentárias. Consoante previsto no artigo 24 da Portaria Interministerial n. 507/2011, "a contrapartida, quando houver, será calculada sobre o valor total do objeto e poderá ser atendida por meio de recursos financeiros e de bens ou serviços, se economicamente mensuráveis”. No caso específico dos entes públicos, poderá ser aceita contrapartida não financeira, salvo disposição legal em contrário (art. 24, $\$ 6^{\circ}$ ). Quando ela for financeira, "deverá ser comprovada por meio de previsão 
orçamentária" (art. $24, \$ 5^{\circ}$ ). Nessa hipótese, é necessário que o depósito da contrapartida seja feito na conta específica do convênio (art. $24, \$ 1^{\circ}$ ).

Finalmente, menciona-se a dispensa de contrapartida para as obras com recursos do orçamento da União provenientes do Programa de Aceleração do Crescimento (PAC), inovação trazida no âmbito desse programa em relação às transferências voluntárias.

\subsubsection{Instituição, previsão e arrecadação de todos os tributos de sua competência constitucional}

Ainda no tocante à disciplina legal das transferências voluntárias trazida pela Lei de Responsabilidade Fiscal, faz-se mister mencionar o disposto em seu artigo 11, particularmente quanto à vedação de transferências voluntárias aos entes que não efetivem a arrecadação de todos os impostos previstos na Constituição:

Art. 11. Constituem requisitos essenciais da responsabilidade na gestão fiscal a instituição, previsão e efetiva arrecadação de todos os tributos da competência constitucional do ente da Federação.

Parágrafo único. É vedada a realização de transferências voluntárias para o ente que não observe o disposto no caput, no que se refere aos impostos.

A previsão de sanção contra a inobservância do disposto no caput do artigo 11 suscita questionamentos quanto à eventual inconstitucionalidade da regra. Para Diones Gomes da Rocha, por exemplo, o exercício da competência tributária não é compulsório. Aponta como exemplo emblemático o Imposto Sobre Grandes Fortunas, cuja omissão na instituição não acarretou consequências para o governo federal até os dias atuais. Conforme aponta o autor:

Previsão de tributos implica estudos técnicos especializados para projetar o contingente de contribuintes em potencial, dimensionar o momento adequado para a realização de sua receita. Implica, também, a avaliação do desempenho da máquina administrativa para eficiente fiscalização e arrecadação tributária. Às vezes, falhas no mecanismo de previsão têm sido as responsáveis pela superestimação de receitas, responsável pelo déficit orçamentário. ${ }^{19}$

Sob tal perspectiva, em razão do caráter facultativo do exercício da competência tributária, a imposição de sanção diante da não imposição de todos os impostos de competência do ente culminaria na inconstitucionalidade da previsão.

19 ROCHA, Diones Gomes da. Orçamento público federal, competência tributária e lei de responsabilidade fiscal: estudo sobre a constitucionalidade do artigo 11 da lei de responsabilidade fiscal. 2007. 63f. Monografia (Especialização em Orçamento Público) - Instituto Serzedello Corrêa, Tribunal de Contas da União, Brasília, 2007, p. 51. 
Não obstante aponte para as dificuldades na concretização da sanção, Jair Eduardo Santana sustenta a constitucionalidade do dispositivo: "Defendo, no entanto, que o artigo $145 \mathrm{da} \mathrm{CF},{ }^{20}$ ao utilizar a expressão 'poderão instituir' não pretendeu atribuir uma faculdade ao governante, devendo a interpretação do dispositivo se dar de forma conjunta aos demais artigos que versam sobre as competências dos entes federados". ${ }^{21}$ Nesse sentido, aduz:

Certo é que o legislador constituinte, no art. 145 da CF/88, utilizou a expressão "poderão instituir" (tributos). Mas, isso, por si só, não quer significar que se pretenda atribuir uma faculdade. Mais adiante, limitadamente a impostos, na atribuição da competência a cada ente, nos arts. 153, 155 e 156, utilizou-se do termo "compete à (aos) (...) instituir imposto (s) sobre(...).".22

Prossegue, ainda, o autor:

(...) o Estado não tem o simples poder de tributar, mas o dever de fazê-lo, porquanto não se realizam atividades materiais desejadas pelo povo sem o correspondente recurso financeiro. O raciocínio parece-nos simples. Se o Estado está incumbido de realizar justiça social, erradicar a pobreza, eliminar desigualdades, promover o bem de todos e, enfim, dar a todos certas utilidades e comodidades, por meio genérico da prestação de serviços públicos (em sentido largo), não se poderá admitir raciocínio diverso (....). ${ }^{23}$

Verifica-se, outrossim, que a restrição em questão se refere aos impostos, e não à totalidade dos tributos previstos na Constituição.

A restrição inserida no artigo 11 da Lei de Responsabilidade Fiscal, enquanto consequência da necessidade de instituição de todos os impostos pertencentes ao ente federado, acaba por se constituir em uma medida tendente a evitar que os entes federados, em especial os Municípios, deixem de conferir efetividade à competência tributária

20 Dispõe o art. 145: A União, os Estados, o Distrito Federal e os Municípios poderão instituir os seguintes tributos:

I - impostos;

II - taxas, em razão do exercício do poder de polícia ou pela utilização, efetiva ou potencial, de serviços públicos específicos e divisíveis, prestados ao contribuinte ou postos a sua disposição; III - contribuição de melhoria, decorrente de obras públicas.

$\$ 1^{\circ}$ Sempre que possível, os impostos terão caráter pessoal e serão graduados segundo a capacidade econômica do contribuinte, facultado à administração tributária, especialmente para conferir efetividade a esses objetivos, identificar, respeitados os direitos individuais e nos termos da lei, o patrimônio, os rendimentos e as atividades econômicas do contribuinte.

$\$ 2^{\circ}$ As taxas não poderão ter base de cálculo própria de impostos.

21 SANTANA, Jair Eduardo. Vedação de transferências voluntárias como sanção à renúncia de receitas tributárias. Revista do Tribunal de Contas do Estado de Minas Gerais, v. 2, 2002.

22 SANTANA, Jair Eduardo, cit., p. 102.

23 SANTANA, Jair Eduardo, cit., p. 103. 
que lhes foi atribuída constitucionalmente, tornando-se, assim, totalmente dependentes das transferências intergovernamentais e dos fundos de participação. Essa não instituição dos impostos pode decorrer de uma série de razões, que vão desde o custo de sua imposição até o objetivo de se evitar a adoção de medidas "impopulares", por implicarem em prejuízo aos interesses financeiros da população diretamente interessada e, em consequência, aos próprios interesses eleitorais dos governantes.

Outro importante princípio regente da administração pública que estaria sendo, de certa forma, violado diante da omissão, deliberada ou não, de arrecadação dos impostos de competência do ente, em prejuízo aos interesses da população, seria o princípio da indisponibilidade do interesse público, uma vez que o ente não poderia dispor dos recursos possíveis ao atendimento dos interesses da sociedade como um todo. Assim, se por um lado os interesses da população podem estar sendo aparentemente preservados pela não instituição dos impostos, pode-se afirmar, sob outro ângulo, que esses mesmos interesses estariam sendo violados, na medida em que a unidade federada se privaria dos recursos que decorreriam de uma possível arrecadação.

Finalmente, a comprovação do exercício da plena competência tributária é efetuada "por meio de apresentação de declaração do chefe do executivo de que instituiu, previu e arrecadou os impostos de competência constitucional" e da apresentação "[d] o comprovante de remessa da declaração para o respectivo Tribunal de Contas por meio de recibo do protocolo, aviso de recebimento ou carta registrada”, nos termos do artigo 38, inciso I da Portaria Interministerial n. 507/2011.

\subsection{A SUSPENSÃO DO RECEBIMENTO DE TRANSFERÊNCIAS VOLUNTÁRIAS COMO SANÇÃO PELO DESCUMPRIMENTO DE PRECEITOS DA LEI DE RESPONSABILIDADE FISCAL}

Além da vedação contida no artigo 11, outros dispositivos da Lei de Responsabilidade Fiscal cominam a pena de não recebimento de transferências voluntárias aos entes que deixarem de dar efetividade a seus termos. Com base em tais vedações, pode-se afirmar que as transferências voluntárias podem ser utilizadas como instrumentos de consecução de determinados objetivos, entre os quais destacamos as finalidades abaixo elencadas.

\subsubsection{Suspensão do recebimento de transferências voluntárias como instrumento de controle da despesa total com pessoal}

O ente federado que não cumprir os limites de despesas com pessoal e não adotar as providências necessárias para a eliminação do excedente nos dois quadrimestres 
seguintes, ficará impedido de receber transferências voluntárias, nos termos do artigo $23, \S 3^{\circ}$, inciso I, da Lei de Responsabilidade Fiscal, impedimento que se torna automático se o excesso for verificado no primeiro quadrimestre do último ano do mandato, nos termos do $₫ 4^{\circ}$ :

Art. 23. Se a despesa total com pessoal, do Poder ou órgão referido no art. 20, ultrapassar os limites definidos no mesmo artigo, sem prejuízo das medidas previstas no art. 22, o percentual excedente terá de ser eliminado nos dois quadrimestres seguintes, sendo pelo menos um terço no primeiro, adotando-se, entre outras, as providências previstas nos $\$ \$ 3^{\circ}$ e $4^{\circ}$ do art. 169 da Constituição.

$\$ 1^{\circ}$ No caso do inciso I do $\$ 3^{\circ}$ do art. 169 da Constituição, o objetivo poderá ser alcançado tanto pela extinção de cargos e funçôes quanto pela redução dos valores a eles atribuídos.

$\$ 2^{\circ}$ É facultada a redução temporária da jornada de trabalho com adequação dos vencimentos à nova carga horária.

$\$ 3^{\circ}$ Não alcançada a redução no prazo estabelecido, e enquanto perdurar o excesso, o ente não poderá:

I - receber transferências voluntárias;

II - obter garantia, direta ou indireta, de outro ente;

III - contratar operaçôes de crédito, ressalvadas as destinadas ao refinanciamento da dívida mobiliária e as que visem à redução das despesas com pessoal.

$\$ 4^{\circ}$ As restriçóes do $\$ 3^{\circ}$ aplicam-se imediatamente se a despesa total com pessoal exceder o limite no primeiro quadrimestre do último ano do mandato dos titulares de Poder ou órgão referidos no art. 20. (Grifo nosso)

\subsubsection{Suspensão do recebimento de transferências voluntárias como instrumento de recondução da dívida aos limites}

Aplica-se a suspensão ao recebimento de transferências voluntárias da União e dos Estados aos entes que ultrapassarem os limites da dívida consolidada ao final de um quadrimestre e não a reconduzir aos limites até o término do terceiro quadrimestre subsequente, incidindo imediatamente a restrição quando o excesso se verificar no primeiro quadrimestre do último ano do mandato:

Art. 31. Se a dívida consolidada de um ente da Federação ultrapassar o respectivo limite ao final de um quadrimestre, deverá ser a ele reconduzida até o término dos três subseqüentes, reduzindo o excedente em pelo menos $25 \%$ (vinte e cinco por cento) no primeiro.

$\$ 1^{\circ}$ Enquanto perdurar o excesso, o ente que nele houver incorrido:

I - estará proibido de realizar operação de crédito interna ou externa, inclusive por antecipação de receita, ressalvado o refinanciamento do principal atualizado da dívida mobiliária; 
II - obterá resultado primário necessário à recondução da dívida ao limite, promovendo, entre outras medidas, limitação de empenho, na forma do art. $9^{\circ}$.

$\$ 2^{\circ}$ Vencido o prazo para retorno da dívida ao limite, e enquanto perdurar o excesso, o ente ficará também impedido de receber transferências voluntárias da União ou do Estado.

$\$ 3^{\circ}$ As restriçóes do $\$ 1^{\circ}$ aplicam-se imediatamente se o montante da dívida exceder o limite no primeiro quadrimestre do último ano do mandato do Chefe do Poder Executivo.

$\$ 4^{\circ}$ O Ministério da Fazenda divulgará, mensalmente, a relação dos entes que tenham ultrapassado os limites das dívidas consolidada e mobiliária.

$\$ 5^{\circ}$ As normas deste artigo serão observadas nos casos de descumprimento dos limites da dívida mobiliária e das operações de crédito internas e externas.

\subsubsection{Suspensão do recebimento de transferências voluntárias como sanção pelo não cancelamento da contratação de operação de crédito fora dos limites e condições legais}

Nos termos do art. 33 da Lei de Responsabilidade Fiscal, exige-se a comprovação do atendimento aos limites e condições legais para a contratação de operação de crédito, sob pena de nulidade da operação:

Art. 33. A instituição financeira que contratar operação de crédito com ente da Federação, exceto quando relativa à dívida mobiliária ou à externa, deverá exigir comprovação de que a operação atende às condições e limites estabelecidos.

$\$ 1^{\circ}$ A operação realizada com infração do disposto nesta Lei Complementar será considerada nula, procedendo-se ao seu cancelamento, mediante a devolução do principal, vedados o pagamento de juros e demais encargos financeiros.

$\$ 2^{\circ}$ Se a devolução não for efetuada no exercício de ingresso dos recursos, será consignada reserva específica na lei orçamentária para o exercício seguinte.

$\$ 3^{\circ}$ Enquanto não efetuado o cancelamento, a amortização, ou constituída a reserva, aplicam-se as sançóes previstas nos incisos do $\$ 3^{\circ}$ do art. 23 .

$\$ 4^{\circ}$ Também se constituirá reserva, no montante equivalente ao excesso, se não atendido o disposto no inciso III do art. 167 da Constituição, consideradas as disposições do $\$ 3^{\circ}$ do art. 32. (Grifo nosso)

Observe-se que a contratação de operação de crédito sem a comprovação de que atende às condiçõoes e aos limites estabelecidos por si só não ocasiona a sanção, mas apenas o seu não cancelamento diante da irregularidade, atuando, assim, como uma espécie de "segunda chance" para o saneamento da irregularidade apontada, com possibilidade de futura aplicação das sanções cabíveis, entre as quais a vedação ao recebimento de transferências voluntárias. 


\subsubsection{Suspensão do recebimento de transferências voluntárias como sanção pelo não ressarcimento de dívida honrada por outro ente da federação}

A concessão de garantia pelos entes federados em benefício dos demais é expressamente prevista pelo artigo 40 da Lei de Responsabilidade Fiscal, gerando, dessa forma, a possibilidade de pagamento da dívida pelo ente garantidor, diante da inadimplência do ente federado beneficiário da garantia:

Art. 40. Os entes poderão conceder garantia em operações de crédito internas ou externas, observados o disposto neste artigo, as normas do art. 32 e, no caso da União, também os limites e as condições estabelecidos pelo Senado Federal.

(...)

\$ 90 Quando honrarem dívida de outro ente, em razão de garantia prestada, a Uniáo e os Estados poderáo condicionar as transferências constitucionais ao ressarcimento daquele pagamento.

$\$ 10$. O ente da Federação cuja dívida tiver sido honrada pela União ou por Estado, em decorrência de garantia prestada em operação de crédito, terá suspenso o acesso a novos créditos ou financiamentos até a total liquidação da mencionada dívida. (Grifo nosso)

Conforme estatui o dispositivo, além da possibilidade de condicionar as transferências constitucionais ao pagamento do débito, será suspenso, até a total liquidação da mencionada dívida, o acesso a novos créditos ou financiamentos, incluídos também os créditos decorrentes de transferências voluntárias.

\subsubsection{Suspensão do recebimento de transferências voluntárias como sanção pelo descumprimento dos prazos para remessa das contas do respectivo ente federado}

Buscando conferir efetividade aos reclamos da transparência na gestão dos recursos públicos, a Lei de Responsabilidade Fiscal previu uma série de medidas voltadas à publicidade dos dados concernentes às contas públicas, entre as quais a publicação das contas consolidadas dos entes da federação pelo Poder Executivo da União. Para a consolidação dos dados, os entes subnacionais deverão encaminhar suas informações à União, nos prazos fixados pela própria lei. O descumprimento dessa obrigação acarreta ao ente faltoso a suspensão no recebimento de transferências voluntárias, nos termos do $₫ 2^{\circ}$ do art. 51 da Lei de Responsabilidade Fiscal:

Art. 51. O Poder Executivo da União promoverá, até o dia trinta de junho, a consolidação, nacional e por esfera de governo, das contas dos entes da Federação relativas ao exercício anterior, e a sua divulgação, inclusive por meio eletrônico de acesso público. 
$\$ 1^{\circ}$ Os Estados e os Municípios encaminharão suas contas ao Poder Executivo da União nos seguintes prazos:

I - Municípios, com cópia para o Poder Executivo do respectivo Estado, até trinta de abril;

II - Estados, até trinta e um de maio.

$\$ 2^{\circ} \mathrm{O}$ descumprimento dos prazos previstos neste artigo impedirá, até que a situação seja regularizada, que o ente da Federação receba transferências voluntárias e contrate operaçóes de crédito, exceto as destinadas ao refinanciamento do principal atualizado da dívida mobiliária. (Grifo nosso)

\subsubsection{Suspensão do recebimento de transferências voluntárias como sanção pela não publicação do Relatório Resumido de Execução Orçamentária nos prazos}

Outro instrumento de efetivação da transparência das contas da Administração Pública é o Relatório Resumido da Execução Orçamentária, publicado no prazo de até trinta dias após o encerramento de cada bimestre. O descumprimento dessa obrigação acarreta a suspensão do recebimento de transferências voluntárias pelo ente faltoso até que a situação seja regularizada, nos termos do $\$ 2^{\circ}$ do art. 52 da Lei de Responsabilidade Fiscal:

Art. 52. O relatório a que se refere o $₫ 3^{\circ}$ do art. 165 da Constituição abrangerá todos os Poderes e o Ministério Público, será publicado até trinta dias após o encerramento de cada bimestre e composto de:

(...)

$\$ 2^{\circ} \mathrm{O}$ descumprimento do prazo previsto neste artigo sujeita o ente às sançóes previstas no $\$ 2^{\circ}$ do art. $51 . .^{24-25}$ (Grifo nosso)

24 Dispõe o $\$ 3^{\circ}$ do artigo 165 da CF: $\$ 3^{\circ}$ O Poder Executivo publicará, até trinta dias após o encerramento de cada bimestre, relatório resumido da execução orçamentária.

25 Estabelecem o caput e os $\$ \$ 1^{\circ}$ e $2^{\circ}$ do artigo 51 da LRF: Art. 51. O Poder Executivo da União promoverá, até o dia trinta de junho, a consolidação, nacional e por esfera de governo, das contas dos entes da Federação relativas ao exercício anterior, e a sua divulgação, inclusive por meio eletrônico de acesso público.

$\$ 1^{\circ}$ Os Estados e os Municípios encaminharão suas contas ao Poder Executivo da União nos seguintes prazos:

I - Municípios, com cópia para o Poder Executivo do respectivo Estado, até trinta de abril;

II - Estados, até trinta e um de maio.

$\$ 2^{\circ} \mathrm{O}$ descumprimento dos prazos previstos neste artigo impedirá, até que a situação seja regularizada, que o ente da Federação receba transferências voluntárias e contrate operaçóes de crédito, exceto as destinadas ao refinanciamento do principal atualizado da dívida mobiliária. (Grifo nosso) 


\subsubsection{Suspensão do recebimento de transferências voluntárias como sanção pela não publicação do Relatório de Gestão Fiscal nos prazos estabelecidos em lei}

O Relatório de Gestão Fiscal é mais um documento bastante relevante na publicidade e na transparência da gestão orçamentária, devendo ser elaborado no final de cada quadrimestre pelos titulares de cada um dos Poderes, no prazo de trinta dias após o encerramento do período. $\mathrm{O}$ descumprimento dessa obrigação acarreta a suspensão do recebimento de transferências voluntárias pelo ente faltoso até que a situação seja regularizada, nos termos do $₫ 3^{\circ}$ do art. 55 da Lei de Responsabilidade Fiscal:

Art. 54. Ao final de cada quadrimestre será emitido pelos titulares dos Poderes e órgãos referidos no art. 20 Relatório de Gestão Fiscal, assinado pelo:

I - Chefe do Poder Executivo;

II - Presidente e demais membros da Mesa Diretora ou órgão decisório equivalente, conforme regimentos internos dos órgãos do Poder Legislativo;

III - Presidente de Tribunal e demais membros de Conselho de Administração ou órgão decisório equivalente, conforme regimentos internos dos órgãos do Poder Judiciário;

IV - Chefe do Ministério Público, da União e dos Estados.

Parágrafo único. O relatório também será assinado pelas autoridades responsáveis pela administração financeira e pelo controle interno, bem como por outras definidas por ato próprio de cada Poder ou órgão referido no art. 20.

Art. 55. O relatório conterá:

(...)

$\$ 1^{\circ} \mathrm{O}$ relatório dos titulares dos órgãos mencionados nos incisos II, III e IV do art. 54 conterá apenas as informações relativas à alínea $a$ do inciso I, e os documentos referidos nos incisos II e III.

$\$ 2^{\circ} \mathrm{O}$ relatório será publicado até trinta dias após o encerramento do período a que corresponder, com amplo acesso ao público, inclusive por meio eletrônico.

$\$ 3^{\circ} \mathrm{O}$ descumprimento do prazo a que se refere o $\$ 2^{\circ}$ sujeita o ente à sanção prevista no $\$ 2^{\circ}$ do art. 51 .

$\$ 4^{\circ}$ Os relatórios referidos nos arts. 52 e 54 deverão ser elaborados de forma padronizada, segundo modelos que poderão ser atualizados pelo conselho de que trata o art. 67. (Grifo nosso)

Quanto a este aspecto, indaga-se se o ente federado pode ser penalizado quando o descumprimento se der por parte dos demais Poderes do Estado, e não pelo Chefe do Poder Executivo. Nessa hipótese, ressalta-se a aplicabilidade do raciocínio 
extraído do princípio da intranscendência das sançóes, desenvolvido pela jurisprudência e já reconhecido expressamente pelo Supremo Tribunal Federal, para afastar as restrições impostas pela União para o recebimento de transferências voluntárias pelo ente federado diante do descumprimento dos limites individuais de gastos com pessoal pelo Poder Legislativo e pelo Ministério Público. Nesse sentido, restou assentado em decisão judicial:

(...) O Poder Executivo do Estado do Maranhão não pode sofrer sanções nem expor-se a restrições impostas pela União Federal em tema de realização de operações de crédito, sob a alegação de que o Ministério Público e o Poder Legislativo locais teriam descumprido, cada qual, os limites individuais a eles impostos pela Lei de Responsabilidade Fiscal (art. 20, inciso II, a), pois o Governo do Estado do Maranhão não tem competência para intervir nas esferas orgânicas do Poder Legislativo e do Ministério Público, por se tratar de órgãos investidos de autonomia institucional, por força e efeito de expressa determinação constitucional. Precedentes. ${ }^{26}$

Dessa forma, justifica-se o afastamento da suspensão do recebimento de transferências voluntárias também nesta hipótese, na medida em que carece o Poder Executivo de competência para intervir no âmbito da autonomia conferida aos demais Poderes, a fim de obrigá-los à apresentação dos respectivos Relatórios de Gestão Fiscal.

\subsubsection{Suspensão do recebimento de transferências voluntárias como sanção pela não disponibilização do acesso a informações pormenorizadas referentes às receitas e às despesas nos prazos estabelecidos em lei}

A Lei Complementar n. 131, de 27 de maio de 2009, que acrescentou dispositivos à Lei de Responsabilidade Fiscal, introduziu nova vedação ao recebimento de transferências voluntárias, no tocante aos entes da federação que não confiram transparência à execução financeira e orçamentária nos prazos fixados pela lei. Nesse sentido, estabelece o artigo 73-C da LRF: "O não atendimento, até o encerramento dos prazos previstos no art. 73-B, das determinações contidas nos incisos II e III do parágrafo único do art. 48 e no art. 48-A sujeita o ente à sanção prevista no inciso I do $\$ 3^{\circ}$ do art. $23^{\prime \prime}$.

As determinações contidas no artigo 48, II e III, por sua vez, referem-se, respectivamente, à liberação ao pleno conhecimento e acompanhamento da sociedade, em tempo real, de informaçôes pormenorizadas sobre a execução orçamentária

26 BRASIL. Supremo Tribunal Federal, Tribunal Pleno. Referendo em Medida Cautelar em Ação Civil Originária 1.431 Maranhão. Relator: Ministro Celso de Mello. Brasília, 16 set. 2009. DJe 200, Brasília, 23 out. 2009, p. 8. 
e financeira, em meios eletrônicos de acesso público, e à adoção de sistema integrado de administração financeira e controle, com a disponibilização do acesso a informaçôes pormenorizadas referentes às receitas e às despesas. A lei fixa, ainda, prazos a serem observados pelos entes, cujo descumprimento acarreta a suspensão no recebimento de transferências voluntárias. ${ }^{27}$

Por fim, no tocante às suspensões das transferências voluntárias previstas em lei, convém recordar o disposto no artigo $25, \$ 3^{\circ}$, da LRF, no sentido de que "para fins da aplicação das sanções de suspensão de transferências voluntárias constantes desta Lei Complementar, excetuam-se aquelas relativas a ações de educação, saúde e assistência social".

27 A Lei Complementar n. 131, de 2009, conferiu nova redação ao parágrafo único do artigo 48 e introduziu novos dispositivos à Lei de Responsabilidade Fiscal, nos seguintes termos:

Art. 48. (...)

Parágrafo único. A transparência será assegurada também mediante:

I - incentivo à participação popular e realização de audiências públicas, durante os processos de elaboração e discussão dos planos, lei de diretrizes orçamentárias e orçamentos;

II - liberação ao pleno conhecimento e acompanhamento da sociedade, em tempo real, de informações pormenorizadas sobre a execução orçamentária e financeira, em meios eletrônicos de acesso público;

III - adoção de sistema integrado de administração financeira e controle, que atenda a padrão mínimo de qualidade estabelecido pelo Poder Executivo da União e ao disposto no art. 48-A. Art. 48-A. Para os fins a que se refere o inciso II do parágrafo único do art. 48, os entes da Federação disponibilizarão a qualquer pessoa física ou jurídica o acesso a informações referentes a: I - quanto à despesa: todos os atos praticados pelas unidades gestoras no decorrer da execução da despesa, no momento de sua realização, com a disponibilização mínima dos dados referentes ao número do correspondente processo, ao bem fornecido ou ao serviço prestado, à pessoa física ou jurídica beneficiária do pagamento e, quando for o caso, ao procedimento licitatório realizado;

II - quanto à receita: o lançamento e o recebimento de toda a receita das unidades gestoras, inclusive referente a recursos extraordinários.

Art. 73-A. Qualquer cidadão, partido político, associação ou sindicato é parte legítima para denunciar ao respectivo Tribunal de Contas e ao órgão competente do Ministério Público o descumprimento das prescrições estabelecidas nesta Lei Complementar.

Art. 73-B. Ficam estabelecidos os seguintes prazos para o cumprimento das determinações dispostas nos incisos II e III do parágrafo único do art. 48 e do art. 48-A:

I - 1 (um) ano para a União, os Estados, o Distrito Federal e os Municípios com mais de 100.000 (cem mil) habitantes;

II - 2 (dois) anos para os Municípios que tenham entre 50.000 (cinquenta mil) e 100.000 (cem mil) habitantes;

III - 4 (quatro) anos para os Municípios que tenham até 50.000 (cinquenta mil) habitantes.

Parágrafo único. Os prazos estabelecidos neste artigo serão contados a partir da data de publicação da lei complementar que introduziu os dispositivos referidos no caput deste artigo.

Art. 73-C. O não atendimento, até o encerramento dos prazos previstos no art. 73-B, das determinações contidas nos incisos II e III do parágrafo único do art. 48 e no art. 48-A sujeita o ente à sanção prevista no inciso I do $\$ 3^{\circ}$ do art. 23. 


\subsection{OUTRAS CONDIÇÕES SUBJETIVAS VEICULADAS PELA PORTARIA INTERMINISTERIAL N. 507/2011 E A INSTITUIÇÃO DO CAUC}

Outras condições subjetivas, muitas delas decorrentes de desdobramentos dos requisitos extraídos dos dispositivos da Lei de Responsabilidade Fiscal, são minuciosamente veiculadas pelo artigo 38 da Portaria Interministerial n. 507/2011, consubstanciadas em 18 incisos que visam a demonstrar não apenas a comprovação da regularidade do convenente perante órgão ou entidade da Administração Pública Federal Direta e Indireta, como também concretizar requisitos presentes no próprio texto constitucional, enquanto mecanismos de controle das finanças públicas e de moralização vinculantes a todos os entes da federação.

Os incisos do artigo 38 disciplinam os documentos hábeis a comprovação das seguintes condições a serem cumpridas pelos convenentes:

a) pleno exercício da competência tributária;

b) regularidade previdenciária, atinente à observância dos critérios e das regras gerais para a organização e o funcionamento dos regimes próprios de previdência social dos servidores públicos;

c) regularidade quanto a tributos e contribuiçôes federais e à dívida ativa da União;

d) regularidade quanto a contribuiçōes previdenciárias; ${ }^{28}$

e) regularidade perante o Poder Público Federal, conforme consulta ao Cadastro Informativo dos Créditos não Quitados do Setor Público Federal (CADIN);

f) regularidade quanto a contribuições para o FGTS;

g) regularidade quanto à prestação de contas de recursos federais recebidos anteriormente;

h) regularidade em relação à adimplência financeira em empréstimos e financiamentos concedidos pela União, e administrados pela Secretaria do Tesouro Nacional (STN);

i) aplicação mínima de recursos na área da educação;

j) aplicação mínima de recursos na área da saúde;

k) publicação do Relatório de Gestão Fiscal - RGF;

l) inexistência de vedação ao recebimento de transferência voluntária por descumprimento dos limites de despesa total com pessoal; das dívidas consolidada e mobiliária; de operações de crédito, inclusive por antecipação de receita; e de inscrição em restos a pagar;

28 A exigência vai de encontro ao que estabelece o artigo $195, \$ 3^{\circ}$ da CF: “ $\$ 3^{\circ}$ A pessoa jurídica em débito com o sistema da seguridade social, como estabelecido em lei, não poderá cotratar com o Poder Público nem dele receber benefícios ou incentivos fiscais ou creditícios”. 
m) encaminhamento das contas anuais para a consolidação das contas dos entes da Federação relativas ao exercício anterior;

n) publicação do Relatório Resumido da Execução Orçamentária;

o) comprovação de que as despesas de caráter continuado derivadas do conjunto das parcerias público-privadas já contratadas no ano anterior limitam-se a 3\% (três por cento) da receita corrente líquida do exercício;

p) comprovação da regularidade quanto ao pagamento de precatórios judiciais;

q) comprovação de divulgação da execução orçamentária e financeira por meio eletrônico de acesso ao público e de informações pormenorizadas relativas à receita e à despesa;

r) inexistência de situação de vedação ao recebimento de transferências voluntárias nos termos do art. 33, combinado com o inciso I do $\$ 3^{\circ}$ do art. 23 da Lei de Responsabilidade Fiscal, referentes respectivamente à observância das condições e limites para a realização de operações de crédito e dos limites de despesa com pessoal.

Os incisos são minuciosos na previsão das condições e, ao lado de cada requisito, na forma de sua comprovação. ${ }^{29}$ Diante de tantos detalhes, as leis de diretrizes orça-

29 Dispõe o art. 38: São condições para a celebração de convênios, a serem cumpridas pelo convenente, conforme previsto na Lei Complementar n. 101, de 4 de maio de 2000, na Lei de Diretrizes Orçamentárias e nas demais normas aplicáveis:

I - Demonstração do exercício da Plena Competência Tributária, que se constitui no cumprimento da obrigação de instituir, prever e arrecadar os impostos de competência constitucional do Ente Federativo a que se vincula o convenente, conforme dispõe o parágrafo único do art. 11 da Lei Complementar n. 101, de 4 de maio de 2000, comprovada por meio de apresentação de declaração do chefe do executivo de que instituiu, previu e arrecadou os impostos de competência constitucional, juntamente com o comprovante de remessa da declaração para o respectivo Tribunal de Contas por meio de recibo do protocolo, aviso de recebimento ou carta registrada; com validade até 30 de abril do exercício subseqüente, para os Municípios, e até 31 de maio do exercício subseqüente, para os Estados e para o Distrito Federal;

II - Regularidade Previdenciária, constituída pela observância dos critérios e das regras gerais para a organização e o funcionamento dos regimes próprios de previdência social dos servidores públicos, cujo Certificado de Regularidade Previdenciária - CRP é emitido pela Secretaria de Políticas de Previdência Social - SPPS do Ministério da Previdência Social - MPS, em atendimento ao disposto no art. $7^{\text {o }}$ da Lei n. 9.717, de 27 de novembro de 1998, e no Decreto n. 3.788, de 11 de abril de 2001, sendo válida no prazo e condições da respectiva certidão; III - regularidade quanto a Tributos e Contribuições Federais e à Dívida Ativa da União, conforme dados da Certidáo Conjunta de Débitos relativos a Tributos e Contribuiçóes Federais e à Dívida Ativa da União, fornecida pelos sistemas da Secretaria da Receita Federal do Brasil - RFB e da Procuradoria-Geral da Fazenda Nacional - PGFN, em atendimento ao disposto no art. $25, \$ 1$, inciso IV, alínea $a$, da Lei Complementar n. 101, de 4 de maio de 2000, e art. 27, inciso IV, art. 29 e art. 116 da Lei n. 8.666, de 21 de junho de 1993, sendo válida no prazo e condições da respectiva certidão; 
mentárias da União passaram a contemplar, ao longo dos anos, a possibilidade de toda essa documentação vir a ser substituída por extrato emitido pelo Serviço Auxiliar de Informaçōes para Transferências Voluntárias (CAUC), na forma disposta pelo artigo 78, parágrafo único, da Lei Federal n. 13.242, de 30 de dezembro de 2015,, que dispõe sobre as diretrizes para a elaboração e execução da Lei Orçamentária de 2016:

Art. 78. $\mathrm{O}$ ato de entrega dos recursos a outro ente da Federação, a título de transferência voluntária, nos termos do art. 25 da Lei de Responsabilidade Fiscal, é caracterizado no momento da assinatura do respectivo convênio ou contrato, bem como na assinatura dos correspondentes aditamentos de valor, e não se confunde com as liberações financeiras de recursos, que devem obedecer ao cronograma de desembolso previsto no convênio ou contrato de repasse.

Parágrafo único. A demonstração, por parte dos Estados, do Distrito Federal e dos Municípios, do cumprimento das exigências para a realização de transferência voluntária dar-se-á exclusivamente no momento da assinatura do respectivo convênio ou con-

IV - regularidade quanto a Contribuições Previdenciárias, conforme dados da Certidão Negativa de Débito (CND), fornecida pelo sistema da Secretaria da Receita Federal do Brasil, relativamente às contribuiçôes previdenciárias e às contribuiçôes devidas, por lei, a terceiros, incluindo as inscriçôes em Dívida Ativa do INSS, em atendimento ao disposto no art. 195, $\mathbb{S}$ $3^{\circ}$, da Constituição Federal, e art. $25, \$ 1^{\circ}$, inciso IV, alínea $a$ da Lei Complementar n. 101, de 4 de maio de 2000, sendo válida no prazo e condições da respectiva certidão;

$\mathrm{V}$ - regularidade perante o Poder Público Federal, conforme consulta ao Cadastro Informativo dos Créditos não Quitados do Setor Público Federal (CADIN), cuja verificação da existência de débitos perante os órgãos e entidades do Poder Público Federal atende ao disposto no art. $6^{\circ}$ da Lei n. 10.522, de 19 de julho de 2002, sendo sua comprovação verificada por meio da informação do cadastro mantido no Sistema de Informações do Banco Central do Brasil - SISBACEN, do Banco Central do Brasil (BACEN), e de acordo com os procedimentos da referida Lei;

VI - regularidade quanto a Contribuições para o FGTS, conforme dados do Certificado de Regularidade do Fundo de Garantia do Tempo de Serviço - CRF/FGTS, fornecido pelo Sistema de Controle da Caixa Econômica Federal (CAIXA), cuja comprovação de regularidade, quanto ao depósito das parcelas devidas ao Fundo, atende ao disposto nos arts. 29, inciso IV, e 116 da Lei n. 8.666, de 21 de junho de 1993, e art. 25, inciso IV da Lei Complementar n. 101, de 4 de maio de 2000, sendo válida no prazo e condiçōes do respectivo certificado; VII - regularidade quanto à Prestação de Contas de Recursos Federais Recebidos Anteriormente, em atendimento ao disposto no art. $25, \$ 1^{\circ}$, inciso IV, alínea $a$ da Lei Complementar n. 101, de 4 de maio de 2000, mediante consulta: a) ao Subsistema TRANSFERÊNCIAS do Sistema de Administraçáo Financeira do Governo Federal - SIAFI, da Secretaria do Tesouro Nacional (STN), para os convênios firmados sob a égide da Instrução Normativa STN n. 1, de 15 de janeiro de 1997; b) ao SICONV, para aqueles firmados sob a égide da Portaria Interministerial MP/MF/MCT n. 127, de 2008, dos Ministérios do Planejamento, Orçamento e Gestão, da Fazenda e do Controle e Transparência, e sob a égide desta Portaria; 
trato, ou na assinatura dos correspondentes aditamentos de valor, e deverá ser feita por meio de apresentação, ao órgão concedente, de documentação comprobatória da regularidade ou, a critério do beneficiário, de extrato emitido pelo Serviço Auxiliar de

VIII - regularidade em relação à Adimplência Financeira em Empréstimos e Financiamentos concedidos pela União, e administrados pela Secretaria do Tesouro Nacional (STN), em atendimento ao disposto no art. $25, \$ 1^{\circ}$, inciso IV, alínea $a$, da Lei Complementar n. 101, de 4 de maio de 2000, comprovada mediante informação de adimplência prestada pela STN;

IX - aplicação mínima de recursos na área da Educação, em atendimento ao disposto no art. 212, da Constituição Federal, e no art. $25, \$ 1^{\text {o }}$, inciso IV, alínea $b$, da Lei Complementar n. 101 , de 4 de maio de 2000, e que se constitui na aplicação anual, na manutenção e desenvolvimento do ensino, do percentual mínimo de vinte e cinco por cento da receita resultante de impostos, compreendida a proveniente de transferências, cujos dados do exercício encerrado devem ser fornecidos pelo Ente Federativo ao Fundo Nacional de Desenvolvimento da Educação (FNDE), para processamento pelo Sistema de Informaçôes sobre Orçamentos Públicos em Educação (SIOPE), comprovado por meio do seu extrato, com validade até a apresentação dos dados de um novo exercício, limitado às datas de 30 de abril do exercício subsequente, para Municípios, e de 31 de maio do exercício subsequente, para os Estados e para o Distrito Federal, ou, na impossibilidade de verificação por meio desse sistema, apresentação de certidão emitida pelo Tribunal de Contas competente;

X - aplicação mínima de recursos na área da Saúde, em atendimento ao disposto no art. 198, $\$ 2^{\circ}$, da Constituição Federal, no art. 77, do Ato das Disposiçōes Constitucionais Transitórias, nos arts. $6^{\circ}$ e $7^{\circ}$ da Lei Complementar n. 141, de 13 de janeiro e 2012, e no art. 25, $\$ 1^{\circ}$, inciso IV, alínea $b$, da Lei Complementar n. 101, de 4 de maio de 2000, e que se constitui na aplicação anual, em ações e serviços públicos de saúde, dos percentuais mínimos da receita resultante de impostos, compreendida a proveniente de transferências, cujos dados do exercício encerrado devem ser fornecidos pelo Ente Federativo ao Ministério da Saúde (MS), para processamento pelo Sistema de Informações sobre Orçamentos Públicos em Saúde (SIOPS), comprovado por meio do seu extrato, com validade até a apresentação dos dados de um novo exercício, limitado à data de 30 de janeiro do exercício subsequente, ou, na impossibilidade de verificação por meio desse sistema, apresentação de certidão emitida pelo Tribunal de Contas competente;

XI - publicação do Relatório de Gestão Fiscal - RGF, no prazo de até 30 dias após o encerramento de cada quadrimestre ou semestre, a ser apresentado a gestor de órgão ou entidade concedente, ou ainda à Caixa Econômica Federal (CAIXA), na forma da lei, em atendimento ao disposto nos arts. 54, 55 e 63, inciso II, alínea $b$, da Lei Complementar n. 101, de 4 de maio de 2000, com validade até a data-limite de publicação do Relatório subseqüente, verificada por meio de comprovação de publicação, podendo ser utilizados os relatórios disponíveis no Sistema de Coleta de Dados Contábeis dos Entes da Federação (SIsTN), gerido pela Caixa Econômica Federal (CAIXA) e pela Secretaria do Tesouro Nacional (STN), em regime de cooperação, de cada um dos Poderes e órgãos elencados no art. 20, da Lei Complementar n. 101, de 4 de maio de 2000, ou por meio de declaração do secretário de finanças ou do secretário responsável pela divulgação de informações contábeis e fiscais atestando a publicação dos titulares dos Poderes e órgãos, juntamente com o comprovante de remessa da declaração para o respectivo Tribunal de Contas por meio de recibo do protocolo, aviso de recebimento ou carta registrada; 
Informações para Transferências Voluntárias - CAUC, o qual terá validade mínima de 120 (cento e vinte) dias, ressalvadas as exigências contidas em lei complementar, sendo dispensado para os municípios inclusos no programa Territórios de Cidadania, conforme a Lei n. 12.249, de 11 de junho de 2010, ou por sistema eletrônico de requisitos fiscais que o substitua, disponibilizado pela Secretaria do Tesouro Nacional do Ministério da Fazenda, para os itens nele previstos. (Grifo nosso)

XII - inexistência de vedação ao recebimento de transferência voluntária por descumprimento dos seguintes limites, em atendimento ao disposto no art. $23, \$ 3^{\circ}$, e art. 25 , inciso IV, alínea c, da Lei Complementar n. 101, de 4 de maio de 2000, mediante análise das informaçóes declaradas, de acordo com as orientações previstas no Manual de Demonstrativos Fiscais da Secretaria do Tesouro Nacional, nos Relatórios de Gestão Fiscal (RGF), de cada um dos Poderes e órgãos elencados no art. 20 da Lei Complementar n. 101, de 4 de maio de 2000, disponíveis no Sistema de Coleta de Dados Contábeis dos Entes da Federação (SIsTN), gerido pela Caixa Econômica Federal (CAIXA) e pela Secretaria do Tesouro Nacional (STN), em regime de cooperação, ou entregue pelo Ente Federativo, ou mediante a declaração do secretário de finanças ou do secretário responsável pela divulgação de informaçôes contábeis e fiscais atestando o cumprimento pelos Poderes e órgãos, juntamente com o comprovante de remessa da declaração para o respectivo Tribunal de Contas por meio de recibo do protocolo, aviso de recebimento ou carta registrada; com validade até a data de publicação do RGF subseqüente: a) limites de despesa total com pessoal; constante do Anexo I, do RGF; b) limites das dívidas consolidada e mobiliária; constante do Anexo II, do RGF; c) limite de operaçôes de crédito, inclusive por antecipação de receita; constante do Anexo IV, do RGF; d) limite de inscrição em Restos a Pagar, aplicável para o último ano do mandato, constante do Anexo VI, do RGF. XIII - encaminhamento das Contas Anuais (Demonstrativos Contábeis citados na Lei n. 4.320, de 17 de março de 1964), para a consolidação das contas dos Entes da Federação relativas ao exercício anterior, em atendimento ao disposto no art. 51 da Lei Complementar n. 101, de 4 de maio de 2000, cujo registro é procedido pela própria Secretaria do Tesouro Nacional (STN), com base no Sistema de Coleta de Dados Contábeis dos Entes da Federação (SIsTN), gerido pela Caixa Econômica Federal (CAIXA) e pela STN, em regime de cooperação, o que deverá ocorrer até as datas-limite de 30 de abril do exercício subseqüente, para os Municípios, e de 31 de maio, para Estados ou Distrito Federal, comprovada mediante informação de adimplência prestada pela STN;

XIV - publicação do Relatório Resumido da Execução Orçamentária (RREO), no prazo de até 30 dias após o encerramento de cada bimestre, em atendimento ao disposto nos arts. 52 e 53 da Lei Complementar n. 101, de 4 de maio de 2000, a ser apresentado a gestor de órgão ou entidade concedente, ou ainda à Caixa Econômica Federal (CAIXA), na forma da lei, com validade até a data-limite de publicação do relatório subseqüente, podendo ser utilizado o relatório disponível no Sistema de Coleta de Dados Contábeis dos Entes da Federação (SIsTN), gerido pela Caixa Econômica Federal (CAIXA) e pela Secretaria do Tesouro Nacional (STN), em regime de cooperação, ou a declaração de publicação do secretário de finanças ou do secretário responsável pela divulgação de informaçôes contábeis e fiscais juntamente com a remessa da declaração para o respectivo Tribunal de Contas por meio de recibo do protocolo, aviso de recebimento ou carta registrada; 
O Serviço Auxiliar de Transferências Voluntárias (CAUC) foi instituído pela Instrução Normativa n. 2, de 2 de fevereiro de 2012, da Secretaria do Tesouro Nacional, em substituição ao Cadastro Único do Contribuinte, tendo sido, no entanto, mantida a sigla CAUC. Representa um instrumento de auxílio na verificação do cumprimento dos requisitos fiscais previstos na Portaria n. 507/2011 para o recebimento de transferências voluntárias. Entre os requisitos elencados pela Portaria, treze deles são comprováveis pelo CAUC, a saber:

XV - comprovação de que as Despesas de Caráter Continuado Derivadas do Conjunto das Parcerias Público-Privadas já contratadas no ano anterior limitam-se a 3\% (três por cento) da receita corrente líquida do exercício e se as despesas anuais dos contratos vigentes nos 10 (dez) anos subseqüentes limitam-se a 3\% (três por cento) da receita corrente líquida projetada para os respectivos exercícios, conforme disposto no art. 28, da Lei n. 11.079, de 30 de dezembro de 2004; comprovado por meio de análise do anexo XVII do Relatório Resumido de Execução Orçamentária (RREO) do $6^{\circ}$ bimestre, de acordo com as orientações previstas no Manual de Demonstrativos Fiscais da Secretaria do Tesouro Nacional (STN), ou por meio de declaração de regularidade quanto aos limites estabelecidos na Lei n. 11.079, de 30 de dezembro de 2004, do chefe do executivo ou do secretário de finanças juntamente com a remessa da declaração para o Tribunal de Contas competente por meio de recibo do protocolo, aviso de recebimento ou carta registrada com validade até 30 de janeiro do ano subseqüente; XVI - comprovação da regularidade quanto ao Pagamento de Precatórios Judiciais, segundo regramento aposto na alínea $b$ do inciso IV do $\$ 10$ do art. 97 do Ato das Disposições Constitucionais Transitórias, comprovado por meio de certificado emitido pelo Cadastro de Inadimplentes do Conselho Nacional de Justiça (CEDIN), disponível na Internet, ou por meio de declaração de regularidade quanto ao pagamento de precatórios judiciais do chefe do executivo ou do secretário de finanças juntamente com a remessa da declaração para o Tribunal de Justiça competente por meio de recibo do protocolo, aviso de recebimento ou carta registrada;

XVII - comprovação de divulgação da execução orçamentária e financeira por meio eletrônico de acesso ao público e de informações pormenorizadas relativas à receita e à despesa em atendimento ao disposto no art. 73-C da Lei Complementar n. 101, de 4 de maio de 2000, comprovado por meio de declaração de cumprimento, juntamente com a remessa da declaração para o respectivo Tribunal de Contas por meio de recibo do protocolo, aviso de recebimento ou carta registrada;

XVIII - inexistência de situação de vedação ao recebimento de transferências voluntárias nos termos do art. 33, combinado com o inciso I do $\$ 3^{\circ}$ do art. 23, ambos da Lei Complementar n. 101, de 4 de maio de 2000, comprovado por meio de declaração de que não realizou operação de crédito enquadrada no $\$ 1^{\circ}$ do art. 33 da Lei Complementar n. 101, de 2000, juntamente com o comprovante de remessa da declaraçáo para o respectivo Tribunal de Contas por meio de recibo do protocolo, aviso de recebimento ou carta registrada. (Grifo nosso) 


\section{Quadro 5.2 Requisitos do art. 38 da Portaria n. 507/2011 comprováveis pelo CAUC}

\begin{tabular}{|c|}
\hline $\begin{array}{l}\text { REQUISITOS PARA RECEBIMENTO DE TRANSFERÊNCIAS VOLUNTÁRIAS } \\
\text { PRESENTES ATUALMENTE NO CAUC }\end{array}$ \\
\hline $\begin{array}{l}\text { Exercício da plena competência tributária - item 100; } \\
\text { Regularidade quanto às contribuições ao INSS - item 201; } \\
\text { Certificado de Regularidade Previdenciária (CRP) }{ }^{30} \text { - item 202; } \\
\text { Regularidade junto ao FGTS - item 203; } \\
\text { Regularidade na prestação de contas de convênios - item 204; } \\
\text { Regularidade perante a Fazenda Pública Federal - item 205; } \\
\text { Regularidade no CADIN - item 207; } \\
\text { Regularidade em relação a empréstimos e financiamentos concedidos pela União - item 208; } \\
\text { Aplicação do mínimo constitucional em educação - item 301; } \\
\text { Aplicação do mínimo constitucional em saúde - item 302; } \\
\text { Publicação do Relatório de Gestão Fiscal - item 400; } \\
\text { Encaminhamento das contas anuais - item 501; } \\
\text { Publicação do RREO - item 601. }\end{array}$ \\
\hline
\end{tabular}

Fonte: adaptado de BRASIL. Ministério da Fazenda; Secretaria do Tesouro Nacional; Coordenação Geral de Análise e Informações sobre as Transferências Financeiras Intergovernamentais; Gerência de Acompanhamento das Ações Judiciais referentes às Transferências Intergovernamentais. Matriz de esclarecimentos, argumentos e contra-argumentos para subsidiar a defesa da uniāo - açôes judiciais que envolvem o Cadastro Único de Convênio (CAUC). Brasília: Ministério da Fazenda, [2011-2012?], p. 5.

$\mathrm{O}$ instrumento tem por objetivo simplificar a verificação do atendimento dos requisitos fiscais para a transferência voluntária de recursos, não configurando um cadastro de inadimplentes, e seu uso não é obrigatório. Ao contrário, a opção pelo uso do sistema é do próprio convenente, que pode escolher apresentar os documentos exigidos de outra forma. Nesse sentido, é expresso o $\$ 3^{\circ}$ do artigo 38 da Portaria n. 507/2011:

$\$ 3^{\circ}$ A critério do beneficiário, poderá ser utilizado, para fins do $₫ 1^{\circ}$, extrato emitido por sistema de consulta de requisitos fiscais para recebimento de transferências voluntárias disponibilizado pela Secretaria do Tesouro Nacional, apenas com relação aos requisitos fiscais que estiverem espelhados no referido extrato.

30 Conforme informação extraída da página do CAUC, "a partir de 04/05/2015, o Serviço Auxiliar de Informaçôes para Transferências Voluntárias (CAUC) não exibe mais o item "1.2 Regularidade quanto a Contribuições Previdenciárias", e o item 1.1 passa a ter a redação "Regularidade quanto a Tributos Federais, à Contribuições Previdenciárias e à Dívida Ativa da Uniāo", passando a atestar também a regularidade previdenciária.

Tais alterações se devem às mudanças ocorridas na Certidão de Débitos Relativos a Créditos Tributários Federais e à Dívida Ativa da União, em virtude da edição da Portaria RFB/ PGFN n. 1.751, de 02/10/2014." (BRASIL. Tesouro Nacional. SIAFI - Estados, Distrito Federal e Municípios: Transferências Voluntárias. Portal do Tesouro Nacional. Disponível em: <http:// consulta.tesouro.fazenda.gov.br/transferencias_voluntarias_novosite/mensagem. asp $>$. Acesso em: 13 set. 2015) 
Alguns documentos, no entanto, não são acompanhados pelo CAUC, tais como os limites de despesas com pessoal, as dívidas, o montante das operações de crédito e a inscrição em restos a pagar, conforme elencados pelo artigo 15 da Instrução Normativa n. 2/2012. ${ }^{31}$

\section{Quadro 5.3 Requisitos do art. 38 da Portaria n. 507/2011 não comprováveis pelo CAUC}

\section{REQUISITOS PARA RECEBIMENTO DE TRANSFERÊNCIAS VOLUNTÁRIAS NÃO PRESENTES ATUALMENTE NO CAUC}

Limites das dívidas consolidada e mobiliária;

Limites de operações de crédito, inclusive por antecipação de receita;

Limites de inscrição em restos a pagar;

Limites de despesa total com pessoal;

Limite de despesa comprometidos com as parcerias público-privadas;

Liberação tempestiva dos recursos para pagamento de precatórios;

Transparência da gestão fiscal;

Inexistência de situação de vedação ao recebimento de transferências voluntárias nos termos da Lei Complementar n. 101, de 4 de maio de 2000.

Fonte: adaptado de BRASIL. Ministério da Fazenda; Secretaria do Tesouro Nacional; Coordenação Geral de Análise e Informações sobre as Transferências Financeiras Intergovernamentais; Gerência de Acompanhamento das Ações Judiciais referentes às Transferências Intergovernamentais, cit., p. 167

31 Dispõe o art. 15: Constituem informações fiscais que não se encontram disponíveis no Serviço Auxiliar de que trata esta Instrução Normativa:

I - observância dos limites de despesa total com pessoal, do limites das dívidas consolidada e mobiliária, do limite de operações de crédito, inclusive por antecipação de receita, e do limite de inscrição em Restos a Pagar (aplicável para o último ano do mandato), em atendimento ao disposto no art. $23, \mathbb{3} 3^{\circ}$; art. $25, \mathbb{S} 1^{\circ}$, inciso IV, alínea $c$, da Lei Complementar n. 101, de 2000, e art. 38, inciso XII, da Portaria Interministerial MP/MF/CGU n. 507, de 2011;

II - observância dos limites de despesas comprometidas com as parcerias público-privadas, em atendimento ao art. 28, da Lei n. 11.079, de 30 de dezembro de 2004, e ao art. 38, inciso XV, da Portaria Interministerial MP/MF/CGU n. 507, de 2011;

III - regularidade quanto ao pagamento de precatórios, em atendimento ao art. 97, $\$ 10$, inciso IV, alínea $b$, do Ato das Disposições Constitucionais Transitórias, e art. 38, inciso XVI, da Portaria Interministerial MP/MF/CGU n. 507, de 2011;

IV - observância de exigência de transparência na gestão fiscal, em cumprimento ao art. 73-C, da Lei Complementar n. 101, de 2000, e art. 38, inciso XVII, da Portaria Interministerial MP/MF/CGU n. 507, de 2011;

$\mathrm{V}$ - inexistência de situação de vedação ao recebimento de transferências voluntárias nos termos do art. 33, combinado com o inciso I do $\$ 3^{\circ}$, do art. 23, ambos da Lei Complementar n. 101, de 2000, e art. 38, inciso XVIII, da Portaria Interministerial MP/MF/CGU n. 507, de 2011. 


\subsubsection{Requisito atinente ao pagamento de precatórios}

O artigo 97 do Ato das Disposições Constitucionais Transitórias da Constituição Federal, introduzido pela Emenda Constitucional n. 62, de 2009, passou a exigir como requisito para o recebimento de transferências voluntárias pelos entes da federação a quitação dos precatórios judiciais, na forma contida no seu $₫ 10$, inciso IV, alínea $b$, com a seguinte redação:

Art. 97. Até que seja editada a lei complementar de que trata o $₫ 15$ do art. 100 da Constituição Federal, os Estados, o Distrito Federal e os Municípios que, na data de publicação desta Emenda Constitucional, estejam em mora na quitação de precatórios vencidos, relativos às suas administraçóes direta e indireta, inclusive os emitidos durante o período de vigência do regime especial instituído por este artigo, farão esses pagamentos de acordo com as normas a seguir estabelecidas, sendo inaplicável o disposto no art. 100 desta Constituição Federal, exceto em seus $\$ \$ 2^{\circ}, 3^{\circ}, 9^{\circ}, 10,11,12$, 13 e 14, e sem prejuízo dos acordos de juízos conciliatórios já formalizados na data de promulgação desta Emenda Constitucional.

(...)

$\$ 2^{\circ}$ Para saldar os precatórios, vencidos e a vencer, pelo regime especial, os Estados, o Distrito Federal e os Municípios devedores depositarão mensalmente, em conta especial criada para tal fim, 1/12 (um doze avos) do valor calculado percentualmente sobre as respectivas receitas correntes líquidas, apuradas no segundo mês anterior ao mês de pagamento, sendo que esse percentual, calculado no momento de opção pelo regime e mantido fixo até o final do prazo a que se refere o $\$ 14$ deste artigo, será:

I - para os Estados e para o Distrito Federal:

a) de, no mínimo, 1,5\% (um inteiro e cinco décimos por cento), para os Estados das regiões Norte, Nordeste e Centro-Oeste, além do Distrito Federal, ou cujo estoque de precatórios pendentes das suas administraçôes direta e indireta corresponder a até $35 \%$ (trinta e cinco por cento) do total da receita corrente líquida;

b) de, no mínimo, 2\% (dois por cento), para os Estados das regiões Sul e Sudeste, cujo estoque de precatórios pendentes das suas administraçôes direta e indireta corresponder a mais de $35 \%$ (trinta e cinco por cento) da receita corrente líquida;

II - para Municípios:

a) de, no mínimo, 1\% (um por cento), para Municípios das regiōes Norte, Nordeste e Centro-Oeste, ou cujo estoque de precatórios pendentes das suas administrações direta e indireta corresponder a até 35\% (trinta e cinco por cento) da receita corrente líquida;

b) de, no mínimo, 1,5\% (um inteiro e cinco décimos por cento), para Municípios das regiōes Sul e Sudeste, cujo estoque de precatórios pendentes das suas administrações direta e indireta corresponder a mais de $35 \%$ (trinta e cinco por cento) da receita corrente líquida. 
$\$ 6^{\circ}$ Pelo menos $50 \%$ (cinquenta por cento) dos recursos de que tratam os $\$ \$ 1^{\circ}$ e $2^{\circ}$ deste artigo serão utilizados para pagamento de precatórios em ordem cronológica de apresentação, respeitadas as preferências definidas no $₫ 1^{\circ}$, para os requisitórios do mesmo ano e no $\$ 2^{\circ}$ do art. 100, para requisitórios de todos os anos.

$(\ldots)$

$\$ 10$ No caso de não liberação tempestiva dos recursos de que tratam o inciso II do $\$$ $1^{\circ}$ e os $\$ \$ 2^{\circ}$ e $6^{\circ}$ deste artigo:

$(\ldots)$

IV - enquanto perdurar a omissão, a entidade devedora:

a) não poderá contrair empréstimo externo ou interno;

b) ficará impedida de receber transferências voluntárias; (...) (Grifo nosso)

Contudo, o dispositivo foi julgado inteiramente inconstitucional por decisão do Supremo Tribunal Federal nas Ações Diretas de Inconstitucionalidade ns. 4.357 e 4.425. ${ }^{32} \mathrm{O}$ julgamento interfere diretamente na exigência contida no inciso XVI do artigo 38 da Portaria Interministerial n. 507/2011, segundo o qual:

Art. 38. São condições para a celebração de convênios, a serem cumpridas pelo convenente, conforme previsto na Lei Complementar n. 101, de 4 de maio de 2000, na Lei de Diretrizes Orçamentárias e nas demais normas aplicáveis:

(...)

XVI - comprovação da regularidade quanto ao Pagamento de Precatórios Judiciais, segundo regramento aposto na alínea $b$ do inciso IV do $\$ 10$ do art. 97 do Ato das Disposiçōes Constitucionais Transitórias, comprovado por meio de certificado emitido pelo Cadastro de Inadimplentes do Conselho Nacional de Justiça (CEDIN), disponível na Internet, ou por meio de declaração de regularidade quanto ao pagamento de precatórios judiciais do chefe do executivo ou do secretário de finanças juntamente com a remessa da declaração para o Tribunal de Justiça competente por meio de recibo do protocolo, aviso de recebimento ou carta registrada; (...)

No entanto, os efeitos da decisão foram modulados no sentido de manter parcialmente o regime criado pela emenda pelo período de cinco anos, contados a partir de janeiro de 2016, subsistindo, assim, durante o período, as sanções para o caso de não liberação de recursos. Nesse sentido, restou concluída a questão de ordem:

32 BRASIL. Supremo Tribunal Federal, Tribunal Pleno. Ação Direta de Inconstitucionalidade n. 4.357, Distrito Federal. Relator: Ministro Ayres Britto. Redator para acórdão: Ministro Luiz Fux. Brasília, 14 mar. 2013. DJe 188, Brasília, 26 set. 2014; BRASIL. Supremo Tribunal Federal, Tribunal Pleno. Ação Direta de Inconstitucionalidade n. 4.425, Distrito Federal. Relator: Ministro Ayres Britto. Redator para acórdão: Ministro Luiz Fux. Brasília, 14 mar. 2013. DJe 251, Brasília, 19 dez. 2013. 
Decisão: Concluindo o julgamento, o Tribunal, por maioria e nos termos do voto, ora reajustado, do Ministro Luiz Fux (Relator), resolveu a questão de ordem nos seguintes termos:

1) modular os efeitos para que se dê sobrevida ao regime especial de pagamento de precatórios, instituído pela Emenda Constitucional n. 62/2009, por 5 (cinco) exercícios financeiros a contar de primeiro de janeiro de 2016;

2) conferir eficácia prospectiva à declaração de inconstitucionalidade dos seguintes aspectos da ADI, fixando como marco inicial a data de conclusão do julgamento da presente questão de ordem (25.03.2015) e mantendo-se válidos os precatórios expedidos ou pagos até esta data, a saber:

2.1.) fica mantida a aplicação do índice oficial de remuneração básica da caderneta de poupança (TR), nos termos da Emenda Constitucional n. 62/2009, até 25.03.2015, data após a qual (i) os créditos em precatórios deverão ser corrigidos pelo Índice de Preços ao Consumidor Amplo Especial (IPCA-E) e (ii) os precatórios tributários deverão observar os mesmos critérios pelos quais a Fazenda Pública corrige seus créditos tributários; e

2.2.) ficam resguardados os precatórios expedidos, no âmbito da administração pública federal, com base nos arts. 27 das Leis n. 12.919/2013 e Lei n. 13.080/2015, que fixam o IPCA-E como índice de correção monetária;

3) quanto às formas alternativas de pagamento previstas no regime especial:

3.1) consideram-se válidas as compensações, os leilóes e os pagamentos à vista por ordem crescente de crédito previstos na Emenda Constitucional n. 62/2009, desde que realizados até 25.03 .2015 , data a partir da qual não será possível a quitação de precatórios por tais modalidades;

3.2) fica mantida a possibilidade de realização de acordos diretos, observada a ordem de preferência dos credores e de acordo com lei própria da entidade devedora, com redução máxima de $40 \%$ do valor do crédito atualizado;

4) durante o período fixado no item 1 acima, ficam mantidas a vinculação de percentuais mínimos da receita corrente líquida ao pagamento dos precatórios (art. 97, $\$ 10$, do ADCT), bem como as sanções para o caso de não liberação tempestiva dos recursos destinados ao pagamento de precatórios (art. 97, $\$ 10$, do ADCT);

5) delegação de competência ao Conselho Nacional de Justiça para que considere a apresentação de proposta normativa que discipline (i) a utilização compulsória de $50 \%$ dos recursos da conta de depósitos judiciais tributários para o pagamento de precatórios e (ii) a possibilidade de compensação de precatórios vencidos, próprios ou de terceiros, com o estoque de créditos inscritos em dívida ativa até 25.03.2015, por opção do credor do precatório, e

6) atribuição de competência ao Conselho Nacional de Justiça para que monitore e supervisione o pagamento dos precatórios pelos entes públicos na forma da presente decisão, vencido o Ministro Marco Aurélio, que não modulava os efeitos da decisão, e, em menor extensão, a Ministra Rosa Weber, que fixava como marco inicial a data 
do julgamento da ação direta de inconstitucionalidade. Reajustaram seus votos os Ministros Roberto Barroso, Dias Toffoli e Gilmar Mendes. Presidência do Ministro Ricardo Lewandowski. Plenário, 25.03.2015.33

Ainda no tocante ao requisito concernente aos precatórios, em Ação Originária ajuizada perante o Supremo Tribunal Federal, o Estado do Maranhão questionou a exigência oposta pela União para a celebração de convênio que teria por objeto a construção de uma fábrica de ração para peixes, com fundamento no artigo 38, inciso XVI, da Portaria Interministerial n. 507/2011. Acatando as alegações do autor, o Ministro Ricardo Lewandowski, Presidente em exercício à época da decisão, concedeu medida liminar no sentido de determinar a abstenção da União em exigir do Estado do Maranhão a apresentação de declaração de quitação de precatórios judiciais para celebrar o convênio referente à proposta de trabalho apresentada. $\mathrm{O}$ eminente Ministro decidiu no seguinte sentido:

Ocorre que o art. 97 do ADCT, que dá suporte a essa exigência, foi declarado inconstitucional por este Tribunal por ocasião do julgamento das Ações Diretas ns. 4.357/DF e 4.425/DF. Dessa forma, declarado inconstitucional tal dispositivo e não havendo outra previsão legal de tal exigibilidade, não pode a União exigi-la.

Anoto, nessa linha, que a Lei Complementar n. 101/2000, que estabelece normas de finanças públicas voltadas para a responsabilidade na gestão fiscal e dá outras providências, apresenta os requisitos para formalização de convênios, sem estipular, contudo, a comprovação de regularidade quanto ao pagamento de precatórios judiciais. ${ }^{34}$

Nessa medida, a comprovação da regularidade do pagamento dos precatórios judiciais não é mais exigível enquanto requisito para a celebração de ajustes envolvendo o repasse de recursos financeiros por meio de transferências voluntárias, observada, no entanto, a modulação dos efeitos da decisão, tornando-a aplicável por cinco exercícios financeiros a contar de primeiro de janeiro de 2016.

\subsubsection{Outras condições para a celebração de convênios}

Além do rol de exigências do artigo 38, o artigo 39 veicula outras condições para a celebração de convênios, reiterando a necessidade de: a) cadastro atualizado do convenente no SICONV (inciso I); b) aprovação de Plano de Trabalho (inciso II); c) obtenção de licença ambiental prévia, quando o convênio envolver obras,

33 BRASIL. Supremo Tribunal Federal, Tribunal Pleno. Questão de Ordem na Ação Direta de Inconstitucionalidade n. 4.425 Distrito Federal. Relator: Ministro Luiz Fux. Brasília, 25 mar. 2015. DJe 152, Brasília, 4 ago. 2015. Grifo nosso.

34 BRASIL. Supremo Tribunal Federal, Tribunal Pleno. Medida Cautelar na Ação Cível Originária n. 2.318 Distrito Federal. Relator: Ministro Celso de Mello. Brasília, 20 jan. 2014. DJe 26, Brasília, 7 fev. 2014. 
instalações ou serviços que exijam estudos ambientais, na forma disciplinada pelo Conselho Nacional do Meio Ambiente (CONAMA) (inciso III); e d) comprovação do exercício pleno dos poderes inerentes à propriedade do imóvel, mediante certidão emitida pelo cartório de registro de imóveis competente, quando o convênio tiver por objeto a execução de obras ou benfeitorias no imóvel (inciso IV).

A eficácia do convênio ainda fica subordinada à publicação do extrato no Diário Oficial da União, no prazo de vinte dias após a assinatura do instrumento, conforme disposto no artigo 46:

Art. 46. A eficácia de convênios, acordos, ajustes ou instrumentos congêneres fica condicionada à publicação do respectivo extrato no Diário Oficial da União, que será providenciada pelo concedente, no prazo de até 20 (vinte) dias a contar de sua assinatura.

Parágrafo único. Somente deverão ser publicados no Diário Oficial da União os extratos dos aditivos que alterem o valor ou ampliem a execução do objeto, vedada a alteração da sua natureza, quando houver, respeitado o prazo estabelecido no caput.

Não apenas os atos de celebração do convênio devem ser publicados, mas também todos os demais atos a ele relacionados, tal como estabelece o artigo $47 \mathrm{da}$ Portaria n. 507/2011: "Aos atos de celebração, alteração, liberação de recursos, acompanhamento e fiscalização da execução e a prestação de contas dos convênios será dada publicidade em sítio eletrônico específico denominado Portal dos Convênios". Observa-se, assim, que a grande tônica procedimental dos convênios celebrados se situa na publicidade dos atos e procedimentos praticados e na consequente inclusão, no SICONV, dos documentos produzidos.

\subsection{DA COMUNICAÇÃO À CASA LEGISLATIVA}

Além da previsão contida no artigo 116 da Lei Federal n. 8.666/93, o dever de comunicação do ajuste à Casa Legislativa respectiva é expressamente veiculado pela Portaria Interministerial n. 507/2011, especialmente em seu artigo 48:

Art. 48. O concedente notificará, facultada a comunicação por meio eletrônico, no prazo de até 10 (dez) dias, a celebração do instrumento à Assembleia Legislativa ou à Câmara Legislativa ou à Câmara Municipal do convenente, conforme o caso.

Parágrafo único. No caso de liberação de recursos, o prazo a que se refere o caput será de dois dias úteis.

Verifica-se que a comunicação é efetuada pelo concedente, cabendo ao convenente, por outra via, a comunicação ao conselho local ou à instância de controle social da respectiva área do governo vinculada ao programa:

Art. 49. Os convenentes deverão dar ciência da celebração ao conselho local ou instância de controle social da área vinculada ao programa de governo que originou a transferência, quando houver. 
Parágrafo único. As entidades privadas sem fins lucrativos deverão notificar, se houver, o conselho municipal ou estadual responsável pela respectiva política pública onde será executada a ação.

$\mathrm{O}$ artigo $6^{\circ}$ do mesmo diploma também estabelece como atribuição do convenente, especificamente dos entes municipais e do Distrito Federal, a comunicação aos partidos políticos e sindicatos com sede no Município, com vistas ao incremento do controle social da transferência de recursos:

Art. 6o Ao convenente compete:

(...)

XI - no caso dos entes municipais e do Distrito Federal, notificar os partidos políticos, os sindicatos de trabalhadores e as entidades empresariais com sede no Município ou Distrito Federal quando ocorrer a liberação de recursos financeiros pelo concedente, como forma de incrementar o controle social, em conformidade com a Lei n. 9.452, de 1997, facultada a notificação por meio eletrônico; (...)

A Lei Federal n. 9.452, de 20 de março de 1997, mencionada pelo dispositivo, determina que as Câmaras Municipais sejam obrigatoriamente notificadas da liberação de recursos federais para os respectivos Municípios, obrigando-lhes, ainda, à notificação dos partidos políticos, sindicatos de trabalhadores e entidades empresariais com sede no Município, na forma do disposto em seus artigos $1^{\circ}$ e $2^{\circ} .{ }^{35}$

\subsection{SUSPENSÃO DO RECEBIMENTO DE TRANSFERÊNCIAS VOLUNTÁRIAS ${ }^{36}$}

A medida de suspensão do recebimento de transferências voluntárias decorre da inobservância das regras impostas aos entes convenentes que receberam repasse de recursos financeiros de órgão federado e tiveram seu nome inserido no Cadastro de Inadimplentes.

Além da inclusão de informações relativas ao inadimplemento dos entes convenentes no SICONV, motivado especialmente pela ausência de prestação de con-

35 Dispõem os artigos $1^{\circ}$ e $2^{\circ}$ : Art. $1^{\circ}$ Os órgãos e entidades da administração federal direta e as autarquias, fundaçôes públicas, empresas públicas e sociedades de economia mista federais notificarão as respectivas Câmaras Municipais da liberação de recursos financeiros que tenham efetuado, a qualquer título, para os Municípios, no prazo de dois dias úteis, contado da data da liberação. Art. 2o A Prefeitura do Município beneficiário da liberação de recursos, de que trata $\mathrm{o}$ art. $1^{\circ}$ desta Lei, notificará os partidos políticos, os sindicatos de trabalhadores e as entidades empresariais, com sede no Município, da respectiva liberação, no prazo de dois dias úteis, contado da data de recebimento dos recursos.

36 PAIVA, Adriano Martins de. Suspensão do repasse de transferências voluntárias da União aos Municípios inadimplentes. Debates em Direito Público - Revista de Direito dos Advogados da Uniāo, Brasília, v. 4, n. 4, p. 324-335, 2005. 
tas e do recolhimento dos recursos e pela instauração de tomada de constas especial

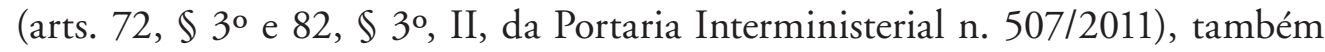
merece menção as informações inseridas no Cadastro Informativo dos Créditos não Quitados de Órgãos e Entidades Federais (CADIN), regulado pela Lei Federal n. 10.522 , de 19 de julho de 2002, cujo artigo $2^{\circ}$ prevê as hipóteses de inclusão de inadimplentes:

Art. 20 O Cadin conterá relação das pessoas físicas e jurídicas que:

I - sejam responsáveis por obrigações pecuniárias vencidas e não pagas, para com órgãos e entidades da Administração Pública Federal, direta e indireta;

II - estejam com a inscrição nos cadastros indicados, do Ministério da Fazenda, em uma das seguintes situações:

a) cancelada no Cadastro de Pessoas Físicas - CPF;

b) declarada inapta perante o Cadastro Geral de Contribuintes - CGC.

A partir da inclusão das pessoas físicas ou jurídicas nos cadastros de inadimplentes, vem a lume a questão relativa à legitimidade da vedação incidente sobre a realização de ajustes com a Administração Pública para a obtenção de recursos financeiros por meio de transferências voluntárias. Com efeito, consoante estabelece o artigo 10, inciso IV, da Portaria Interministerial n. 507/2011, é vedada a celebração de convênios "com órgão ou entidade, de direito público ou privado, que esteja em mora, inadimplente com outros convênios celebrados com órgãos ou entidades da Administração Pública Federal, ou irregular em qualquer das exigências desta Portaria”.

Nesse ponto, especificamente quanto às transferências voluntárias realizadas nos termos do artigo 25 da Lei de Responsabilidade Fiscal, envolvendo estritamente os repasses efetuados entre os entes da federação, surgem entendimentos em sentidos diversos acerca da admissibilidade jurídica da restrição, haja vista que a penalização incide sobre o ente federado - e, consequentemente, sobre sua população - e não propriamente sobre o responsável pela inexecução dos termos do convênio ou do dever de prestar contas ou, ainda, sobre o responsável por apresentar contas posteriormente rejeitadas. A situação se agrava ante o fato de grande parte dos Municípios dependerem efetivamente da transferência de recursos para a consecução de suas obrigações constitucionais, consistentes na realização de políticas públicas de interesse comum, cuja consecução ficaria obstada diante de eventual penalização pelo descumprimento das obrigações decorrentes de convênio anteriormente celebrado, especialmente por parte de gestores já sucedidos em seus mandatos.

A incidência da vedação não se afasta, em princípio, dos preceitos que envolvem a sistemática de contratação e demais ajustes celebrados pelos órgãos da Administra- 
ção Pública. Traçando-se um paralelo com os contratos administrativos, verifica-se a legitimidade do contratante em aplicar sanções ao contratado faltoso. Por sua vez, o artigo 116 da Lei Federal n. 8.666/93 permite a aplicação das disposições concernentes aos contratos aos convênios administrativos, autorizando, assim, não propriamente a imposição de penalidades aos convenentes, mas sim a adoção de providências diante da superveniência de fatos que venham a caracterizar a inadimplência deles quanto aos termos do ajuste a que se encontram vinculados.

Ainda sobre a matéria, merece destaque a aplicação, pelo Supremo Tribunal Federal, do princípio da intranscendência das sanções, que veda a interferência indevida de um Poder na esfera dos demais Poderes e órgãos dotados de autonomia constitucional. Tal princípio foi expressamente consagrado no julgamento da ADI n. 2.238/DF, ocasião em que o Tribunal concluiu pela inconstitucionalidade do artigo $9^{\circ}, \$ 3^{\circ}$, da Lei de Responsabilidade Fiscal, que autorizava a limitação de empenho das despesas dos Poderes Legislativo e Judiciário e do Ministério Público pelo próprio Poder Executivo, quando os Poderes não o fizessem no prazo fixado na lei, por vislumbrar no dispositivo "hipótese de interferência indevida do Poder Executivo nos demais Poderes e no Ministério Público". ${ }^{37}$

Tal princípio tem sido utilizado na fundamentação das decisões judiciais para suspender a inscrição no cadastro de inadimplentes motivada pela inadimplência de ente desvinculado do Poder Executivo e dotado de autonomia. A lógica que serve como vetor da decisão reside justamente na aplicação do mencionado princípio, segundo o qual o ente federado, representado pelo Chefe do Poder Executivo, não pode sofrer as consequências da inadimplência motivada por órgão componente da sua própria estrutura, mas desvinculado do Poder Executivo. Assim, se este não tem a prerrogativa de invadir a esfera de atribuições dos demais Poderes sem vulnerar-lhes sua autonomia, pela lógica inversa não seria legítima a limitação sofrida no pleno exercício de suas prerrogativas por ato desidioso ou faltoso atribuído a outra esfera de poder autônomo.

Nesse sentido, reconhecendo a impossibilidade de absorção pelo Poder Executivo das consequências decorrentes da inadimplência praticada pelos demais Poderes dotados de autonomia constitucional, transcreve-se a seguinte ementa:

AÇÃO CÍVEL ORIGINÁRIA - MEDIDA LIMINAR - IMPEDIMENTO À REALIZAÇÃO DE OPERAÇÕES DE CRÉDITO DESTINADAS AO PROGRAMA

37 Dispõe o art. 9o $\$ 3^{\circ}:(\ldots) \$ 3^{\circ}$ No caso de os Poderes Legislativo e Judiciário e o Ministério Público não promoverem a limitação no prazo estabelecido no caput, é o Poder Executivo autorizado a limitar os valores financeiros segundo os critérios fixados pela lei de diretrizes orçamentárias. 
EMERGENCIAL DE FINANCIAMENTO AOS ESTADOS E AO DISTRITO FEDERAL - PEF, AO PROJETO DE MODERNIZAÇÃO DA ADMINISTRAÇÃO DAS RECEITAS E DA GESTÃO FISCAL, FINANCEIRA E PATRIMONIAL DAS ADMINISTRAÇÕES ESTADUAIS - PMAE E AO PROJETO DE FORTALECIMENTO DA GESTÃO FISCAL - PROFIS - RESTRIÇÕES, QUE, EMANADAS DA UNIÃO, INCIDEM SOBRE O ESTADO DO MARANHÃO, POR ALEGADO DESCUMPRIMENTO, POR PARTE DE SEU PODER LEGISLATIVO E DE SEU MINISTÉRIO PÚBLICO, DOS LIMITES SETORIAIS QUE A LEI DE RESPONSABILIDADE FISCAL IMPÓE A TAIS ÓRGÃOS PÚBLICOS (LC N. 101/2000, ART. 20, II, a) - CONFLITO DE INTERESSES ENTRE A UNIÃO E O ESTADO DO MARANHÃO - LITÍGIO QUE SE SUBMETE À ESFERA DE COMPETÊNCIA ORIGINÁRIA DO SUPREMO TRIBUNAL FEDERAL HARMONIA E EQUILÍBRIO NAS RELAÇÕES INSTITUCIONAIS ENTRE O ESTADO DO MARANHÃO E A UNIÃO FEDERAL - O PAPEL DO SUPREMO TRIBUNAL FEDERAL COMO TRIBUNAL DA FEDERAÇÃO - PRETENSÃO CAUTELAR FUNDADA NAS ALEGAÇÔES DE OFENSA AO PRINCÍPIO DA INTRANSCENDÊNCIA DAS MEDIDAS RESTRITIVAS DE DIREITOS MEDIDA CAUTELAR DEFERIDA - DECISÃO DO RELATOR REFERENDADA PELO PLENÁRIO DO SUPREMO TRIBUNAL FEDERAL. CONFLITOS FEDERATIVOS E O PAPEL DO SUPREMO TRIBUNAL FEDERAL COMO TRIBUNAL DA FEDERAÇÃO. (...) O ALTO SIGNIFICADO DA LEI DE RESPONSABILIDADE FISCAL E A QUESTÃO DE SUA APLICABILIDADE AO ESTADO DO MARANHÃO: LIMITE GLOBAL E LIMITES SETORIAIS EM TEMA DE DESPESA COM PESSOAL (PODER LEGISLATIVO E MINISTÉRIO PÚBLICO). - O Poder Executivo do Estado do Maranhão não pode sofrer sanções nem expor-se a restriçóes impostas pela União Federal em tema de realização de operações de crédito, sob a alegação de que o Ministério Público e o Poder Legislativo locais teriam descumprido, cada qual, os limites individuais a eles impostos pela Lei de Responsabilidade Fiscal (art. 20, inciso II, a), pois o Governo do Estado do Maranhão não tem competência para intervir nas esferas orgânicas do Poder Legislativo e do Ministério Público, por se tratar de órgãos investidos de autonomia institucional, por força e efeito de expressa determinação constitucional. Precedentes. ${ }^{38}$

No mesmo sentido, mas fundamentada na impossibilidade de ingerência do Poder Executivo nos demais Poderes, mencione-se a justificativa utilizada para o indeferimento de medida liminar requerida pelo Estado do Piauí e pela Fundação Estadual de Esportes do Piauí para a suspensão da inclusão do Estado nos cadastros de inadimplentes:

Com efeito, se o Poder Executivo não pode interferir na gestão financeira de outros Poderes e órgãos dotados de autonomia constitucional, não é possível, por coerência, estender àquele as consequências por um descumprimento incorrido por estes.

38 BRASIL. Supremo Tribunal Federal, ACO-MC-REF 1.431/MA, cit. 
(...)

Ocorre que, à primeira vista, tal raciocínio se mostra inaplicável aos casos em que o descumprimento das normas de direito financeiro é imputável a entidades com personalidade jurídica de direito público sem o status constitucional de autônomas, como se passa, de forma geral, com autarquias e fundações públicas, de que é exemplo a Fundação Estadual de Esportes do Piauí. Com efeito, tal espécie de entidade se submete à supervisão e ao controle do Chefe da Administração Pública Direta, por força dos quais o ente central da administração pode exercer poderes de ingerência sobre a formulação da política da entidade, na linha do que afirma o art. 84, II, da Constituição Federal, em disposição aplicável por simetria à esfera estadual, ressalvada a possibilidade, de que não se trata in casu, de criação de autarquias com regimes especiais. ${ }^{39}$

Conforme se verifica, a liminar foi negada no caso. No entanto, a contrario sensu, o raciocínio poderia ter sido utilizado para justificar a decisão pela suspensão do cadastro se a atitude faltosa decorresse da atuação de ente dotado de autonomia constitucional, como consequência da aplicação do princípio. Mencionada decisão liminar acabou sendo confirmada no julgamento de Agravo Regimental, cuja ementa segue transcrita:

AGRAVO REGIMENTAL NA AÇÃO CAUTELAR. INSCRIÇÃO DE ENTE FEDERATIVO EM CADASTRO FEDERAL. AUSÊNCIA DE DOCUMENTOS COMPROBATÓRIOS SUFICIENTES A AMPARAR ALEGAÇÕES DA PETIÇÃO INICIAL. PRINCÍPIO DA INTRANSCENDÊNCIA DAS SANÇÓES. INCIDÊNCIA RESTRITA ÀS HIPÓTESES EM QUE PRATICADA A INFRAÇÃO POR ÓRGÃO OU ENTIDADE DOTADOS DE AUTONOMIA CONSTITUCIONAL. PRINCÍPIO DA SEPARAÇÃO DE PODERES (ARTIGO 2º, DA CONSTITUIÇÃO DA REPÚBLICA. MEDIDA LIMINAR INDEFERIDA. AGRAVO REGIMENTAL QUE SE NEGA PROVIMENTO. ${ }^{40}$

Contudo, independentemente do princípio da intranscendência das sanções, o Supremo Tribunal Federal tem se posicionado favoravelmente à exclusão dos entes federados do Cadastro de Inadimplentes ante o claro prejuízo ao atendimento das necessidades e interesses da população. A tendência restou demonstrada em decisão que concedeu tutela antecipada ao Estado do Mato Grosso, que, em sede de Ação Originária, contestou a penalidade imposta ao ente pela União Federal:

SIAFI/CAUC - RISCO DE INCLUSÃO, NESSE CADASTRO FEDERAL, DO ESTADO DE MATO GROSSO - POSSIBILIDADE DE IMPOSIÇÃO, AO ESTADO-MEMBRO, DE LIMITAÇŌES DE ORDEM JURÍDICA, ANTES DO

39 BRASIL. Supremo Tribunal Federal, Decisão Monocrática. Medida Cautelar na Ação Cível Originária n. 2.873 Piauí. Relator: Ministro Luiz Fux. Brasília, 23 set. 2011. DJe 188, Brasília, 29 set. 2011.

40 BRASIL. Supremo Tribunal Federal, Primeira Turma. Agravo Regimental na Medida Cautelar na Ação Cível Originária n. 2.873 Piauí. Relator: Ministro Luiz Fux. Brasília, 28 out. 2014. DJe 225, Brasília, 14 nov. 2014. Grifo nosso. 
JULGAMENTO DE TOMADA DE CONTAS ESPECIAL - REPERCUSSÃO GERAL DA MATÉRIA (RE 607.420-RG/PI, REL. MIN. ROSA WEBER) EXISTÊNCIA DE PLAUSIBILIDADE JURÍDICA - OCORRÊNCIA, NA ESPÉCIE, DE SITUAÇÃO CONFIGURADORA DE "PERICULUM IN MORA" RISCO À CONTINUIDADE DA EXECUÇÃO, NO PLANO LOCAL, DE POLÍTICAS PÚBLICAS - LITÍGIO QUE SE SUBMETE À ESFERA DE COMPETÊNCIA ORIGINÁRIA DO SUPREMO TRIBUNAL FEDERAL - HARMONIA E EQUILÍBRIO NAS RELAÇÕES INSTITUCIONAIS ENTRE OS ESTADOS-MEMBROS E A UNIÃO FEDERAL - O PAPEL DO SUPREMO TRIBUNAL FEDERAL COMO TRIBUNAL DA FEDERAÇÃO - POSSIBILIDADE, NA ESPÉCIE, DE CONFLITO FEDERATIVO - TUTELA ANTECIPATÓRIA DEFERIDA - DECISÃO DO RELATOR REFERENDADA PELO PLENÁRIO DO SUPREMO TRIBUNAL FEDERAL. CONFLITOS FEDERATIVOS E O PAPEL DO SUPREMO TRIBUNAL FEDERAL COMO TRIBUNAL DA FEDERAÇĀO. (...) BLOQUEIO DE RECURSOS FEDERAIS CUJA EFETIVAÇÃO PODE COMPROMETER A EXECUÇÃO, NO ÂMBITO LOCAL, DE PROGRAMA ESTRUTURADO PARA VIABILIZAR A IMPLEMENTAÇÃO DE POLÍTICAS PÚBLICAS. - O Supremo Tribunal Federal, nos casos de inscrição de entidades estatais, de pessoas administrativas ou de empresas governamentais em cadastros de inadimplentes, organizados e mantidos pela União, tem ordenado a liberação e o repasse de verbas federais (ou, então, determinado o afastamento de restriçōes impostas à celebração de operaçôes de crédito em geral ou à obtenção de garantias), sempre com o propósito de neutralizar a ocorrência de risco que possa comprometer, de modo grave e/ou irreversível, a continuidade da execução de políticas públicas ou a prestação de serviços essenciais à coletividade. Precedentes. ${ }^{41}$

A matéria foi objeto de repercussão geral no Supremo Tribunal Federal, suscitada pela Ministra Ellen Gracie no julgamento do Recurso Especial 607.420-RG/PI, especialmente quanto à necessidade de prévio julgamento de Tomada de Contas Especial como requisito para a inclusão do ente federado faltoso no SIAFI. A Ministra considerou que a matéria possui relevância do ponto de vista econômico, político, social e jurídico, alcançando, outrossim, grande número de Estados e Municípios passíveis de sofrerem a suspensão de transferências voluntárias de recursos federais. ${ }^{42}$ Tal recurso foi interposto contra julgado do Tribunal Regional da $1^{\text {a }}$ Região que considerou que a inclusão do ente no cadastro de inadimplentes previamente ao julgamento da TCE iria de encontro ao princípio do devido processo administrativo, entendendo, além disso,

41 BRASIL. Supremo Tribunal Federal, Tribunal Pleno. Referendo em Tutela Antecipada na Ação Cível Originária 2.131 Mato Grosso. Relator: Ministro Celso de Mello. Brasília, 18 abr. 2013. DJe 93, Brasília, 17 maio 2013. Grifo nosso.

42 BRASIL. Supremo Tribunal Federal, Tribunal Pleno. Referendo em Tutela Antecipada na Ação Cível Originária 2.131 Mato Grosso. Relator: Ministro Celso de Mello. Brasília, 18 abr. 2013. DJe 93, Brasília, 17 maio 2013. Repercussão Geral em Recurso Extraordinário 607.420 Piauí. Relatora: Ministra Ellen Gracie. Brasília, 21 out. 2010. DJe 224, Brasília, 23 nov. 2010. 
correta a inclusão do Prefeito no cadastro, e não do ente federado, por ser ele o responsável por eventual ausência ou rejeição da prestação de contas.

\subsection{DA APLICAÇÃO FINANCEIRA DOS RECURSOS}

Os recursos destinados ao cumprimento do ajuste deverão ser depositados em conta específica, tanto aqueles repassados pelo concedente, quanto os oriundos do convenente a título de contrapartida.

Enquanto não empregados em sua finalidade, os recursos deverão ser aplicados no mercado financeiro - se a previsão de uso for igual ou superior a um mês, deverão ser aplicados em caderneta de poupança; se em prazo inferior, em fundo de aplicação financeira de curto prazo. Os rendimentos deverão ser revertidos exclusivamente ao objeto do convênio, não podendo complementar a parcela de contribuição de qualquer das partes, e a realização de saques somente poderá se efetuar se destinada exclusivamente ao pagamento de despesas previstas no ajuste.

A necessidade de aplicação dos recursos advém expressamente do artigo 116, $\$ 4^{\circ}$, da Lei de Licitações (Lei Federal n. 8.666/93), ${ }^{43}$ bem como do artigo 10 , $\$ \$ 4^{\circ}$ e $5^{\circ}$, do Decreto Federal n. 6.170/2007. ${ }^{44}$ No mesmo sentido, estatui o artigo 54 da Portaria Interministerial n. 507/2011:

Art. 54. A liberação de recursos obedecerá ao cronograma de desembolso previsto no Plano de Trabalho e guardará consonância com as metas e fases ou etapas de execução do objeto do instrumento.

43 Dispõem os $\$ \$ 4^{\circ}$ e $5^{\circ}$ do art. 116: (...) $\$ 4^{\circ}$ Os saldos de convênio, enquanto não utilizados, serão obrigatoriamente aplicados em cadernetas de poupança de instituição financeira oficial se a previsão de seu uso for igual ou superior a um mês, ou em fundo de aplicação financeira de curto prazo ou operação de mercado aberto lastreada em títulos da dívida pública, quando a utilização dos mesmos verificar-se em prazos menores que um mês.

$\$ 5^{\circ}$ As receitas financeiras auferidas na forma do parágrafo anterior serão obrigatoriamente computadas a crédito do convênio e aplicadas, exclusivamente, no objeto de sua finalidade, devendo constar de demonstrativo específico que integrará as prestações de contas do ajuste.

Dispõe o caput e os $\$ \$ 4^{\circ}$ e $5^{\circ}$ do artigo 10: Art. 10. As transferências financeiras para órgãos públicos e entidades públicas e privadas, decorrentes da celebração de convênios e contratos de repasse, serão feitas exclusivamente por intermédio de instituição financeira oficial, federal ou estadual, que poderá atuar como mandatária da Uniāo para execução e fiscalização.

(...)

$\$ 4^{\circ}$ Os recursos de convênio, enquanto não utilizados, serão obrigatoriamente aplicados em cadernetas de poupança de instituição financeira pública federal se a previsão de seu uso for igual ou superior a um mês, ou em fundo de aplicação financeira de curto prazo ou operação de mercado aberto lastreada em títulos da dívida pública, quando a utilização desses recursos verificar-se em prazos menores que um mês.

$\$ 5^{\circ}$ As receitas financeiras auferidas na forma do $\$ 4^{\circ}$ serão obrigatoriamente computadas a crédito do convênio e aplicadas, exclusivamente, no objeto de sua finalidade, observado o parágrafo único do art. 12. 
$\$ 1^{\circ}$ Os recursos serão depositados e geridos na conta bancária específica do convênio exclusivamente em instituições financeiras controladas pela União e, enquanto não empregados na sua finalidade, serão obrigatoriamente aplicados:

I - em caderneta de poupança de instituição financeira pública federal, se a previsão de seu uso for igual ou superior a um mês; e

II - em fundo de aplicação financeira de curto prazo, ou operação de mercado aberto lastreada em título da dívida pública, quando sua utilização estiver prevista para prazos menores;

$\$ 2^{\circ}$ Os rendimentos das aplicações financeiras somente poderão ser aplicados no objeto do convênio, estando sujeitos às mesmas condições de prestação de contas exigidas para os recursos transferidos.

$\$ 3^{0}$ As receitas oriundas dos rendimentos da aplicação no mercado financeiro não poderão ser computadas como contrapartida devida pelo convenente.

$\$ 4^{\circ}$ As contas referidas no $\$ 1^{\circ}$ serão isentas da cobrança de tarifas bancárias.

Se o saldo das aplicações for positivo, consoante já salientado, as receitas auferidas serão revertidas a crédito do convênio. Se houver saldo de recursos a serem devolvidos por ocasião da prestação de contas, as receitas advindas das aplicações serão computadas para devolução proporcionalmente aos recursos despendidos pelo concedente e pelo convenente.

De outra sorte, muito embora pouco provável, é possível que o resultado das aplicações de fundo de curto prazo seja negativo, diminuindo os recursos do convênio. Se a aplicação de recursos que resultou em diminuição dos valores entregues para a consecução do objeto do convênio foi efetuada em decorrência de mandamento legal, a solução mais justa aponta para que ambas as partes arquem com o prejuízo, mediante reposição dos valores necessários, proporcionalmente à participação de cada parte no ajuste.

Ressalta-se, ainda, a necessidade de abertura de uma conta bancária específica para cada convênio, como forma de conferir uma maior eficácia no controle e fiscalização em sua execução.

No tocante à liberação dos recursos, é necessário observar o disposto no artigo $116, \$ 3^{\circ}$ da Lei Federal n. 8.666/93:

$\$ 3^{\circ}$ As parcelas do convênio serão liberadas em estrita conformidade com o plano de aplicação aprovado, exceto nos casos a seguir, em que as mesmas ficarão retidas até o saneamento das impropriedades ocorrentes:

I - quando não tiver havido comprovação da boa e regular aplicação da parcela anteriormente recebida, na forma da legislação aplicável, inclusive mediante procedimentos 
de fiscalização local, realizados periodicamente pela entidade ou órgão descentralizador dos recursos ou pelo órgão competente do sistema de controle interno da Administração Pública;

II - quando verificado desvio de finalidade na aplicação dos recursos, atrasos não justificados no cumprimento das etapas ou fases programadas, práticas atentatórias aos princípios fundamentais de Administração Pública nas contrataçóes e demais atos praticados na execuçáo do convênio, ou o inadimplemento do executor com relação a outras cláusulas conveniais básicas;

III - quando o executor deixar de adotar as medidas saneadoras apontadas pelo partícipe repassador dos recursos ou por integrantes do respectivo sistema de controle interno. (Grifo nosso)

A Portaria Interministerial n. 507/2011 também cuidou da matéria, especialmente em seu artigo 55:

Art. 55. Para recebimento de cada parcela dos recursos, o convenente deverá:

I - comprovar o cumprimento da contrapartida pactuada que, se financeira, deverá ser depositada na conta bancária específica do instrumento em conformidade com os prazos estabelecidos no cronograma de desembolso, ou depositada na Conta Única do Tesouro Nacional, na hipótese do convênio ou contrato de repasse ser executado por meio do Sistema Integrado de Administração Financeira - SIAFI;

II - atender às exigências para contratação e pagamento previstas nos arts. 56 a 64 desta Portaria; e

III - estar em situação regular com a execução do Plano de Trabalho. (Grifo nosso)

Não obstante, diversos dispositivos esparsos ao longo de seu texto versam sobre aspectos impeditivos da liberação de recursos, em decorrência tanto do artigo 116 da Lei Federal n. 8.666/93, quanto do artigo 55 da Portaria n. 507/2011, relacionados, especialmente: a) à boa e regular aplicação da parcela anteriormente recebida; b) à não ocorrência de desvio de finalidade, de atrasos não justificados, de práticas atentatórias aos princípios fundamentais de Administração Pública ou de descumprimento de outras cláusulas conveniais básicas; c) à não adoção de medidas saneadoras diante da constatação de eventuais irregularidades na execução do convênio; d) ao cumprimento da contrapartida; e) ao atendimento às exigências de contratação e pagamento; e f) à regular execução do plano de trabalho. 


\subsection{DA ADOÇÃO OBRIGATÓRIA DA MODALIDADE DE PREGÃO ELETRÔNICO NAS CONTRATAÇÕES}

Além dos requisitos extraídos da Constituição Federal, da Lei de Responsabilidade Fiscal, do Decreto Federal n. 6.170/2007 e da Portaria Interministerial n. 507/2011, outros requisitos podem ser identificados nas respectivas leis de diretrizes orçamentárias. Na verdade, referidas leis acabaram por se transformar em um importante instrumento de regulação das transferências voluntárias, haja vista a carência de uma legislação permanente e sistematizada acerca da matéria.

A imposição de exigências para a realização de transferências por meio da Lei de Diretrizes Orçamentárias está prevista pela própria Lei de Responsabilidade Fiscal, em seu artigo $4^{\circ}$ :

Art. $4^{\circ}$ A lei de diretrizes orçamentárias atenderá o disposto no $₫ 2^{\circ}$ do art. 165 da Constituição e:

I - disporá também sobre:

a) equilíbrio entre receitas e despesas;

b) critérios e forma de limitação de empenho, a ser efetivada nas hipóteses previstas na alínea $b$ do inciso II deste artigo, no art. $9^{\circ}$ e no inciso II do $\$ 1^{\circ}$ do art. 31 ;

c) (VETADO);

d) (VETADO);

e) normas relativas ao controle de custos e à avaliação dos resultados dos programas financiados com recursos dos orçamentos;

f) demais condiçôes e exigências para transferências de recursos a entidades públicas e privadas; (...) (Grifo nosso)

Em caráter exemplificativo, apontamos para a exigência, incluída pela primeira vez na Lei de Diretrizes Orçamentárias federal para o exercício de 2007 (Lei Federal n. 11.439, de 29 de dezembro de 2006), atinente à obrigatoriedade de o ente federado adotar a modalidade de pregão eletrônico em suas licitações, nas hipóteses legalmente admitidas. Nesse sentido, estabelece o artigo $45, \$ 5^{\circ}$, do mencionado diploma legal:

$\$ 5^{\circ}$ Sem prejuízo do disposto na Lei Complementar n.o 101, de 2001, constitui exigência para o recebimento de transferências voluntárias a adoção, por parte do convenente, dos procedimentos definidos pela União relativos à licitação, contratação, execução e controle, inclusive quanto à adoção da modalidade pregão eletrônico sempre que a legislação o permitir, salvo se justificadamente inviável a adoção dessa modalidade.

A Lei de Diretrizes Orçamentárias da União para o exercício de 2016 (Lei Federal n. 13.242, de 30 de dezembro de 2015, ainda contempla a previsão, conforme disposto em seu artigo $77, \S 3^{\circ}$ : 
$\$ 3^{\circ}$ Sem prejuízo dos requisitos contidos na Lei de Responsabilidade Fiscal, constitui exigência para o recebimento das transferências voluntárias a observância das normas publicadas pela União relativas à aquisição de bens e à contratação de serviços e obras, inclusive na modalidade pregão, nos termos da Lei n. 10.520, de 17 de julho de 2002, devendo ser utilizada preferencialmente a sua forma eletrônica.

Observa-se a amplitude da determinação, que não se limita a estabelecer a obrigatoriedade de pregão eletrônico nas contratações que envolvam a transferência voluntária específica, mas impõe um modelo de contratação geral, o que, em princípio, poderia causar estranheza, em razão da caracterização de uma espécie de invasão na esfera de autonomia dos entes federados pela União. Com efeito, ao impor o modelo de contratação a ser observado pelos convenentes por meio de suas leis de diretrizes orçamentárias, a União avança de forma ostensiva sobre os limites da autonomia administrativa dos demais entes federados, autonomia esta sujeita à limitação apenas pelo texto constitucional originário. Este obriga todos os entes federados a realizarem o processo licitatório de acordo com o procedimento estabelecido em lei nacional com fundamento constitucional, não sendo admissível a imposição de condicionantes que resvalem na esfera de autonomia federativa por instrumento normativo diverso da Constituição Federal e das normas gerais que nela se fundamentam. Ainda que tenha sido atribuído à Lei de Diretrizes Orçamentárias a possibilidade de impor exigências à realização de transferências voluntárias, a aptidão deve ser interpretada à luz dos princípios norteadores do sistema constitucional.

A Portaria n. 507/2011 também prevê a obrigatoriedade de adoção do pregão eletrônico nas aquisições decorrentes da realização do ajuste. Nesse sentido, estabelece o artigo 62:

Art. 62. Os órgãos e entidades públicas que receberem recursos da União por meio dos instrumentos regulamentados por esta Portaria estão obrigados a observar as disposições contidas na Lei Federal de Licitaçôes e Contratos Administrativos e demais normas federais pertinentes ao assunto, quando da contratação de terceiros.

$\$ 1^{\circ}$ Para aquisição de bens e serviços comuns, será obrigatório o uso da modalidade pregão, nos termos da Lei n. 10.520, de 17 de julho de 2002, e do regulamento previsto no Decreto n. 5.450, de 31 de maio de 2005, sendo utilizada preferencialmente a sua forma eletrônica.

$\$ 2^{\circ}$ A inviabilidade da utilização do pregão na forma eletrônica deverá ser devidamente justificada pela autoridade competente do convenente.

$\$ 3^{\circ}$ As atas e as informações sobre os participantes e respectivas propostas das licitações, bem como as informações referentes às dispensas e inexigibilidades, deverão ser registradas no SICONV. 
Ainda, caso se vislumbre a necessidade de parcerias com entidades de natureza privada, os entes públicos deverão realizar processo seletivo para a escolha da entidade:

Art. 63. Nos convênios celebrados pela União com Estados, Distrito Federal e Municípios deverá ser previsto compromisso do convenente de realizar processo seletivo para fins de escolha de entidade privada sem fins lucrativos, nos moldes dos arts. $8^{\circ} \mathrm{e}$ $9^{\circ}$ desta Portaria, nos casos em que a execução do objeto, conforme prevista no plano de trabalho, envolver parceria.

A previsão, neste caso, não se mostra antentatória à autonomia dos entes da federação, na medida em que se encontra diretamente atrelada ao ajuste celebrado, impondo condicionamentos para a execução do objeto específico do convênio.

\subsection{DA PREVISÃO DE CONTRAPARTIDA}

Tal como salientado acima, consiste a contrapartida em uma parcela de recursos a serem despendidos pelo ente federado como contribuição para a consecução do objeto de convênio custeado, em sua maior parte, pelos recursos advindos da transferência voluntária em questão.

O artigo 116 da Lei de Licitações (Lei Federal n. 8.666/93), notadamente seu $\$ 1^{\circ}$, inciso VII, prevê expressamente a figura da contrapartida nas obras e serviços de engenharia, mas dispõe de uma redação dúbia a respeito de sua real necessidade, posto que, ao mesmo tempo em que determina a necessidade de previsão de "recursos próprios para complementar a execução do objeto", ressalva expressamente as hipóteses de convênios em que o "custo total do empreendimento recai[a] sobre a entidade ou órgão descentralizador". ${ }^{5}$

45 Dispõem o caput e o $\$ 1^{\circ}$ do artigo 116: Art. 116. Aplicam-se as disposições desta Lei, no que couber, aos convênios, acordos, ajustes e outros instrumentos congêneres celebrados por órgãos e entidades da Administração.

$\$ 1^{\circ}$ A celebração de convênio, acordo ou ajuste pelos órgãos ou entidades da Administração Pública depende de prévia aprovação de competente plano de trabalho proposto pela organização interessada, o qual deverá conter, no mínimo, as seguintes informações:

I - identificação do objeto a ser executado;

II - metas a serem atingidas;

III - etapas ou fases de execução;

IV - plano de aplicação dos recursos financeiros;

$\mathrm{V}$ - cronograma de desembolso;

VI - previsão de início e fim da execução do objeto, bem assim da conclusão das etapas ou fases programadas;

VII - se o ajuste compreender obra ou serviço de engenharia, comprovação de que os recursos próprios para complementar a execução do objeto estão devidamente assegurados, salvo se o custo total do empreendimento recair sobre a entidade ou órgáo descentralizador. (...) (Grifo nosso) 
A previsão orçamentária de contrapartida também constitui exigência decorrente da Lei de Responsabilidade Fiscal, dentre as comprovaçôes a serem efetuadas pelo beneficiário elencadas no artigo $25, \S 1^{\circ}$, inciso IV, $d$. Ainda, consoante previsto no artigo 24 da Portaria Interministerial n. 507/2011, "a contrapartida, quando houver, será calculada sobre o valor total do objeto e poderá ser atendida por meio de recursos financeiros e de bens ou serviços, se economicamente mensuráveis". No caso específico dos entes públicos, poderá ser aceita contrapartida não financeira, salvo disposição legal em contrário (art. 24, $\$ 6^{\circ}$ ). Quando assumir caráter financeiro, a contrapartida "deverá ser comprovada por meio de previsão orçamentária" (art. 24, $\$ 5^{\circ}$ ) e será depositada na conta específica do convênio (art. 24, $\$ 1^{\circ}$ ).

A Cartilha explicativa do SICONV dá um panorama geral das contrapartidas que merece reprodução:

CONTRAPARTIDA. A contrapartida consiste em valor economicamente mensurável que será arcado pelo convenente como parte de suas obrigaçóes no convênio. As regras de contrapartida são definidas pelos órgãos concedentes no momento da divulgação do programa no Siconv, onde os órgãos devem observar os limites estabelecidos pela Lei de Diretrizes Orçamentárias - LDO vigente, conforme o exemplo abaixo: a) entre $2 \%$ (dois por cento) e $4 \%$ (quatro por cento) para Municípios com até cinquenta mil habitantes; b) $4 \%$ (quatro por cento) e $8 \%$ (oito por cento) para Municípios acima de cinquenta mil habitantes localizados nas áreas prioritárias definidas no âmbito da Política Nacional de Desenvolvimento Regional (PNDR), nas áreas da Superintendência do Desenvolvimento do Nordeste (Sudene), da Superintendência do Desenvolvimento da Amazônia (Sudam) e da Superintendência do Desenvolvimento do Centro-Oeste (Sudeco); c) 8\% (oito por cento) e 20\% (vinte por cento) para os demais. Fonte: Lei n. 12.708, de 17 de agosto de 2012.46

Consoante já salientado, as leis de diretrizes orçamentárias editadas anualmente constituem importante instrumento normatizador das transferências voluntárias, disciplinando diversos aspectos que as norteiam. Com a questão das contrapartidas não é diferente, e os maiores detalhamentos das contrapartidas são estatuídos justamente por elas.

Nessa medida, os percentuais de contrapartidas exigíveis nas transferências voluntárias realizadas pela União são objeto de definição pelas leis de diretrizes orçamentárias, tendo-se observado uma diminuição dos referidos percentuais nos dois últimos exercícios, em relação aos percentuais vigentes em 2013 - reduzidos em 2014 e mantidos assim em 2015. Estabelece o artigo 77 da Lei Federal n. 13.242, de 30 de dezembro de 2015, que dispõe sobre as diretrizes para a elaboração e execução da Lei Orçamentária de 2016:

46 BRASIL. Ministério do Planejamento, Orçamento e Gestão, cit., p. 5. Grifo nosso. 


\section{Das Transferências Voluntárias}

Art. 77. A realização de transferências voluntárias, conforme definidas no caput do art. 25 da Lei de Responsabilidade Fiscal, dependerá da comprovação, por parte do convenente, de que existe previsão de contrapartida na lei orçamentária do Estado, Distrito Federal ou Município.

$\$ 1^{\circ}$ A contrapartida, exclusivamente financeira, será estabelecida em termos percentuais do valor previsto no instrumento de transferência voluntária, considerando-se a capacidade financeira da respectiva unidade beneficiada e seu Índice de Desenvolvimento Humano - IDH, tendo como limite mínimo e máximo:

I - no caso dos Municípios:

a) $0,1 \%$ (um décimo por cento) e $4 \%$ (quatro por cento) para Municípios com até cinquenta mil habitantes;

b) $0,2 \%$ (dois décimos por cento) e $8 \%$ (oito por cento) para Municípios acima de cinquenta mil habitantes localizados nas áreas prioritárias definidas no âmbito da Política Nacional de Desenvolvimento Regional - PNDR, nas áreas da Superintendência do Desenvolvimento do Nordeste - SUDENE, da Superintendência do Desenvolvimento da Amazônia - SUDAM e da Superintendência do Desenvolvimento do Centro-Oeste - SUDECO;

c) $1 \%$ (um por cento) e $20 \%$ (vinte por cento) para os demais; e

d) $0,1 \%$ (um décimo por cento) a 5\% (cinco por cento) no caso de Municípios com até 200 mil habitantes, situados em áreas vulneráveis a eventos extremos, como: secas, deslizamentos, inundações, incluídas na lista classificatória de vulnerabilidade e recorrência de mortes por desastres naturais fornecida pelo MCTI;

II - no caso dos Estados e do Distrito Federal:

a) $0,1 \%$ (um décimo por cento) e $10 \%$ (dez por cento) se localizados nas áreas prioritárias definidas no âmbito da PNDR, nas áreas da SUDENE, SUDAM e SUDECO; e

b) $2 \%$ (dois por cento) e $20 \%$ (vinte por cento) para os demais;

III - no caso de consórcios públicos constituídos por Estados, Distrito Federal e Municípios, $0,1 \%$ (um décimo por cento) e $4 \%$ (quatro por cento).

$\$ 2^{\circ}$ Os limites mínimos e máximos de contrapartida fixados no $\$$ 1o poderão ser reduzidos ou ampliados, mediante critérios previamente definidos ou justificativa do titular do órgão concedente, quando:

I - necessário para viabilizar a execução das ações a serem desenvolvidas;

II - necessário para transferência de recursos, conforme disposto na Lei n. 10.835, de 8 de janeiro de 2004; ou

III - decorrer de condições estabelecidas em contratos de financiamento ou acordos internacionais. (...) (Grifo nosso) 
Observe-se que, contrariamente ao disposto no artigo $7^{\circ}$ do Decreto Federal n. 6.170/2007, que admite a possibilidade de a contrapartida ser atendida por meio de recursos financeiros, de bens e serviços, desde que economicamente mensuráveis, a Lei de Diretrizes Orçamentárias de 2015 determina que a contrapartida seja "exclusivamente financeira", utilizando como referência para a fixação do percentual devido o Índice de Desenvolvimento Humano do ente federado.

Referido índice é elaborado pelo Programa das Naçôes Unidas para o Desenvolvimento (PNUD), entidade da Organização das Nações Unidas (ONU) voltada ao desenvolvimento e à eliminação da pobreza mundiais. Foi criado por Mahbub ul Haq com a colaboração do economista indiano Amartya Sen, ganhador do Prêmio Nobel de Economia de 1998, como medida alternativa ao PIB para aferição do desenvolvimento dos países, tendo como foco a pessoa humana e não a economia das nações avaliadas. ${ }^{47}$

O índice é calculado anualmente e leva em conta basicamente três critérios: saúde, educação e renda. A saúde é aferida pela expectativa de vida do país; a educação é avaliada pela medida de anos de educação dos adultos e pela expectativa de escolaridade das crianças ao ingressar na vida escolar; e a renda é medida pela Renda Nacional Bruta (RNB) per capita, a qual considera o poder de paridade de compra tendo como base o ano de 2005, utilizando o dólar como referência.

Ao lado do IDH Global, foi desenvolvido o Índice de Desenvolvimento $\mathrm{Hu}$ mano Municipal (IDHM), que leva em conta as mesmas variáveis adotadas na formulação do IDH Global - saúde, educação e renda -, mas tem como foco o contexto brasileiro, por meio da formulação de um ranking próprio dos entes federados em âmbito nacional.

Assim, o que a LDO veicula são os limites percentuais mínimo e máximo das contrapartidas, a serem definidos dentro dos referidos limites percentuais, mediante critérios atinentes à capacidade financeira da unidade beneficiada e ao seu respectivo Índice de Desenvolvimento Humano (IDH). Dessa forma, no tocante aos Municípios, os limites percentuais das contrapartidas estão fixados na seguinte conformidade:

a) entre $0,1 \%$ e $4 \%$ do valor do ajuste para os Municípios com até cinquenta mil habitantes;

b) entre $0,2 \%$ e $8 \%$ para os Municípios acima de cinquenta mil habitantes localizados nas seguintes localidades:

47 PROGRAMA DAS NAÇÕES UNIDAS PARA O DESENVOLVIMENTO (PNUD). O que é o IDH. Portal do PNUD. Disponível em: <http://www.pnud.org.br/IDH/IDH.aspx? indiceAccordion=0\&li=li_IDH>. Acesso em: 25 ago. 2014. 
i) áreas prioritárias definidas no âmbito da Política Nacional de Desenvolvimento Regional - PNDR;

A PNDR foi instituída por meio do Decreto Federal n. 6.047, de 22 de fevereiro de 2007, tendo por objetivo "a redução das desigualdades de nível de vida entre as regiōes brasileiras e a promoção da equidade no acesso a oportunidades de desenvolvimento, e deve orientar os programas e ações federais no Território Nacional" (art. $1^{\circ}$ ). Constituem áreas de tratamento prioritário da PNDR, o Semi-Árido, a Faixa de Fronteira e as Regiōes Integradas de Desenvolvimento (RIDE), definidas no Anexo I do mencionado Decreto $\left(\operatorname{art.} 3^{\circ}, \$ 4^{\circ}\right) .4^{48}$

ii) nas áreas da Superintendência do Desenvolvimento do Nordeste - SUDENE;

48 Vejam-se o artigo $3^{\circ}$, seu $₫ 4^{\circ}$ e o anexo I do Decreto: Art. $3^{\circ}$ A PNDR comportará a definição de estratégias de desenvolvimento regional nas escalas seguintes:

(...)

$\$ 40$ São áreas de tratamento prioritário da PNDR o Semi-Árido, a Faixa de Fronteira e as Regiōes Integradas de Desenvolvimento - RIDE's, definidas conforme Anexo I deste Decreto, bem como outras áreas consideradas relevantes, a partir de impacto territorial previsível decorrente de investimentos estruturantes, a serem promovidos pelo Governo Federal.

(...)

ANEXO I

MESORREGIÕES DIFERENCIADAS

1. MESORREGIÃO DO ALTO SOLIMÕES

2. MESORREGIÃO DO VALE DO RIO DO ACRE

3. MESORREGIÃO DO BICO DO PAPAGAIO

4. MESORREGIÃO DA CHAPADA DAS MANGABEIRAS

5. MESORREGIÃO DO XINGÓ

6. MESORREGIÃO DA BACIA DO ITABAPOANA

7. MESORREGIÃO DOS VALES DO RIBEIRA E GUARAQUEÇABA

8. MESORREGIÃO DA GRANDE FRONTEIRA DO MERCOSUL

9. MESORREGIÃO DA METADE SUL DO RIO GRANDE DO SUL

10. MESORREGIÃO DO SERIDÓ

11. MESORREGIÃO DAS ÁGUAS EMENDADAS

12. MESORREGIÃO DA CHAPADA DO ARARIPE

13. MESORREGIÃO DOS VALES DO JEQUITINHONHA E DO MUCURI

14. MESORREGIÃO DO XINGU

Sub-regiōes selecionadas pela Câmara de Políticas de Integração Nacional e Desenvolvimento Regional

1. São Raimundo Nonato - PI

2. Médio e Baixo Jaguaribe - CE

3. Vale do Açu - RN

4. Souza - Piancó - PB

5. Sertão do Moxotó - PE

6. Santana do Ipanema - AL

7. Sergipana Sertão do São Francisco - SE 
Além dos nove Estados da região Nordeste, a SUDENE abarca ainda alguns Municípios dos Estados de Minas Gerais e do Espírito Santo, consoante definido

8. Brumado/Bom Jesus da Lapa/Guanambi - BA

9. Serra Geral - MG

10. Sub-Região da Área de Abrangência do Plano da BR-163 Sustentável.

11. Sub-região da Área de Abrangência do Plano de Desenvolvimento Regional Sustentável do Xingu - PDRS do Xingu

REGIỐES INTEGRADAS DE DESENVOLVIMENTO - RIDE's

1. RIDE DO PÓLO DE JUAZEIRO E PETROLINA

Criada pela Lei Complementar n. 113, de 19/09/2001

UF: PERNAMBUCO

Municípios:

PETROLINA;

LAGOA GRANDE;

SANTA MARIA DA BOA VISTA;

OROCÓ;

UF: BAHIA

Municípios:

JUAZEIRO;

CASA NOVA;

CURAÇÁ;

SOBRADINHO;

2. RIDE DA GRANDE TERESINA - TIMON

Criada pela Lei Complementar n. 112, de 19/09/2001

UF: PIAUI

Municípios:

ALTOS;

BENEDITINOS;

COIVARAS;

CURRALINHO;

JOSÉ DE FREITAS;

DERMEVAL LOBÃO;

LAGOA ALEGRE;

LAGOA DO PIAUÍ;

MIGUEL LEÃO;

MONSENHOR GIL;

TERESINA;

UNIÂO;

UF: MARANHÃO

Município:

TIMON

3. RIDE DO ENTORNO DO DF

Criada pela Lei Complementar n. 94, de 19/02/1998

UF: GOIÁS

Municípios:

ABADIÂNIA; 
no caput do artigo $2^{\circ}$ da Lei Complementar n. 125 , de 3 de janeiro de $2007,{ }^{49}$ congregando, no momento, um total de 1989 Municípios, conforme dados fornecidos pela própria SUDENE. ${ }^{50}$

iii) nas áreas da Superintendência do Desenvolvimento da Amazônia - SUDAM;

A área de abrangência da SUDAM compreende todos os seis Estados da Região Norte, além dos Estados do Mato Grosso e do Maranhão, este na porção a

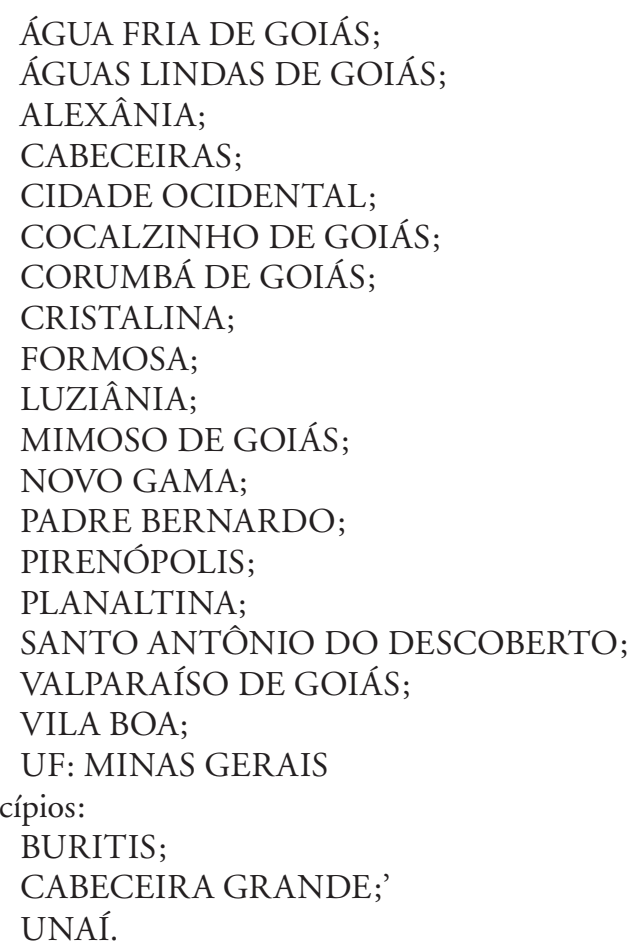

Dispõe o artigo 2º da LC n. 125/2007: Art. 2o A área de atuação da Sudene abrange os Estados do Maranhão, Piauí, Ceará, Rio Grande do Norte, Paraíba, Pernambuco, Alagoas, Sergipe, Bahia e as regióes e os Municípios do Estado de Minas Gerais de que tratam as Leis ns. 1.348, de 10 de fevereiro de 1951, 6.218, de 7 de julho de 1975, e 9.690, de 15 de julho de 1998, bem como os Municípios de Águas Formosas, Angelândia, Aricanduva, Arinos, Ataléia, Bertópolis, Campanário, Carlos Chagas, Catuji, Crisólita, Formoso, Franciscópolis, Frei Gaspar, Fronteira dos Vales, Itaipé, Itambacuri, Jenipapo de Minas, José Gonçalves de Minas, Ladainha, Leme do Prado, Maxacalis, Monte Formoso, Nanuque, Novo Oriente de Minas, Ouro Verde de Minas, Pavão, Pescador, Ponto dos Volantes, Poté, Riachinho, Santa Fé de Minas, Santa Helena de Minas, São Romão, Serra dos Aimorés, Setubinha, Teófilo Otoni, Umburatiba e Veredinha, todos em Minas Gerais, e ainda os Municípios do Estado do Espírito Santo relacionados na Lei n. 9.690, de 15 de julho de 1998, bem como o Município de Governador Lindemberg. BRASIL. Superintendência do Desenvolvimento do Nordeste - SUDENE. Municípios da área de atuação da SUDENE. Portal da SUDENE. Disponível em: <http://www.sudene.gov. br/conteudo/download/area-SUDENE.pdf>. Acesso em: 25 ago. 2014. 
oeste do Meridiano $44^{\circ}$, conforme definido pelo caput do artigo $2^{\circ}$ da Lei Complementar n. 124, de 3 de janeiro de 2007.51

iv) nas áreas da Superintendência do Desenvolvimento do Centro-Oeste - SUDECO;

Criada pela Lei Complementar n. 129, de 8 de janeiro de 2009, a SUDECO tem por finalidade promover o desenvolvimento regional, de forma includente e sustentável, e a integração competitiva da base produtiva regional na economia nacional e internacional, abrangendo os Estados de Mato Grosso, Mato Grosso do Sul e Goiás, além do Distrito Federal (artigo $\left.2^{\circ}\right) .^{52}$

c) entre $1 \%$ e $20 \%$ para os demais Municípios, abarcando os Municípios das regiōes Sul e Sudeste, com exceção feita a alguns Municípios dos Estados de Minas Gerais e Espírito Santo, abarcados pela área de abrangência da SUDENE;

d) $0,1 \%$ (um décimo por cento) a $5 \%$ (cinco por cento) no caso de Municípios com até 200 mil habitantes, situados em áreas vulneráveis a eventos extremos, como: secas, deslizamentos, inundaçóes, incluídas na lista classificatória de vulnerabilidade e recorrência de mortes por desastres naturais fornecida pelo MCTI.

Verifica-se, assim, o tratamento diferenciado atribuído às regiões, beneficiadas com percentuais inferiores de contrapartidas para o recebimento de transferências voluntárias do governo federal.

No tocante aos Estados, consoante visto, o tratamento diferenciado se mantém, adotando-se os mesmos critérios de fixação das contrapartidas nos casos dos Municípios:

a) entre $0,1 \%$ e $10 \%$ (dez por cento) se localizados nas áreas prioritárias definidas no âmbito da PNDR, e nas áreas da SUDENE, SUDAM e SUDECO, abrangendo, assim, todos os Estados das Regiôes Norte, Nordeste e Centro-Oeste, além do Distrito Federal; e

b) entre $2 \%$ e $20 \%$ para os demais Estados, entendidos estes como Estados das regiōes Sul e Sudeste.

Por fim, nos casos de consórcios públicos, o percentual de contrapartida varia entre $0,1 \%$ e $4 \%$.

Uma importante ressalva é efetuada pela LDO federal, no sentido de eximir os entes federados da contrapartida quando o ajuste envolver ações incluídas no

51 Dispõe o artigo 2o: Art. 2o A área de atuação da Sudam abrange os Estados do Acre, Amapá, Amazonas, Mato Grosso, Rondônia, Roraima, Tocantins, Pará e do Maranhão na sua porção a oeste do Meridiano $44^{\circ}$.

52 Dispóe o artigo 2o: Art. 2o A área de atuação da Sudeco abrange os Estados de Mato Grosso, Mato Grosso do Sul e Goiás e o Distrito Federal. 
âmbito do Sistema Único de Saúde (SUS), nos termos do $\$ 4^{\circ}$ do mencionado artigo 77 da Lei Federal n. 13.242/2015, segundo o qual "para a transferência de recursos no âmbito do SUS, inclusive a efetivada mediante convênios ou similares, não será exigida contrapartida dos Estados, do Distrito Federal e dos Municípios”.

Não obstante a extensa regulamentação das transferências voluntárias pelas leis de diretrizes orçamentárias da União, a Lei de Diretrizes Orçamentárias do Estado de São Paulo, por sua vez, não contém previsão acerca das contrapartidas, dispondo, em verdade, de apenas um único dispositivo que trata das transferências voluntárias, conforme teor do artigo 31 da Lei Estadual n. 15.870, de 27 de julho de 2015:

Art. 31. As transferências voluntárias de recursos do Estado para os Municípios, a título de cooperação, auxílio ou assistência financeira, dependerão da comprovação, por parte da unidade beneficiada, no ato da assinatura do instrumento original, de que se encontra em conformidade com o disposto no artigo 25 da Lei Complementar Federal n. 101, de 4 de maio de 2000, na Lei n. 12.799, de 11 de janeiro de 2008, e no Decreto n. 40.722, de 20 de março de 1996, com alterações posteriores. ${ }^{53-54}$

\subsection{DA PROPRIEDADE DOS BENS REMANESCENTES}

A propriedade dos bens remanescentes sobressai como questão relevante a ser incluída nos termos do ajuste celebrado, em razão da importância em se estabelecer a quem cabe a propriedade do bem construído, adquirido, produzido ou transformado por meio do convênio.

53 A Lei Estadual n. 12.799/2008 dispõe sobre o Cadastro Informativo dos Créditos não Quitados de órgãos e entidades estaduais - CADIN ESTADUAL, e contém previsão atinente às transferências voluntárias em seu artigo $6, \$ 2^{\circ}$ : Art. $6^{\circ}$ É obrigatória consulta prévia ao CADIN ESTADUAL, pelos órgãos e entidades da Administração direta e indireta, para:

I - celebração de convênios, acordos, ajustes ou contratos que envolvam o desembolso, a qualquer título, de recursos financeiros;

II - repasses de valores de convênios ou pagamentos referentes a contratos;

III - concessão de auxílios e subvenções;

IV - concessão de incentivos fiscais e financeiros.

$\$ 1^{\circ}$ - A existência de registro no CADIN ESTADUAL constituirá impedimento à realização dos atos a que se referem os incisos I a IV deste artigo.

$\$ 2^{\circ}-O$ disposto neste artigo não se aplica à concessão de auxílios a Municípios atingidos por calamidade pública reconhecida pelo Governo do Estado e às transferências voluntárias de que trata o $\$ 3^{\circ}$ do artigo 25 da Lei Complementar federal n. 101, de 4 de maio de 2000. (Grifo nosso)

54 Mencionado decreto dispõe sobre a exigência de autorização do Governador do Estado previamente à celebração de convênios no âmbito da Administração Centralizada e sobre a instrução dos processos respectivos. 
Guilherme Henrique de la Rocque Almeida alerta para a necessidade de disposição expressa acerca da propriedade dos bens. Nesse sentido, prevê, enquanto cláusula obrigatória nos termos dos convênios, a "disposição expressa sobre o direito de propriedade relativo aos bens remanescentes que tenham sido adquiridos, produzidos, transformados ou construídos em função da avença”, e complementa afirmando que "em geral, os bens remanescentes pertencem ao convenente". 55

A necessidade é expressamente prevista pelo artigo 41 da Portaria n. 507/2011, ao dispor que "será obrigatória a estipulação do destino a ser dado aos bens remanescentes do convênio", sendo considerados bens remanescentes "os equipamentos e materiais permanentes adquiridos com recursos do convênio necessários à consecução do objeto, mas que não se incorporam a este” (art. 41, $₫ 1^{\circ}$ ).

\subsection{A IMPORTÂNCIA DO SISTEMA DE GESTÃO DE CONVÊNIOS E CONTRATOS DE REPASSE (SICONV)}

Um importante instrumento de operacionalização e controle das transferências voluntárias realizadas por meio de convênios e contratos de repasse reside no Sistema de Gestão de Convênios e Contratos de Repasse (SICONV). Trata-se de um sistema no qual todos os programas do Governo Federal são disponibilizados para execução de projetos e atividades de interesse recíproco que envolvem a transferência de recursos financeiros oriundos do Orçamento Fiscal e da Seguridade Social da União.

Os programas são disponibilizados pelos respectivos ministérios por órgão, ano e nome do programa, ou por emenda parlamentar, quando for o caso. Os programas podem ser destinados aos Estados e ao Distrito Federal, aos Municípios e às entidades privadas sem fins lucrativos. As transferências às últimas não serão abordadas por não constituírem objeto de nosso estudo, que está adstrito apenas às transferências voluntárias entre os entes da federação.

A divulgação dos programas é efetuada por meio do próprio sistema, concebido para atuar em todas as fases do processo de transferências voluntárias, desde a divulgação até a prestação de contas e eventual devolução de saldo remanescente. Dessa forma, os entes federados devem acompanhar a divulgação dos programas e apresentar suas propostas diretamente junto ao SICONV.

A obrigatoriedade de chamamento público das entidades privadas sem fins lucrativos vem expressa no artigo $4^{\circ}$ do Decreto Federal n. 6.170/2007, na redação que lhe foi conferida pelo Decreto Federal n. 7.568/2011:

55 ALMEIDA, Guilherme Henrique de La Rocque, cit., p. 166. 
Art. $4^{\circ}$ A celebração de convênio ou contrato de repasse com entidades privadas sem fins lucrativos será precedida de chamamento público a ser realizado pelo órgão ou entidade concedente, visando à seleção de projetos ou entidades que tornem mais eficaz o objeto do ajuste.

Nesse sentido, na medida em que o dispositivo foi expresso apenas em relação aos convênios celebrados com as entidades privadas sem fins lucrativos, questiona-se se o chamamento público estaria, assim, dispensado no tocante à celebração de convênios com os demais entes federados. A Portaria Interministerial n. 507/2011, por meio de seus artigos $7^{\circ}$ e $8^{\circ}$, parece elucidar a questão:

Art. $7^{0}$ Para a celebração dos instrumentos regulados por esta Portaria com entes públicos, o órgão ou entidade da Administração Pública Federal poderá, com vista a selecionar projetos e órgãos ou entidades públicas que tornem mais eficaz a execução do objeto, realizar chamamento público no SICONV, que deverá conter, no mínimo:

I - a descrição dos programas a serem executados de forma descentralizada; e

II - os critérios objetivos para a seleção do convenente ou contratado, com base nas diretrizes e nos objetivos dos respectivos programas.

Parágrafo único. Deverá ser dada publicidade ao chamamento público, pelo prazo mínimo de 15 (quinze) dias, especialmente por intermédio da divulgação na primeira página do sítio oficial do órgão ou entidade concedente, bem como no Portal dos Convênios.

Art. $8^{\circ}$ A formação de parceria para execução descentralizada de atividades, por meio de convênio ou termo de parceria, com entidades privadas sem fins lucrativos deverá ser precedida de chamamento público ou concurso de projetos a ser realizado pelo órgão ou entidade concedente, visando à seleção de projetos ou entidades que tornem eficaz o objeto do ajuste. (...) (Grifo nosso)

Dessa forma, fica caracterizada a obrigatoriedade de realização de chamamento público das entidades privadas sem fins lucrativos, ao passo em que o mesmo procedimento é apenas uma faculdade quando a celebração envolver outros entes públicos, entre os quais os entes federados. Contudo, uma vez efetuado o chamamento público para a celebração de ajustes com entes públicos, aí incluídos aqueles que envolvem o repasse de recursos financeiros na forma prevista pelo artigo 25 da Lei de Responsabilidade Fiscal, deverão ser divulgados os critérios objetivos para a seleção do convenente ou contratado, com base nas diretrizes e nos objetivos dos respectivos programas.

Além de operacionalizar o sistema de convênios, o SICONV também é um importante instrumento de controle e transparência das transferências voluntárias realizadas, tendo em vista que possibilita o acesso a dados relevantes para o controle por parte de qualquer interessado, como: a) a relação dos programas com recursos disponibilizados; b) os dados do ente federado ou da entidade convenente; c) o objeto pactuado; d) o plano de trabalho detalhado; e) os custos de cada uma 
de suas fases; f) os recursos envolvidos; g) os dados atualizados do cronograma de execução física; h) os procedimentos licitatórios realizados; i) os dados de todos os beneficiários; j) a execução financeira em detalhes, com todos os pagamentos realizados; k) as informações sobre a execução física do objeto; l) os dados relacionados à prestação de contas, entre outros aspectos essenciais.

A operacionalização via SICONV dos convênios e contratos de repasse passou a ser realizada a partir de $1^{\circ}$ de setembro de 2008, tornando-se obrigatória, no entanto, a partir de 16 de janeiro de 2012, por força do disposto no artigo 18-B do Decreto Federal n. 6.170/2007, inserido pelo Decreto Federal n. 7.641/2011:

Art. 18-B. A partir de 16 de janeiro de 2012, todos os órgãos e entidades que realizem transferências de recursos oriundos dos Orçamentos Fiscal e da Seguridade Social da União por meio de convênios, contratos de repasse ou termos de parceria, ainda não interligadas ao SICONV, deverão utilizar esse sistema.

Parágrafo único. Os órgãos e entidades que possuam sistema próprio de gestão de convênios, contratos de repasse ou termos de parceria deverão promover a integração eletrônica dos dados relativos às suas transferências ao SICONV, passando a realizar diretamente nesse sistema os procedimentos de liberação de recursos, acompanhamento e fiscalização, execução e prestação de contas.

Paulatinamente, algumas funcionalidades foram sendo inseridas e tornando-se obrigatórias, revelando um aprimoramento do sistema ao longo do tempo. A título de exemplo, aponta-se para o seguinte cronograma de implantação, veiculado pelo Decreto Federal n. 7.641/2011:

Art. $3^{\circ}$ Ficam estabelecidos os prazos para implantação, pelo Ministério do Planejamento, Orçamento e Gestão, das seguintes funcionalidades no SICONV:

I - até 16 de janeiro de 2012: Acompanhamento e Fiscalização;

II - até 2 de maio de 2012: Chamamento Público, Módulo Específico para Termos de Parceria, Cotação Prévia de Preços para as Entidades Privadas sem Fins Lucrativos e Tomada de Contas Especial; e

III - até 30 de julho de 2012: Ordem Bancária de Transferências Voluntárias.

Consoante dispõe o artigo $3^{\circ}$ da Portaria Interministerial n. 507/2011:

(...) os atos e os procedimentos relativos à formalização, execução, acompanhamento, prestação de contas e informações acerca de tomada de contas especial dos convênios e termos de parceria serão realizados no Sistema de Gestão de Convênios e Contratos de Repasse - SICONV, aberto à consulta pública, por meio do Portal dos Convênios.

Seu $₫ 1^{\circ}$ estabelece ainda que "os atos que, por sua natureza, não possam ser realizados noSICONV, serão nele registrados". Observa-se, assim, a compulsoriedade da utilização do sistema para a realização de todos os atos preparatórios e executórios das transferências voluntárias efetuadas pela União. 
A instituição do SICONV veio a atender uma série de expectativas em relação ao controle de todas as fases de execução de convênios passo a passo, mostrando-se um instrumento de extrema relevância para o acompanhamento dos convênios celebrados pelos entes da administração pública que envolvem a transferência de recursos financeiros. Não se trata de uma mera norma a ser observada pelos entes federados e convenentes, mas sim um sistema que se pretende ser amplamente acessível a todos os interessados, funcionando como um espelho dos documentos, refletor de todas as etapas de realização do convênio, desde a apresentação da proposta até a aprovação das contas.

Nesse sentido, destaca-se o conceito do sistema extraído de cartilha elaborada pela Secretaria de Logística e Tecnologia da Informação do Ministério do Planejamento, Orçamento e Gestão (SLTI/MP):

(...) sistema aberto à consulta pública que tem por objetivo permitir a realização de atos e procedimentos relativos à formalização, execução, acompanhamento, prestação de contas e informações acerca de tomada de contas especial dos convênios, contratos de repasse e termos de parceria celebrados pela União. Para realizar esses procedimentos no SICONV o Município deve estar credenciado e cadastrado. É importante esclarecer que a operacionalização das transferências voluntárias da União é realizada no SICONV e o sítio é a 'porta' para o acesso ao sistema. ${ }^{56}$

Dessa forma, todas as transferências voluntárias efetuadas pela União passaram a ser operacionalizadas por meio do SICONV, contribuindo para a ampliação do acesso aos recursos federais, na medida em que os entes federados e as entidades da sociedade civil interessadas na obtenção de recursos podem se "candidatar" à celebração do ajuste com a União. Nessa hipótese, os órgãos da União responsáveis publicam, por meio do sistema, os programas governamentais com recursos disponibilizados. Os entes interessados devem apresentar seus planos de trabalhos, devidamente justificados, com vistas à aprovação pelos órgãos federais para a realização do ajuste.

Nessa medida, dispõe a citada cartilha:

Com a implantação do Siconv, a democratização na distribuição dos recursos públicos por meio das transferências voluntárias foi ampliada, visto que os órgãos responsáveis pela execução das políticas públicas que envolvem transferências de recursos devem publicar anualmente no Portal de Convênios a relação dos seus programas governamentais. Em contrapartida, os estados, o Distrito Federal, os Municípios e as entidades privadas sem fins lucrativos têm a possibilidade do envio eletrônico de propostas, fato que, inegavelmente, proporciona a todos os proponentes igualdade de condiçóes para pleitear os recursos federais destinados à execução de projetos e atividades de interesse comum, independente de filiação partidária. Por isso, o SICONV pode ser considerado um Sistema apartidário e democrático, na medida em que atende a todos os Municípios sem distinção. ${ }^{57}$

56 BRASIL. Ministério do Planejamento, Orçamento e Gestão, cit., p. 3.

57 BRASIL. Ministério do Planejamento, Orçamento e Gestão, cit., p. 3. Grifo nosso. 
Não obstante a extrema relevância ostentada pelo SICONV, especialmente nos aspectos relacionados à transparência e à maior acessibilidade aos recursos públicos, por conta da ampla divulgação e da possibilidade de os entes interessados se candidatarem aos programas disponibilizados na esfera federal, sobressai no contexto analisado a vulnerabilidade de certos Municípios diante do sistema, tendo em vista a necessidade de que tomem a iniciativa para pleitear recursos junto aos projetos desenvolvidos no âmbito da União.

Exige-se, assim, um aparato técnico com treinamento suficiente para interagir junto ao sistema, o que nem sempre é uma tarefa fácil para alguns Municípios brasileiros que detêm estrutura precária de assessoramento técnico e até mesmo tecnológico para a participação no processo. Com efeito, na medida em que "o acesso aos recursos se dá por meio de proposta ou projeto formulado pelo próprio interessado, diretamente ao Ministério/Secretaria ou à entidade que disponha de recursos aplicáveis ao objeto pretendido, ou quando se deseja implementar programas federais", 58 torna-se necessária a existência de uma estrutura capaz de viabilizar a participação do ente federado em todas as etapas operacionalizadas via SICONV, desde a captação dos recursos até a efetiva prestação de contas.

Além disso, embora se reconheça a maior amplitude de acesso ao sistema e a diminuição das influências político-partidárias, tal não significa o afastamento da influência na sistemática das transferências voluntárias. Com efeito, ainda que operacionalizadas por meio do SICONV, o sistema de aprovação e liberação das emendas parlamentares é diferenciado, exigindo uma fase prévia de liberação para a disponibilização do programa por meio do sistema informatizado. Conquanto hoje, com a introdução das emendas parlamentares de execução obrigatória, a discricionariedade na liberação de recursos para a execução das emendas tenha sido substancialmente alterada, conforme será analisado em tópico específico, ainda existe certa dose de flexibilidade na liberação dos programas e dos recursos a serem disponibilizados, observando-se, ainda, que nem todas as transferências voluntárias são decorrentes de emendas parlamentares.

Segundo dados do Ministério do Planejamento, "cerca de 95\% dos Municípios brasileiros utilizam o SICONV para enviar seus projetos, que passam por critérios rigorosos de aprovação. $\mathrm{O}$ cadastramento é feito no portal do sistema, onde estão disponíveis informações sobre normas e orientações para a celebração das parcerias com o governo federal". 59

58 CIRIBELI, João Paulo; MIQUELITO, Samuel; MASSARDI, Wellington de Oliveira, cit., p. 75.

59 BRASIL. Ministério do Planejamento, Orçamento e Gestão. Municípios recebem 76\% das transferências voluntárias da União até setembro. Portal do MPOG, publicado em 16 abr. 2015, última modificação em 16 abr. 2015. 


\subsubsection{Credenciamento e cadastramento no SICONV}

O primeiro requisito a ser observado para a realização de ajustes e para o recebimento de transferências voluntárias advindas da União concerne ao credenciamento e cadastramento dos entes no sistema.

O credenciamento no SICONV consiste basicamente no preenchimento de um formulário diretamente no Portal dos Convênios, viabilizando, assim, a apresentação de propostas de trabalho não restritas aos entes cadastrados. Nesse sentido, estabelece o Manual do Usuário do SICONV, elaborado pelo Ministério do Planejamento, Orçamento e Gestão:

O Credenciamento será realizado, uma única vez, diretamente no Portal dos Convênios - SICONV e conterá, no mínimo, as seguintes informações:

I - nome, endereço da sede, endereço eletrônico institucional e número de inscrição no Cadastro Nacional de Pessoas Jurídicas - CNPJ, bem como endereço residencial do responsável que assinará o instrumento, quando se tratar de instituiçôes públicas; e

II - razão social, endereço, endereço eletrônico, número de inscrição no Cadastro Nacional de Pessoas Jurídicas - CNPJ, transcrição do objeto social da entidade atualizado, relação nominal atualizada dos dirigentes da entidade, com endereço, número e órgão expedidor da carteira de identidade e CPF de cada um deles, quando se tratar das entidades privadas sem fins lucrativos.

Este credenciamento dará ao Proponente login e senha para acesso ao sistema que poderá também ser acessado usando Certificado Digital conforme informaçôes constantes no Manual - "Logar Siconv". ${ }^{60}$

Em continuidade, o Manual orienta quanto ao envio de propostas pelos entes credenciados:

De posse do login e senha ou Certificado Digital, o Proponente poderá enviar propostas para os Programas disponibilizados que aceitam propostas de Proponentes não cadastrados, ou seja, apenas credenciados, observando que, depois de enviada e sendo a proposta aprovada o Proponente deverá se cadastrar em uma Unidade Cadastradora. ${ }^{61}$

Já o cadastramento habilita "os órgãos e entidades da administração pública e entidades privadas sem fins lucrativos, que se interessem em firmar convênios em quaisquer áreas de atuação do governo federal, a apresentar proposta de trabalho ao

60 BRASIL. Ministério do Planejamento, Orçamento e Gestão; Secretaria de Logística e Tecnologia da Informação; Departamento de Gestão Estratégica da Informação. Portal dos Convênios - SICONV - Cadastro de Proponente - Manual do Usuário versão 11 - 26/12/2013. Brasília: SERPRO, 2013, p. 3.

${ }^{61}$ BRASIL. Ministério do Planejamento, Orçamento e Gestão; Secretaria de Logística e Tecnologia da Informação; Departamento de Gestão Estratégica da Informação, cit., p. 3. 
órgão ou entidade concedente". ${ }^{2}$ Nos termos do $\$ 2^{\circ}$ do artigo $3^{\circ}$ da Portaria Interministerial n. 507/2011, "para a celebração dos instrumentos regulados por esta Portaria, os órgãos, entidades e entes a que se refere o art. $1^{\circ}$ devem estar cadastrados no SICONV". O credenciamento é efetuado uma única vez, ao passo que o cadastramento tem validade de um ano, contado da aprovação do cadastro.

A consulta aos programas disponibilizados pelos órgãos e pelas entidades da administração pública federal para a execução de projetos e atividades é efetuada diretamente no portal do SICONV, com vistas à posterior celebração de convênios e contratos de repasse.

\subsubsection{Da prestação de contas}

O dever de prestar contas decorre do próprio texto constitucional, que estatui, em seu artigo 70, parágrafo único, a amplitude da obrigação:

Art. 70. A fiscalização contábil, financeira, orçamentária, operacional e patrimonial da União e das entidades da administração direta e indireta, quanto à legalidade, legitimidade, economicidade, aplicação das subvençôes e renúncia de receitas, será exercida pelo Congresso Nacional, mediante controle externo, e pelo sistema de controle interno de cada Poder.

Parágrafo único. Prestará contas qualquer pessoa física ou jurídica, pública ou privada, que utilize, arrecade, guarde, gerencie ou administre dinheiros, bens e valores públicos ou pelos quais a União responda, ou que, em nome desta, assuma obrigaçôes de natureza pecuniária.

No caso das transferências voluntárias veiculadas por meio de convênios e contratos de repasse, o detalhamento do procedimento de prestação de contas é disciplinado pela Portaria n. 507/2011, cujo artigo 72 estabelece apenas o prazo máximo, que é de 60 (sessenta) dias, remetendo ao convênio a fixação do prazo para a prestação de contas. Nesse sentido, dispõe o artigo:

Art. 72. O órgão ou entidade que receber recursos na forma estabelecida nesta Portaria estará sujeito a prestar contas da sua boa e regular aplicação, observando-se o seguinte:

I - o prazo para apresentação das prestações de contas será de até 60 (sessenta) dias após o encerramento da vigência ou a conclusão da execução do objeto, o que ocorrer primeiro; e

II - o prazo mencionado na alínea anterior constará no convênio.

Assim, o convenente é obrigado a prestar contas no prazo fixado no convênio, mediante a apresentação de relatório de cumprimento de objeto e de uma série de

62 BRASIL. Ministério do Planejamento, Orçamento e Gestão, cit., p. 3. 
documentos pertinentes ao convênio, na forma do artigo 74 da Portaria Interministerial n. 507/2011, ${ }^{63}$ com o objetivo de demonstrar a correção na aplicação dos recursos recebidos. Tanto os documentos relativos ao convênio, como os relativos à prestação de contas deverão ser mantidos pelo período de 10 anos, contados da aprovação da prestação de contas. ${ }^{64}$

Ressalta-se que a inadimplência em virtude da ausência de prestação de contas ou da rejeição das contas prestadas ocasionará a instauração de Tomada de Contas Especial, cuja consequência implica na restrição ao recebimento de novas transferências financeiras mediante convênios, contratos de repasse e termos de cooperação. A matéria é disciplinada pelos artigos $72, \$ 3^{\circ}, 76, \S 2^{\circ}$ e $82, \$ 3^{\circ}$, que cuidam, respectivamente, da omissão do dever de prestar contas, da não aprovação das contas e da tomada de contas especial:

Art. 72. (...)

$\$ 3^{\circ} \mathrm{Se}$, ao término do prazo estabelecido, o convenente não apresentar a prestação de contas nem devolver os recursos nos termos do $₫ 1^{\circ}$, o concedente registrará a inadimplência no SICONV por omissão do dever de prestar contas e comunicará o fato ao órgão de contabilidade analítica a que estiver vinculado, para fins de instauraçáo de tomada de contas especial sob aquele argumento e adoção de outras medidas para reparação do dano ao erário, sob pena de responsabilização solidária.

63 Dispõem o artigo 74 e seus incisos: Art. 74. A prestação de contas será composta, além dos documentos e informaçōes apresentados pelo convenente no SICONV, do seguinte: I - Relatório de Cumprimento do Objeto; II - Notas e comprovantes fiscais, quanto aos seguintes aspectos: data do documento, compatibilidade entre o emissor e os pagamentos registrados no SICONV, valor, aposição de dados do convenente, programa e número do convênio; III - Relatório de prestação de contas aprovado e registrado no SICONV pelo convenente; IV - declaração de realização dos objetivos a que se propunha o instrumento; $\mathrm{V}$ - relação de bens adquiridos, produzidos ou construídos, quando for o caso; VI - a relação de treinados ou capacitados, quando for o caso; VII - a relação dos serviços prestados, quando for o caso; VIII - comprovante de recolhimento do saldo de recursos, quando houver; e IX - termo de compromisso por meio do qual o convenente será obrigado a manter os documentos relacionados ao convênio, nos termos do $₫ 3^{\circ}$ do art. $3^{\circ}$ desta Portaria.

Dispõem o artigo $3^{\circ}$ e seus parágrafos: Art. $3^{\circ}$ Os atos e os procedimentos relativos à formalização, execução, acompanhamento, prestação de contas e informações acerca de tomada de contas especial dos convênios e termos de parceria serão realizados no Sistema de Gestão de Convênios e Contratos de Repasse - SICONV, aberto à consulta pública, por meio do Portal dos Convênios.

$\$ 1^{\circ}$ Os atos que, por sua natureza, não possam ser realizados no SICONV, serão nele registrados. $\$ 2^{\circ}$ Para a celebração dos instrumentos regulados por esta Portaria, os órgãos, entidades e entes a que se refere o art. $1^{\circ}$ devem estar cadastrados no SICONV.

$\$ 3^{\circ} \mathrm{O}$ convenente deverá manter os documentos relacionados ao convênio pelo prazo de 10 (dez) anos, contados da data em que foi aprovada a prestação de contas. (...) 
Art. 76. (...)

$\$ 2^{\circ}$ Caso a prestação de contas não seja aprovada, exauridas todas as providências cabíveis para regularização da pendência ou reparação do dano, a autoridade competente, sob pena de responsabilização solidária, registrará o fato no SICONV e adotará as providências necessárias à instauração da Tomada de Contas Especial, com posterior encaminhamento do processo à unidade setorial de contabilidade a que estiver jurisdicionado para os devidos registros de sua competência.

Art. 82. (...)

\section{$\S 3^{\circ} \mathrm{A}$ instauração de Tomada de Contas Especial ensejará:}

I - a inscrição de inadimplência do respectivo instrumento no SICONV, o que será fator restritivo a novas transferências de recursos financeiros oriundos do Orçamento Fiscal e da Seguridade Social da União mediante convênios, contratos de repasse e termos de cooperação, nos termos do inciso V do art. 10 desta Portaria; e

II - o registro daqueles identificados como causadores do dano ao erário na conta “DIVERSOS RESPONSÁVEIS” do SIAFI. (Grifo nosso)

Consiste a tomada de contas em "um processo devidamente formalizado, dotado de rito próprio, que objetiva apurar os fatos, identificar os responsáveis e quantificar o dano causado ao erário, com o objetivo de seu imediato ressarcimento". ${ }^{65}$ Ainda de acordo com a Cartilha SICONV para os Municípios:

(...) a simples instauração da TCE enseja a inscrição do Município como inadimplente no Siconv, o que caracteriza a restrição ao recebimento de novas transferências de recursos financeiros oriundos do Orçamento Fiscal e da Seguridade Social da União por meio de convênios e contratos de repasse. ${ }^{66}$

A competência para a instauração da Tomada de Contas Especial recai na autoridade competente do órgão concedente ou, ainda, "por determinação dos órgãos de Controle Interno ou do Tribunal de Contas da União, no caso de omissão da autoridade competente em adotar essa medida" (art. 82, $\$ 2^{\circ}$, da Portaria $n$. 507/2011). Ainda conforme informações constantes da Cartilha do SICONV:

Compete ao novo prefeito apresentar as contas referentes aos recursos federais recebidos por seu antecessor, quando este não o tiver feito. Se não houver meios de efetivar a prestação de contas do antecessor, por exemplo, por falta de documentação exigível, ele deverá adotar as medidas legais visando o resguardo do patrimônio público, com a instauração da competente Tomada de Contas Especial - TCE, sob pena de co-responsabilidade. ${ }^{67}$

65 BRASIL. Ministério do Planejamento, Orçamento e Gestão, cit., p. 9.

66 BRASIL. Ministério do Planejamento, Orçamento e Gestão, cit., p. 9.

67 BRASIL. Ministério do Planejamento, Orçamento e Gestão, cit., p. 8. 
Assim, no tocante à prestação de contas relativas aos ajustes celebrados com Estados ou Municípios, como é a hipótese das transferências voluntárias reguladas pelo artigo 25 da Lei de Responsabilidade Fiscal, sobressai a obrigação dos gestores que assumem o cargo após a celebração do convênio de prestar as contas, uma vez que eles respondem pela obrigação mesmo que o convênio não tenha sido celebrado sob sua gestão, e ainda que a execução tenha se encerrado anteriormente ao seu início. O procedimento vem descrito no $\$ \$ 4^{\circ}$ a $6^{\circ}$ do artigo 72 da Portaria Interministerial n. 507/2011:

Art. 72. (...)

$\$ 4^{\circ}$ Cabe ao prefeito e ao governador sucessor prestar contas dos recursos provenientes de convênios firmados pelos seus antecessores.

$\$ 5^{\circ} \mathrm{Na}$ impossibilidade de atender ao disposto no parágrafo anterior, deverá apresentar ao concedente justificativas que demonstrem o impedimento de prestar contas e as medidas adotadas para o resguardo do patrimônio público.

$\$ 6^{\circ}$ Quando a impossibilidade de prestar contas decorrer de ação ou omissão do antecessor, o novo administrador solicitará ao concedente a instauração de tomada de contas especial.

No mesmo sentido, corroborando a necessidade de dar início ao procedimento de tomada de contas, estatui o artigo $8^{\circ}$, caput, da Lei Orgânica do Tribunal de Contas da União (Lei Federal n. 8.443/92):

Art. $8^{\circ}$ Diante da omissão no dever de prestar contas, da não comprovação da aplicação dos recursos repassados pela União, na forma prevista no inciso VII do art. $5^{\circ}$ desta Lei, da ocorrência de desfalque ou desvio de dinheiros, bens ou valores públicos, ou, ainda, da prática de qualquer ato ilegal, ilegítimo ou antieconômico de que resulte dano ao Erário, a autoridade administrativa competente, sob pena de responsabilidade solidária, deverá imediatamente adotar providências com vistas à instauração da tomada de contas especial para apuração dos fatos, identificação dos responsáveis e quantificação do dano.

A esse propósito, por fim, foi editada a Súmula 230 do Tribunal de Contas da Uniāo, segundo a qual:

Compete ao prefeito sucessor apresentar as contas referentes aos recursos federais recebidos por seu antecessor, quando este não o tiver feito ou, na impossibilidade de fazê-lo, adotar as medidas legais visando ao resguardo do patrimônio público com a instauração da competente Tomada de Contas Especial, sob pena de co-responsabilidade. 


\subsection{TRANSFERÊNCIAS VOLUNTÁRIAS POR MEIO DE EMENDAS PARLAMENTARES E OBSERVÂNCIA DAS REGRAS PROCEDIMENTAIS ORDINÁRIAS RELATIVAS ÀS TRANSFERÊNCIAS VOLUNTÁRIAS}

As emendas parlamentares aparecem como um importante instrumento de consecução das transferências voluntárias, estando inseridas em um contexto de negociações entre o Poder Executivo e o Poder Legislativo, consistindo também em um dos mecanismos de governabilidade. Contudo, ainda que decorrentes de inserções parlamentares efetuadas ao orçamento, as transferências decorrentes de emendas devem seguir o procedimento ordinário de formalização, inclusive com a apresentação de propostas pelos entes contemplados por emendas junto ao SICONV, não dispensando, da mesma maneira, a outorga de contrapartida pelos entes convenentes.

Nesse sentido, à guisa de exemplo, extrai-se do Manual de Instruções ao Proponente de Emenda Parlamentar, elaborado pela Secretaria de Desenvolvimento da Produção do Ministério do Desenvolvimento, Indústria e Comércio Exterior, especificamente quanto ao Programa SICONV n. 2800020130003: Promoção do Desenvolvimento Industrial - Apoio aos APLs e às Cadeias Produtivas:

Para ser possível a inserção de propostas para esse programa é imprescindível existir indicação parlamentar do Município, Estado ou Distrito Federal nas emendas parlamentares feitas aos Orçamentos Anuais da União (LOA). Essas indicações podem ser de Deputados Federais, Senadores e Comissões dessas duas casas, separadamente ou concomitantemente. No caso do ano vigente, 2013, somente serão aceitas propostas de Municípios, Estados ou Distrito Federal que estejam contemplados nas emendas da Lei Orçamentária Anual de 2013. Os números de CNPJ dos possíveis proponentes estarão previamente cadastrados no SICONV, o que fará com que somente estes possam incluir propostas para esse programa. Cabe destacar que não se trata de Proposta Voluntária e sim de Proposta de Proponente de Emenda Parlamentar. Ou seja, este Ministério não possui recursos diretos para esse programa. Outra questão importante a ser frisada é que, mesmo havendo a indicação parlamentar, não existe garantia do repasse de recursos. Isso se dá, pois o repasse de recursos somente ocorrerá se houver dotação orçamentária e disponibilidade financeira para tal e caso o proponente tenha atendido todas as exigências legais e as demais solicitadas pela Administração Federal. Caso sua municipalidade/ estado/ DF não tenha sido contemplado no Orçamento vigente, sugerimos que verifique junto ao Poder Legislativo local como proceder para possível indicação nos próximos orçamentos. Assim, seguem, em destaque, a quem se destina esse programa: ADMINISTRAÇÃO 


\section{PÚBLICA MUNICIPAL; ADMINISTRAÇÃO PÚBLICA ESTADUAL; DIS- TRITO FEDERAL. ${ }^{68}$}

Nesse sentido, segue exemplo de proposta apresentada pelo Município de Epitaciolândia que antecedeu a celebração de contrato de repasse n. 807271/2014, celebrado entre a União, por intermédio do Ministério do Desenvolvimento Agrário, e o Município acreano:

Epitaciolândia é um Município do Estado do Acre e situa-se à margem direita do rio Acre, o Município abriga marcos de fronteira estabelecidos para esclarecer os limites com a Bolívia, possui uma forte ligação econômica com a cidade vizinha de Cobija (Bolívia) através da ponte do Igarapé Bahia e mantém um grande intercâmbio comercial com a vizinha Brasiléia, através de uma ponte sobre o Rio Acre. Fica localizado a $230 \mathrm{~km}$ da capital do Estado com acesso direto pela rodovia federal 317, tem aproximadamente 16.099 habitantes e seu IDH é de 0,653. Grande parte da população, 5247 mora na zona rural, e a garantia de uma boa infraestrutura dos ramais é imprescindível para a viabilização do processo de desenvolvimento local, cumprindo importante papel na execução das atividades de desenvolvimento rural sustentável. O Município tem sua economia baseada na Agricultura de subsistência e na pecuária e no extrativismo vegetal. Nos últimos anos o Município tem firmado parcerias importantes com o Governo Federal e Estadual, e como resultado a agricultura já começa a apresentar melhores índices, dentre os quais a comercialização de produtos como a mandioca, o arroz, a melancia e o feijão, ou seja, com os investimentos feitos até agora já se vê uma significativa melhora na economia do Município e na renda do pequeno produtor. Sendo a agricultura a principal atividade econômica do Município, é necessário que o Poder Público Municipal ofereça serviços de infraestrutura adequados e compatíveis com as atividades rurais principalmente nos serviços que garantam o escoamento dessa produção rural, oferecendo a esses produtores melhores condições de mobilidade para que os mesmos possam comercializar a sua produção diretamente no mercado consumidor sem a presença constante do atravessador. Esse projeto de Aquisição de 02 (dois) caminhões agrícolas irão fortalecer os serviços de transporte para os produtores rurais que dependem do Município para fazer o transporte de sua produção e a melhoria dos ramais da região. Os recursos ora solicitados correspondem ao percentual destinado a este Município referente à Emenda Individual do Deputado Federal pelo Estado do Acre, Senhor Sibá Machado com n. 26870005, com

68 BRASIL. Ministério do Desenvolvimento, Indústria e Comércio Exterior; Coordenação Geral de Arranjos Produtivos Locais; Secretaria de Desenvolvimento da Produção. Manual de Instruções ao Proponente de Emenda Parlamentar Programa SICONV n. 2800020130003: Promoção do Desenvolvimento Industrial - Apoio aos APLs e às Cadeias Produtivas. Brasília: Ministério do Desenvolvimento, Indústria e Comércio Exterior, 2013. 
Funcional n. 21.127.2029.210X para Apoio ao Desenvolvimento Sustentável de Territórios Rurais - Epitaciolândia - AC. ${ }^{69}$

A conclusão apontada se mantém mesmo com a introdução do chamado orçamento impositivo, que torna obrigatória a execução de emendas no limite percentual de 1,2\% da receita corrente líquida, ressalvada a observância do requisito concernente à adimplência dos Estados, Distrito Federal e Municípios, na forma do disposto nos $\$ \$ 9^{\circ}$ a 16 do artigo 166 da Constituição Federal, incluídos no texto constitucional pela Emenda n. 86, de 17 de março de 2015:

Art. 166. (...)

$\$ 9^{\circ}$ As emendas individuais ao projeto de lei orçamentária serão aprovadas no limite de 1,2\% (um inteiro e dois décimos por cento) da receita corrente líquida prevista no projeto encaminhado pelo Poder Executivo, sendo que a metade deste percentual será destinada a ações e serviços públicos de saúde.

$\$ 10$ A execução do montante destinado a ações e serviços públicos de saúde previsto no $\$ 9^{\circ}$, inclusive custeio, será computada para fins do cumprimento do inciso I do $\$$ $2^{\circ}$ do art. 198, vedada a destinação para pagamento de pessoal ou encargos sociais.

$\$ 11$ É obrigatória a execução orçamentária e financeira das programações a que se refere o $\$ 9^{\circ}$ deste artigo, em montante correspondente a 1,2\% (um inteiro e dois décimos por cento) da receita corrente líquida realizada no exercício anterior, conforme os critérios para a execução equitativa da programação definidos na lei complementar prevista no $\$ 9^{\circ}$ do art. 165 .

$\$ 12$ As programaçóes orçamentárias previstas no $\$ 9^{\circ}$ deste artigo não serão de execuçáo obrigatória nos casos dos impedimentos de ordem técnica.

\ 13 Quando a transferência obrigatória da União, para a execução da programação prevista no $\$ 11$ deste artigo, for destinada a Estados, ao Distrito Federal e a Municípios, independerá da adimplência do ente federativo destinatário e não integrará a base de cálculo da receita corrente líquida para fins de aplicação dos limites de despesa de pessoal de que trata o caput do art. 169.

$\$ 14$ No caso de impedimento de ordem técnica, no empenho de despesa que integre a programação, na forma do $\$ 11$ deste artigo, serão adotadas as seguintes medidas:

I - até 120 (cento e vinte) dias após a publicação da lei orçamentária, o Poder Executivo, o Poder Legislativo, o Poder Judiciário, o Ministério Público e a Defensoria Pública enviarão ao Poder Legislativo as justificativas do impedimento;

69 BRASIL. Contrato de Repasse entre o Município de Epitaciolândia e o Ministério do Desenvolvimento Agráfico n. 807.271/2014, de 14 ago. 2014. Diário Oficial da União, Brasília, 25 ago. 2014. Grifo nosso. 
II - até 30 (trinta) dias após o término do prazo previsto no inciso I, o Poder Legislativo indicará ao Poder Executivo o remanejamento da programação cujo impedimento seja insuperável;

III - até 30 de setembro ou até 30 (trinta) dias após o prazo previsto no inciso II, o Poder Executivo encaminhará projeto de lei sobre o remanejamento da programação cujo impedimento seja insuperável;

IV - se, até 20 de novembro ou até 30 (trinta) dias após o término do prazo previsto no inciso III, o Congresso Nacional não deliberar sobre o projeto, o remanejamento será implementado por ato do Poder Executivo, nos termos previstos na lei orçamentária.

$\$ 15$ Após o prazo previsto no inciso IV do $\$ 14$, as programações orçamentárias previstas no $₫ 11$ não serão de execução obrigatória nos casos dos impedimentos justificados na notificação prevista no inciso I do $\$ 14$.

$\$ 16$ Os restos a pagar poderão ser considerados para fins de cumprimento da execução financeira prevista no $\$ 11$ deste artigo, até o limite de $0,6 \%$ (seis décimos por cento) da receita corrente líquida realizada no exercício anterior.

$\$ 17$ Se for verificado que a reestimativa da receita e da despesa poderá resultar no não cumprimento da meta de resultado fiscal estabelecida na lei de diretrizes orçamentárias, o montante previsto no $\$ 11$ deste artigo poderá ser reduzido em até a mesma proporção da limitação incidente sobre o conjunto das despesas discricionárias.

$\$ 18$ Considera-se equitativa a execução das programações de caráter obrigatório que atenda de forma igualitária e impessoal às emendas apresentadas, independentemente da autoria. (Grifo nosso)

Nesse sentido, observa-se especialmente o teor do $\$ 13$, que afasta o requisito relativo à adimplência dos convenentes - Estados, Distrito Federal e Municípios exigência esta inerente à sistemática das transferências voluntárias de recursos. Tal comando diferencia as transferências voluntárias de recursos veiculadas por meio de emendas parlamentares de execução obrigatória das demais transferências voluntárias, decorrentes de emendas parlamentares ou não.

Outro ponto que merece destaque relaciona-se ao $\$ 12$, que afasta o caráter obrigatório das emendas na hipótese de impedimentos de ordem técnica. Como panorama ilustrativo das principais modalidades de impedimentos de natureza técnica verificados na prática, bem como a frequência de sua ocorrência, destaca-se o teor de tabela relativa ao exercício de 2014, extraída do Boletim das Emendas parlamentares, publicado pela Câmara dos Deputados: 


\section{Quadro 5.4 Panorama ilustrativo das principais modalidades de impedimentos} técnicos para execução de emendas

\begin{tabular}{|c|c|c|}
\hline JUSTIFICATIVAS & FREQUÊNCIA & PORCENTAGEM \\
\hline Não apresentação do plano de trabalho no prazo & 798 & $38,70 \%$ \\
\hline $\begin{array}{l}\text { Falta de razoabilidade dos valores: incompatibilidade do valor } \\
\text { proposto com o cronograma de execução do projeto ou proposta } \\
\text { de valor que impeça a conclusão de uma etapa útil do projeto; não } \\
\text { apresentação do plano de trabalho no prazo }\end{array}$ & 486 & $23,60 \%$ \\
\hline $\begin{array}{l}\text { Falta de razoabilidade dos valores: incompatibilidade do valor } \\
\text { proposto com o cronograma de execução do projeto ou proposta } \\
\text { de valor que impeça a conclusão de uma etapa útil do projeto }\end{array}$ & 317 & $15,40 \%$ \\
\hline Outros & 184 & $8,90 \%$ \\
\hline $\begin{array}{l}\text { Não atendimento dos ajustes solicitados pelos ministérios aos } \\
\text { estados, Municípios e entidades privadas no prazo }\end{array}$ & 136 & $6,60 \%$ \\
\hline Não aprovação do plano de trabalho & 55 & $2,70 \%$ \\
\hline $\begin{array}{l}\text { Não apresentação do plano de trabalho no prazo; não atendimento } \\
\text { dos ajustes solicitados pelos ministérios aos estados, Municípios e } \\
\text { entidades privadas no prazo }\end{array}$ & 30 & $1,50 \%$ \\
\hline $\begin{array}{l}\text { Incompatibilidade do objeto indicado com a finalidade da ação } \\
\text { orçamentária }\end{array}$ & 18 & $0,90 \%$ \\
\hline $\begin{array}{l}\text { Não indicação do beneficiário e respectivo valor da emenda no } \\
\text { prazo estabelecido }\end{array}$ & 14 & $0,70 \%$ \\
\hline Desistência do proponente & 14 & $0,70 \%$ \\
\hline $\begin{array}{l}\text { Outros; não atendimento dos ajustes solicitados pelos ministérios } \\
\text { aos estados, Municípios e entidades privadas no prazo }\end{array}$ & 11 & $0,50 \%$ \\
\hline Total & 2.063 & $100 \%$ \\
\hline
\end{tabular}

Fonte: BRASIL. Câmara dos Deputados; Consultoria de Orçamento e Fiscalização Financeira. Boletim de emendas parlamentares: execução orçamentária e financeira. Brasília: Câmara dos Deputados, ano 1, n. 1, jun. 2015, p. 19.

Assim, diante da introdução das emendas parlamentares de caráter obrigatório no ordenamento jurídico, surge o questionamento quanto à natureza das transferências a elas relacionadas. Em outras palavras, questiona-se se perdura o caráter voluntário ou se, ao contrário, a própria transferência tem sua natureza alterada, passando a constituir uma transferência legal.

Em princípio, entendemos que a transferência continua sendo de natureza voluntária, não obstante prevista em lei - lei orçamentária anual - e não submetida 
ao requisito de adimplência dos entes federados. Com efeito, apesar de prevista legalmente, trata-se de uma disposição pontual, válida para um exercício específico, cuja realização se sujeita a algumas condicionantes, como é o caso dos requisitos de ordem técnica, na medida em que a transferência perde o caráter obrigatório quando surgir algum impedimento de tal natureza. Assim, diante da hipótese de impedimento, caso o mesmo não seja sanado, os recursos serão remanejados. Observa-se, ainda, que o afastamento do requisito atinente à adimplência dos convenentes é válido apenas para os Estados, Distrito Federal e Municípios, não alcançando as entidades da sociedade civil. Permanecem, assim, as transferências decorrentes da execução de emendas individuais de execução obrigatória com natureza de transferências voluntárias.

\subsection{VEDAÇÃO À REALIZAÇÃO DE TRANSFERÊNCIAS VOLUNTÁRIAS EM PERÍODO ELEITORAL}

A potencialidade de que dispõem as transferências voluntárias para influenciar diretamente o resultado dos pleitos eleitorais se evidencia de tal forma que a própria Lei Eleitoral (Lei Federal n. 9.504/97), em uma das raras previsões legais expressas acerca das transferências voluntárias, vedou a realização, nos três meses que antecedem o pleito, de transferência voluntária de recursos da União aos Estados e Municípios, e dos Estados aos Municípios, sob pena de nulidade de pleno direito, ressalvados os recursos destinados a cumprir obrigação formal preexistente para execução de obra ou serviço em andamento e com cronograma prefixado, e os destinados a atender situações de emergência e de calamidade pública (artigo 73, inciso VI). ${ }^{70}$

Estabelece o caput do artigo 73 da Lei Federal n. 9.504/97, que são “vedadas condutas tendentes a afetar a igualdade de oportunidades entre partidos nos pleitos eleitorais". Consoante entendimento jurisprudencial, a mera prática da conduta já

70 Dispõe o artigo 73: Art. 73. São proibidas aos agentes públicos, servidores ou não, as seguintes condutas tendentes a afetar a igualdade de oportunidades entre candidatos nos pleitos eleitorais: (...)

VI - nos três meses que antecedem o pleito:

a) realizar transferência voluntária de recursos da União aos Estados e Municípios, e dos Estados aos Municípios, sob pena de nulidade de pleno direito, ressalvados os recursos destinados a cumprir obrigação formal preexistente para execução de obra ou serviço em andamento e com cronograma prefixado, e os destinados a atender situações de emergência e de calamidade pública; (...). 
configura a infração, sendo desnecessária a efetiva prova da lesividade. Nesse sentido, restou afirmado pelo Tribunal Superior Eleitoral (TSE) que:

(...) a configuração das condutas vedadas prescritas no art. 73 da Lei n. 9.504/97 se dá com a mera prática de atos, desde que esses se subsumam às hipóteses ali elencadas, porque tais condutas, por presunção legal, são tendentes a afetar a igualdade de oportunidades entre os candidatos no pleito eleitoral, sendo desnecessário comprovar-lhes a potencialidade lesiva. ${ }^{71}$

A única ressalva consiste nas condutas elencadas que, pela própria dicção dos respectivos dispositivos, exigem a intenção de beneficiar determinada candidatura, tais como aquelas elencadas nos incisos I e IV do artigo $73 .^{72}$

Assim, a medida visa a evitar o uso das transferências voluntárias com o fim de conceder vantagens eleitorais para determinados candidatos ou partidos políticos. Contudo, a vedação imposta pela legislação eleitoral não se mostra muito efetiva, ante o fato de que a restrição se limita ao período de três meses anteriores ao pleito, não resvalando na liberação de parcelas decorrentes de acordos anteriormente celebrados. Dessa forma, ainda que se possa perceber certa constrição à realização de transferências voluntárias no período, tais restrições não se mostram efetivamente hábeis a refrear o volume de transferências voluntárias especialmente em anos eleitorais.

Da análise das transferências realizadas nos últimos exercícios, verifica-se um volume maior de transferências realizado justamente no ano eleitoral de 2010 - volume total de R \$ 13.948.861.000, sendo R \$ 5.981.171.000 destinados aos Estados e R 7.967.690.000 aos Municípios. Já no ano de 2011, houve um decréscimo de tal volume - volume total de $\mathrm{R} \$$ 9.882.917.000, sendo $\mathrm{R} \$ 3.701 .343 .000$ destinados

71 BRASIL. Tribunal Superior Eleitoral, Tribunal Pleno. Recurso Especial Eleitoral n. 45.060 Corinto/MG. Relatora: Ministra Laurita Hilário Vaz. Brasília, 26 set. 2013. DJe 203, 22 out. 2013, p. 55-56.

72 Mencionados dispositivos cuidam, respectivamente, da cessão ou uso de bens pertencentes à administração, bem como da distribuição gratuita de bens em favor de candidato, partido ou coligação, nos seguintes termos:

Art. 73. São proibidas aos agentes públicos, servidores ou não, as seguintes condutas tendentes a afetar a igualdade de oportunidades entre candidatos nos pleitos eleitorais:

I - ceder ou usar, em benefício de candidato, partido político ou coligação, bens móveis ou imóveis pertencentes à administração direta ou indireta da União, dos Estados, do Distrito Federal, dos Territórios e dos Municípios, ressalvada a realização de convenção partidária; (...)

IV - fazer ou permitir uso promocional em favor de candidato, partido político ou coligação, de distribuição gratuita de bens e serviços de caráter social custeados ou subvencionados pelo Poder Público; (...) 
aos Estados e R\$ 6.181.574.000 aos Municípios. Nos exercícios de 2012 e 2013, o volume se manteve estável:

a) $2012-\mathrm{R} \$$ 11.904.344.000, dos quais $\mathrm{R} \$ 4.503 .324 .000$ aos Estados e $\mathrm{R} \$$ 7.401.020.000 aos Municípios;

b) $2013-\mathrm{R} \$ 11.641 .070 .000$, dos quais $\mathrm{R} \$ 3.539 .037 .000$ aos Estados e $\mathrm{R} \$$ 8.102.034.000 aos Municípios.

Mesmo durante o exercício de 2014, o montante de transferências manteve uma leve queda, mas muito tênue em relação aos exercícios anteriores, alcançando-se os seguintes números: $\mathrm{R} \$ 11.151 .285 .000$, no total, dos quais $\mathrm{R} \$ 3.058 .104 .000$ aos Estados e R\$ 8.093.181.000 aos Municípios.

Dessa forma, verifica-se que a vedação não possui maiores impactos em números absolutos no período eleitoral, não se refletindo, aparentemente, com base em dados comparativos com os exercícios anteriores, na inibição da utilização das transferências voluntárias com um viés eleitoral.

O descumprimento da vedação acarretará a suspensão imediata da conduta e será aplicada multa aos responsáveis, além de se possibilitar a cassação do registro da candidatura ou do diploma do eleito, entre outras sanções cabíveis.

O próprio dispositivo legal elenca as exceções aplicáveis à vedação das transferências voluntárias em período eleitoral, quais sejam: a) a transferência de recursos destinados a cumprir obrigação formal preexistente para execução de obra ou serviço já fisicamente iniciados e com cronograma prefixado; b) a transferência de recursos destinados a atender situaçôes de emergência e de calamidade pública.

Consoante extraído da cartilha elaborada pela Advocacia Geral da União, mencionando decisões judiciais a este respeito, também não são abrangidos pela proibição os repasses para entidades privadas. Esta não se trata propriamente de exceção criada pela jurisprudência, mas sim de interpretação emprestada ao dispositivo no sentido de que a vedação se encontra restrita às transferências efetuadas entre os entes da federação. Conforme restou decidido pelo Tribunal Superior Eleitoral, tendo em vista a natureza restritiva contida na regra do artigo 73 , inciso VI, $a$, não cabe interpretação extensiva da vedação, em evidente aplicação da máxima jurídica de que as regras restritivas devem ser interpretadas restritivamente. Dessa forma, consoante jurisprudência pacificada do Tribunal, eventuais transferências realizadas pelos entes federados a entidades particulares não configurariam a vedação disposta no mencionado inciso, restando afastada eventual alegação de nulidade acoimada à conduta.

Isso não significa, no entanto, que a realização de transferências efetuadas pelos entes federados com o fim de favorecimento de determinado candidato ou 
partido político não possa sofrer consequências jurídicas, na medida em que, em tese, estaria configurada hipótese de abuso de poder econômico ou do poder de autoridade, tal como previsto pelo artigo 22, caput da Lei Complementar n. 64, de 18 de maio de 1990, a chamada Lei das Inelegibilidades. ${ }^{73}$ Nesse sentido, parecer da Procuradoria Geral Eleitoral, mencionado em acórdão do Tribunal Superior Eleitoral, ao reconhecer a inexistência de transgressão ao disposto no artigo 73, inciso VI, alínea $a$, opinou que "os fatos se enquadram na Lei Complementar $\mathrm{n}$. 64/90, configurando abuso de poder econômico e político, em detrimento da liberdade de voto". ${ }^{74}$

No tocante às exceções, convém ressaltar o entendimento que vem sendo emprestado ao dispositivo, particularmente quanto ao conceito de "obras ou serviço em andamento", havendo reiterada jurisprudência no sentido de que a exceção somente se aplicaria aos serviços e obras fisicamente iniciados (Consulta TSE n. 1062).$^{75}$ Por seu turno, no tocante à exceção relativa às situações de emergência e calamidade pública, registra-se entendimento do TSE no sentido da impossibilidade de se realizarem transferências voluntárias a entes da federação que não mais se encontram em situação de emergência ou estado de calamidade, ainda que estejam sofrendo as consequências do referido período.

Convém, ainda, apontar para entendimento da Advocacia Geral da União, exarado no Parecer n. GQ-158, de que os atos preparatórios que antecedem as transferências não estão vedados pela lei, considerando-se legítima a assinatura de convênios, acordos ou instrumentos congêneres, não compreendendo assim a realização de

73 Dispõe o caput do mencionado artigo 22: Art. 22. Qualquer partido político, coligação, candidato ou Ministério Público Eleitoral poderá representar à Justiça Eleitoral, diretamente ao Corregedor-Geral ou Regional, relatando fatos e indicando provas, indícios e circunstâncias e pedir abertura de investigação judicial para apurar uso indevido, desvio ou abuso do poder econômico ou do poder de autoridade, ou utilização indevida de veículos ou meios de comunicação social, em benefício de candidato ou de partido político, obedecido o seguinte rito: (...)

74 BRASIL. Tribunal Superior Eleitoral, Tribunal Pleno. Recurso Especial Eleitoral n. 16.040 Cuiabá/MT. Relator: Ministro Walter Ramos da Costa Porto. Brasília, 11 nov. 1999. DJ, 4 fev. 2000, Seção Única, p. 30.

75 BRASIL. Tribunal Superior Eleitoral, Tribunal Pleno. Consulta n. 1062 Distrito Federal. Resolução n. 21.878, de 12 ago. 2004. Relator: Ministro Carlos Mário da Silva Velloso. DJ, Brasília, 16 set. 2004, v. 1, p. 76; BRASIL. Tribunal Superior Eleitoral, Tribunal Pleno. Recurso Especial Eleitoral n. 25.324 Vassouras/RJ. Relator: Ministro Gilmar Ferreira Mendes. Brasília, 7 fev. 2006. DJ, 17 fev. 2006, p. 126; BRASIL. Tribunal Superior Eleitoral, Tribunal Pleno. Consulta n. 1.119 Distrito Federal. Resolução n. 21.908, de 31 ago. 2004. Relator: Ministro Francisco Peçanha Martins. DJ, Brasília, 20 set. 2004, v. 1, p. 95. 
novos convênios, mas apenas a efetiva transferência de recursos. A esse respeito, menciona Luiz Alberto da Silva, Consultor da União subscritor do parecer:

29. Em razão do que se acabou de afirmar, considero absolutamente legítimo que, durante os três meses que antecedem as eleiçôes, os agentes públicos pratiquem todos os atos preparatórios necessários ao início de uma obra ou serviço, incluindo a assinatura do convênio, acordo ou instrumento congênere, pois nenhum desses atos se encontra proibido pelo art. 73. Não se pode admitir, tal como já se viu, que se interprete a lei nela inserindo proibições que não existem, levando ao absurdo de obrigar a Administração a cruzar os braços, aguardando o término do período para, somente aí, começar a praticar os atos preparatórios.

30. Como afirmei, esses atos preparatórios, inclusive a assinatura do instrumento próprio, podem ser legalmente praticados. Para deixar evidente que não se está descumprindo qualquer proibição legal, o convênio, acordo ou instrumento congênere deverá conter cláusula que explicite que os recursos somente serão liberados, ou seja, a transferência dos recursos somente ocorrerá, após o término do prazo previsto no inciso VI, alínea a, do art. 73 da Lei n. 9.504/97. E isso porque a única proibição que aí existe é quanto à transferência de recursos.

Tal entendimento, contudo, não se apresenta de forma pacífica. A Advocacia-Geral do Estado de Minas Gerais expressa posicionamento consolidado em sentido contrário, emprestando uma abrangência maior ao conceito. Consoante a Nota Técnica n. 2.942, de $1^{\circ}$ de setembro de 2011:

a vedação de realização de transferência voluntária no período eleitoralmente vedado apanha não só a transferência de recursos ou a execução do convênio em si, já firmado, mas também implica em proibição de assinatura de convênios novos ou aditamento de convênios no período eleitoral, seja com o próprio Município seja com entidades da administração indireta municipal (Nota Jurídica 1.278, de 02.10.06; Nota Jurídica 1.724, de 22.08.08; Nota Jurídica 553, de 23.08.04; Nota Jurídica 1.166, de 07.06.06; Nota Jurídica 1.247, de 24.08.06). ${ }^{76}$

Essa nos parece, efetivamente, a solução mais próxima aos objetivos da lei eleitoral, no sentido de vedar a prática de condutas que tendam a afetar a igualdade de oportunidades entre os candidatos, sendo indiscutível a probabilidade de repercussão eleitoral diante da mera assinatura de convênios objetivando a transferência voluntária de recursos.

76 MINAS GERAIS. Advocacia-Geral do Estado. Nota Técnica n. 2.942, de $1^{\circ}$ de setembro de 2011. Eleições Municipais de 2012. Repasse de bens, valores e serviços por parte do Estado a Município e a entidades privadas sem fins lucrativos. Vedação eleitoral. Art. 73, VI, $a$, e $\$ \$ 10$ e 11, da Lei n. 9.504/97. Entendimento consolidado na Consultoria Jurídica do Estado: Parecer 15.000, de 19.03.2010. Disponível em: <http://saida.convenios.mg.gov.br/images/pareceres/parecer_age_2942_repasse_eleicoes_2012.pdf>. Acesso em: 18 dez. 2015. 


\subsection{TRANSFERÊNCIAS INSERIDAS NO PROGRAMA DE ACELERAÇÃO DO CRESCIMENTO: TRANSFERÊNCIAS OBRIGATÓRIAS}

O Programa de Aceleração do Crescimento (PAC) foi lançado pelo Governo Federal em 2007, com o fim de desenvolver projetos voltados ao planejamento de execução de grandes obras de infraestrutura, concernentes ao desenvolvimento econômico e social. Nessa medida, merecem destaque notadamente os programas relacionados à infraestrutura urbana, logística e energética, além do enfoque social, especialmente por conta das obras relacionadas à moradia e transporte.

Como forma de viabilizar a união de esforços entre os entes federados para a consecução dos objetivos do programa, visando à efetivação dos princípios da eficiência e do interesse público, um dos pontos que merecem destaque para efeitos do presente trabalho, no contexto do PAC, reside nas chamadas "transferências voluntárias obrigatórias”. Por meio delas, os entes federados, em especial a União, passaram a contar com mais uma modalidade de transferência legal, nos moldes preconizados pela Lei Federal n. 11.578, de 26 de novembro de 2007, que dispõe sobre a transferência obrigatória de recursos financeiros para a execução pelos Estados, Distrito Federal e Municípios de ações do Programa de Aceleração do Crescimento (PAC), além de disciplinar a forma de operacionalização do Programa de Subsídio à Habitação de Interesse Social (PHS), nos exercícios de 2007 e 2008.

Mencionado diploma remete ao Comitê Gestor do Programa de Aceleração do Crescimento propor ao Poder Executivo as ações do PAC a serem executadas por meio da transferência obrigatória de recursos (art. $\left.2^{\circ}\right) .{ }^{77}$ Com base na competência que lhe foi atribuída, o Poder Executivo editou sucessivamente uma série de decretos discriminando ações do Programa de Aceleração do Crescimento a serem executadas por meio de transferência obrigatória, iniciada com o Decreto Federal n. 6.276, de 28 de novembro de 2007. A última referência diz respeito ao Decreto Federal n. 8.617, de 29 de dezembro de 2015, que contemplou novas ações a serem financiadas mediante a transferência obrigatória.

Outro dispositivo que merece indicação é o artigo $3^{\circ}$ da Lei Federal n. 11.578/2007, que estatui os requisitos a serem observados pelos entes federados para a obtenção dos recursos disponibilizados para a consecução das ações do PAC:

Dispõe o art. 20 da lei: O Poder Executivo, por proposta do Comitê Gestor do Programa de Aceleração do Crescimento - CGPAC, discriminará as ações do PAC a serem executadas por meio da transferência obrigatória de que trata o art. $1^{\circ}$ desta Lei. 
Art. 30 As transferências obrigatórias para execução das ações do PAC são condicionadas ao cumprimento dos seguintes requisitos pelos Estados, Distrito Federal e Municípios beneficiários, conforme o constante de termo de compromisso:

I - identificação do objeto a ser executado;

II - metas a serem atingidas;

III - etapas ou fases de execução;

IV - plano de aplicação dos recursos financeiros;

$\mathrm{V}$ - cronograma de desembolso;

VI - previsão de início e fim da execução do objeto, bem como da conclusão das etapas ou fases programadas; e

VII - comprovação de que os recursos próprios para complementar a execução do objeto estão devidamente assegurados, salvo se o custo total do empreendimento recair sobre a entidade ou órgão descentralizador, quando a ação compreender obra ou serviço de engenharia.

$\$ 1^{\circ}$ A aprovação formal pela União do termo de compromisso de que trata o caput deste artigo é condição prévia para a efetivação da transferência obrigatória.

$\$ 2^{\circ}$ A cada ação incluída ou alterada no PAC corresponderá um termo de compromisso, a ser apresentado pelo ente federado beneficiado.

Verifica-se, dessa forma, a necessidade de celebração de termo de compromisso entre a União e os demais entes federados que contemple os requisitos do artigo $3^{\circ}$, bem como as responsabilidades decorrentes da celebração do ajuste. Nessa medida, sobressai o papel do termo de compromisso:

(...) como o instrumento jurídico apto a disciplinar transferência obrigatória de recursos financeiros pelos órgãos e entidades da União aos órgãos e entidades dos Estados, Distrito Federal e Municípios para a execução de ações do Programa de Aceleração do Crescimento - PAC cuja execução pelos entes federados seja de interesse da União. ${ }^{78}$

Observa-se, ainda, que muito embora a lei tenha contemplado genericamente as ações do PAC enquanto transferências obrigatórias, a rigor mencionadas transferências

78 Definição sintetizada no Parecer n. 03/2014/CÂMARAPERMANENTECONVÊNIOS/ DEPCONSU/PGF/ AGU, Departamento de Consultoria da Procuradoria Geral da União, cuja conclusão alcançada foi a seguinte: CONCLUSĀO DEPCONSU/PGF/AGU n. 66/2014: "É possível rescindir unilateral ou amigavelmente termo de compromisso, quando restar evidenciado a impossibilidade de conclusão do seu objeto pelo ente federado beneficiado em razão de algum motivo plausível idôneo" (BRASIL. Advocacia-Geral da União; Procuradoria-Geral Federal;DepartamentodeConsultoria.Parecern.03/2014/CÂMARAPERMANENTECONVÊNIOS/ $D E P C O N S U / P G F / A G U$, de 05 jun. 2014. Disponível em: <http://www.agu.gov.br/page/download/index/id/23940141>. Acesso em: 18 dez. 2015). 
não dispõem de tal natureza, uma vez que a definição das ações se dá em âmbito infralegal, consoante programação governamental a cargo do Poder Executivo, voltadas a atuações pontuais. Essa realidade contraria a dinâmica das transferências obrigatórias (constitucionais e legais), que são caracterizadas pela perenidade e pela especificação legal de sua ocorrência, dispensando a celebração de compromisso, na medida em que, via de regra, as transferências legais obrigatórias são efetuadas de forma automática.

As ações do PAC, por sua vez, aproximar-se-iam mais da natureza das transferências voluntárias, mormente no tocante à finalidade de investimentos em infraestrutura, representativas de verdadeiros atos de gestão. No entanto, a sistemática das transferências obrigatórias inseridas no contexto do Programa também as diferenciam das transferências voluntárias propriamente ditas, sujeitas a uma série de requisitos e vedações não aplicáveis à celebração dos termos de compromisso assumidos no âmbito do PAC.

Ao lado dessas ações, é possível apontar algumas medidas pontuais, implementadas por meio de lei, que também contemplam a transferência de recursos de natureza obrigatória, mas com características de transferências voluntárias, efetuadas por meio de convênios. A esse título, menciona-se a Lei Federal n. 12.340, de $1^{\circ}$ de dezembro de 2010, que dispóe sobre as transferências de recursos da União aos órgãos e às entidades dos Estados, Distrito Federal e Municípios para a execução de ações de prevenção em áreas de risco de desastres e de resposta e de recuperação em áreas atingidas por desastres e sobre o Fundo Nacional para Calamidades Públicas, Proteção e Defesa Civil.

O caput do artigo $4^{\circ}$ do mencionado diploma legal, com a redação conferida pela Lei n. 12.983, de 2 de junho de 2014, estabelece a obrigatoriedade da transferência nos seguintes termos:

São obrigatórias as transferências da União aos órgãos e entidades dos Estados, do Distrito Federal e dos Municípios para a execução de ações de prevenção em áreas de risco de desastres e de resposta e de recuperação em áreas atingidas ou com risco de serem atingidas por desastres, observados os requisitos e procedimentos estabelecidos pela legislação aplicável.

Por seu turno, mencionado documento impõe o procedimento a ser observado para a realização da transferência em questão, aproximando-a das transferências voluntárias, na medida em que as transferências obrigatórias não são, em princípio, condicionadas à observância de requisitos por parte dos entes recebedores. Nesse sentido, estabelece o $\$ 2^{\circ}$ do artigo $1^{\circ}$-A:

$\$ 2^{\circ}$ Será responsabilidade exclusiva dos Estados, do Distrito Federal e dos Municípios beneficiados: 
I - demonstrar a necessidade dos recursos demandados;

II - apresentar, exceto nas ações de resposta, plano de trabalho ao órgão responsável pela transferência de recursos, na forma e no prazo definidos em regulamento;

III - apresentar estimativa de custos necessários à execução das ações previstas no caput, com exceção das ações de resposta;

IV - realizar todas as etapas necessárias à execução das ações de prevenção em área de risco e de resposta e de recuperação de desastres, nelas incluídas a contratação e execução das obras ou prestação de serviços, inclusive de engenharia, em todas as suas fases; e

$\mathrm{V}$ - prestar contas das ações de prevenção, de resposta e de recuperação ao órgão responsável pela transferência de recursos e aos órgãos de controle competentes.

Por oportuno, veja-se a dicção do $\$ 11$ do artigo $1^{\circ}$-A , que bem retrata o federalismo cooperativo existente em nosso país ao prever a possibilidade de contribuição dos Estados na elaboração da proposta a ser apresentada à União:

$\$ 11$. Os Estados poderão apoiar a elaboração de termos de referência, planos de trabalho e projetos, cotação de preços, fiscalização e acompanhamento, bem como a prestação de contas de Municípios com população inferior a 50.000 (cinquenta mil) habitantes.

\subsection{OUTROS INSTRUMENTOS DE COOPERAÇÃO ENTRE OS ENTES FEDERADOS}

Ao lado dos convênios, contratos de repasse e termos de parceria, que representam os instrumentos jurídicos por meio dos quais se efetivam as transferências voluntárias de recursos, outros instrumentos jurídicos são utilizados na operacionalização das diversas formas de cooperação administrativa, envolvendo ou não a transferência de recursos. Apesar de não vocacionados à concretização das transferências voluntárias, merecem breve menção, a fim de que sejam distinguidos daqueles dedicados a essas operações.

\subsubsection{Termo de adesão}

Em princípio, o termo de adesão não envolve o repasse de recursos financeiros, mas apenas a vinculação dos órgãos ou das entidades da Administração Pública a uma dada política governamental. Na verdade, pode anteceder eventual transferência de recursos por meio do instrumento adequado.

A título de exemplo, mencione-se o Programa de Aquisição de Alimentos (PAA), veiculado pela Lei Federal n. 10.696, de 2 de julho de 2003, que dispóe 
sobre a repactuação e o alongamento de dívidas oriundas de operações de crédito rural, e dá outras providências, entre as quais a criação do mencionado Programa. Este envolve a alocação de recursos diretamente aos agricultores familiares que dele participam, por intermédio de instituição financeira federal. No entanto, as entidades executoras que aderirem ao PAA também poderão receber apoio financeiro do Governo Federal a fim de contribuir com a operacionalização de metas do Programa. Para tanto, é firmado um termo de adesão, que cuida das obrigações, atribuições e compromissos assumidos pelas partes, além da definição da logística necessária para a gestão e execução do PAA, como estrutura física, recursos humanos e instância de controle social.

Nesse sentido, estabelecem os artigos 20 e 21 da Lei n. 12.512, de 14 de outubro de 2011:

Art. 20. Sem prejuízo das modalidades já instituídas, o PAA poderá ser executado mediante a celebração de Termo de Adesão firmado por órgãos ou entidades da administração pública estadual, do Distrito Federal ou municipal, direta ou indireta, e consórcios públicos, dispensada a celebração de convênio.

Art. 21. Para a execução das açôes de implementação do PAA, fica a União autorizada a realizar pagamentos aos executores do Programa, nas condiçóes específicas estabelecidas em regulamento, com a finalidade de contribuir com as despesas de operacionalização das metas acordadas. (Grifo nosso)

No caso, o próprio termo de adesão já obriga as partes e implica na transferência de recursos, estando dispensada posterior celebração de convênio. Em verdade, não se trata de modalidade de transferência de recursos entre os entes federados, uma vez que o repasse ocorre apenas em decorrência de uma exigência operacional, na medida em que os beneficiários do Programa são os fornecedores ou consumidores de alimentos (art. $3^{\circ}$ do Decreto Federal n. 7.775, de 4 de julho de 2012), e os entes federados ostentam apenas a condição de unidades executoras do Programa (art. 28, inciso I, do Decreto Federal n. 7.775/2012), em um claro exemplo de atuação cooperada entre os entes federados objetivando um fim comum.

Outro exemplo a ser mencionado é o Sistema Nacional de Segurança Alimentar e Nutricional (SISAN), criado pela Lei Federal n. 11.346, de 15 de setembro de 2006, que visa a assegurar o direito humano à alimentação adequada, e regulamentado pelo Decreto Federal n. 7.272, de 25 de agosto de 2010, que institui a Política Nacional de Segurança Alimentar e Nutricional (PNSAN), com o objetivo geral de promover a segurança alimentar e nutricional.

Mencionado decreto prevê, ainda, que a participação dos entes federados no SISAN se dá por meio da formalização de termo de adesão (art. 11). Essa participação 
envolve a destinação de dotação específica para o alcance das finalidades do programa. ${ }^{79}$ Contudo, ainda que se reconheça o caráter voluntário da adesão ao programa, não se trata de modalidade de transferência voluntária de recursos, tendo em vista que não há repasse entre os entes federados, mas sim a destinação orçamentária de recursos com vistas à finalidade perseguida pelo decreto.

\subsubsection{Termo de parceria e contratos de gestão}

Instituído pela Lei Federal n. 9.790, de 23 de março de 1999, o termo de parceria é o instrumento firmado entre o Poder Público e as entidades qualificadas como Organizações da Sociedade Civil de Interesse Público (OSCIP), destinado à formação de vínculo de cooperação entre as partes, para o fomento e a execução de atividades consideradas de interesse público, previstas no art. $3^{\circ}$ da Lei. ${ }^{80}$

79 Dispõem o artigo 14, incisos I e II, e $\$ 1^{\circ}$ : Art. 14. O financiamento da PNSAN será de responsabilidade do Poder Executivo Federal, assim como dos Estados, Distrito Federal e Municípios que aderirem ao SISAN, e se dividirá em:

I - dotaçóes orçamentárias de cada ente federado destinadas aos diversos setores que compóem a segurança alimentar e nutricional; e

II - recursos específicos para gestão e manutenção do SISAN, consignados nas respectivas leis orçamentárias anuais.

$\$ 1^{\circ}$ Os Estados, o Distrito Federal e os Municípios, que aderirem ao SISAN, e o Poder Executivo Federal deverão dotar recursos nos orçamentos dos programas e ações dos diversos setores que compõem a segurança alimentar e nutricional, compatíveis com os compromissos estabelecidos nos planos de segurança alimentar e nutricional e no pacto de gestão pelo direito humano à alimentação adequada. (...)

Dispōem o artigo $3^{\circ}$ da Lei n. 9.790/99 e seus incisos: Art. $3^{\circ}$ A qualificação instituída por esta Lei, observado em qualquer caso, o princípio da universalização dos serviços, no respectivo âmbito de atuação das Organizações, somente será conferida às pessoas jurídicas de direito privado, sem fins lucrativos, cujos objetivos sociais tenham pelo menos uma das seguintes finalidades:

I - promoção da assistência social;

II - promoção da cultura, defesa e conservação do patrimônio histórico e artístico;

III - promoção gratuita da educação, observando-se a forma complementar de participação das organizaçôes de que trata esta Lei;

IV - promoção gratuita da saúde, observando-se a forma complementar de participação das organizações de que trata esta Lei;

$\mathrm{V}$ - promoção da segurança alimentar e nutricional;

VI - defesa, preservação e conservação do meio ambiente e promoção do desenvolvimento sustentável;

VII - promoção do voluntariado;

VIII - promoção do desenvolvimento econômico e social e combate à pobreza;

IX - experimentação, não lucrativa, de novos modelos sócio-produtivos e de sistemas alternativos de produção, comércio, emprego e crédito; 
Nesse sentido, estabelece o artigo $9^{\circ}$ da Lei:

Art. 9० Fica instituído o Termo de Parceria, assim considerado o instrumento passível de ser firmado entre o Poder Público e as entidades qualificadas como Organizaçōes da Sociedade Civil de Interesse Público destinado à formação de vínculo de cooperação entre as partes, para o fomento e a execução das atividades de interesse público previstas no art. $3^{\circ}$ desta Lei.

O instrumento também é previsto pela Portaria Interministerial n. 507/2011, que o define em seu artigo $1^{\circ}, \$ 2^{\circ}$, inciso XXV, como "instrumento jurídico previsto na Lei n. 9.790, de 23 de março de 1999, para transferência de recursos para organizações sociais de interesse público".

Para os efeitos da Lei Federal n. 9.637/98, o contrato de gestão é o instrumento firmado entre o Poder Público e a entidade qualificada como organização social (OS), com vistas a formação de parceria entre as partes para fomento e execução de atividades relativas às áreas dirigidas ao ensino, à pesquisa científica, ao desenvolvimento tecnológico, à proteção e preservação do meio ambiente, à cultura e à saúde.

As entidades qualificadas como organizações sociais - OS (Lei Federal n. 9.637, de 15 de maio de 1998) e as organizações da sociedade civil de interesse público - OSCIP (Lei Federal n. 9.790, de 23 março de 1999) sujeitam-se ao disposto no Decreto Federal n. 5.504, de 5 de agosto de $2005^{81}$ (exigência de licitação

X - promoção de direitos estabelecidos, construção de novos direitos e assessoria jurídica gratuita de interesse suplementar;

XI - promoção da ética, da paz, da cidadania, dos direitos humanos, da democracia e de outros valores universais;

XII - estudos e pesquisas, desenvolvimento de tecnologias alternativas, produção e divulgação de informações e conhecimentos técnicos e científicos que digam respeito às atividades mencionadas neste artigo.

Parágrafo único. Para os fins deste artigo, a dedicação às atividades nele previstas configura-se mediante a execução direta de projetos, programas, planos de ações correlatas, por meio da doação de recursos físicos, humanos e financeiros, ou ainda pela prestação de serviços intermediários de apoio a outras organizaçōes sem fins lucrativos e a órgãos do setor público que atuem em áreas afins."

81 Dispõem o artigo $1^{\circ}$ e seus parágrafos: Art. 10 Os instrumentos de formalização, renovação ou aditamento de convênios, instrumentos congêneres ou de consórcios públicos que envolvam repasse voluntário de recursos públicos da União deverão conter cláusula que determine que as obras, compras, serviços e alienações a serem realizadas por entes públicos ou privados, com os recursos ou bens repassados voluntariamente pela União, sejam contratadas mediante processo de licitação pública, de acordo com o estabelecido na legislação federal pertinente.

$\$ 1^{\circ}$ Nas licitações realizadas com a utilização de recursos repassados nos termos do caput, para aquisição de bens e serviços comuns, será obrigatório o emprego da modalidade pregão, nos 
pública), relativamente aos recursos administrados oriundos de repasses da União em razão de contratos de gestão ou termos de parceria.

Os dois instrumentos não estão abrangidos pelo espectro de análise do presente trabalho, restrito às transferências voluntárias celebradas entre os entes da federação, constituindo as chamadas transferências voluntárias stricto sensu.

\subsubsection{Termo de cooperação}

Outro instrumento jurídico a ser analisado refere-se ao termo de cooperação, definido pelo artigo $1^{\circ}, \$ 2^{\circ}$, inciso XXIV, da Portaria Interministerial n. 507/2011, como "instrumento por meio do qual é ajustada a transferência de crédito de órgão da administração pública federal direta, autarquia, fundação pública, ou empresa estatal dependente, para outro órgão ou entidade federal da mesma natureza”. Vê-se, assim, o uso mais restrito do termo de cooperação, que, por isso mesmo, também não é abrangido pelo presente estudo.

\subsubsection{Termo de colaboração e termo de fomento}

O termo de colaboração e o termo de fomento constituem instrumentos introduzidos pela Lei Federal n. 13.019, de 31 de julho de 2014. Este diploma "estabelece o regime jurídico das parcerias entre a administração pública e as organizações da sociedade civil, em regime de mútua cooperação, para a consecução de finalidades de interesse público e recíproco, mediante a execução de atividades ou de projetos previamente estabelecidos em planos de trabalho inseridos em termos de colaboração, em termos de fomento ou em acordos de cooperação; define dire-

termos da Lei n. 10.520, de 17 de julho de 2002, e do regulamento previsto no Decreto n. 5.450 , de 31 de maio de 2005, sendo preferencial a utilização de sua forma eletrônica, de acordo com cronograma a ser definido em instrução complementar.

$\$ 2^{\circ} \mathrm{A}$ inviabilidade da utilização do pregão na forma eletrônica deverá ser devidamente justificada pelo dirigente ou autoridade competente.

$\$ 3^{\circ}$ Os órgãos, entes e entidades privadas sem fins lucrativos, convenentes ou consorciadas com a União, poderão utilizar sistemas de pregão eletrônico próprios ou de terceiros.

$\$ 4^{\circ}$ Nas situações de dispensa ou inexigibilidade de licitação, as entidades privadas sem fins lucrativos, observarão o disposto no art. 26 da Lei n. 8.666, de 21 de junho de 1993, devendo a ratificação ser procedida pela instância máxima de deliberação da entidade, sob pena de nulidade.

$\$ 5^{\circ}$ Aplica-se o disposto neste artigo às entidades qualificadas como Organizações Sociais, na forma da Lei n. 9.637, de 15 de maio de 1998, e às entidades qualificadas como Organizações da Sociedade Civil de Interesse Público, na forma da Lei n. 9.790, de 23 de março de 1999, relativamente aos recursos por elas administrados oriundos de repasses da União, em face dos respectivos contratos de gestão ou termos de parceria. 
trizes para a política de fomento, de colaboração e de cooperação com organizações da sociedade civil; e altera as Leis ns. 8.429, de 2 de junho de 1992, e 9.790, de 23 de março de 1999", na forma da redação conferida pela Lei n. 13.204, de 14 de dezembro de 2015. Assim, o termo de colaboração passa a ser o instrumento jurídico de consecução de planos de trabalho de iniciativa da administração pública, para celebração de parcerias com organizações da sociedade civil que envolvam a transferência de recursos financeiros, (art. 16), ao passo que o termo de fomento se propõe à mesma finalidade, mas para a realização de planos de trabalho propostos pelas próprias organizações da sociedade civil (art. 17).

\subsection{DELIMITAÇÃO DAS ESPÉCIES DE TRANSFERÊNCIAS: AS TRANSFERÊNCIAS LEGAIS E AS TRANSFERÊNCIAS VOLUNTÁRIAS}

Ao proceder ao estudo das transferências voluntárias, verifica-se uma extrema dificuldade na definição precisa dos seus contornos, motivada, preponderantemente, por dois fatores: a) o alcance do conceito e a natureza jurídica por exclusão, conforme definição extraída do artigo 25 da Lei de Responsabilidade Fiscal; b) a existência de institutos próximos e assemelhados, exigindo-se esforço do intérprete para sua perfeita caracterização.

Tendo já sido objeto de análise o conceito e a natureza jurídica constante do artigo 25 da LRF, convém diferenciar as transferências voluntárias de algumas outras modalidades de transferências, particularmente inseridas no âmbito das transferências legais, caracterizadas por sua regulamentação em lei específica, que normalmente contém aspectos procedimentais das transferências, a aplicação dos recursos e a respectiva prestação de contas.

As transferências legais comportam algumas classificações. Notadamente quanto à discricionariedade de aplicação dos recursos, podem ser classificadas em transferências desvinculadas ou transferências vinculadas. Exemplo clássico de transferência desvinculada, não atrelada a um fim específico, é a compensação financeira devida aos Estados, Distrito Federal e Municípios, em razão do resultado da exploração de petróleo ou gás natural, de recursos hídricos para fins de geração de energia elétrica, de recursos minerais em seus respectivos territórios, plataformas continentais, mar territorial ou zona econômica exclusiva (Lei Federal n. 7.990, de 28 de dezembro de 1989).

Por seu turno, as transferências legais vinculadas podem ser subdivididas em: a) transferências automáticas; b) transferências fundo a fundo; e c) transferências diretas ao cidadão. 


\subsubsection{Transferências automáticas}

As transferências legais automáticas são aquelas que não se submetem a qualquer requisito por parte da entidade recebedora, não se sujeitando também à realização de convênios ou a quaisquer espécies de ajustes. Aponta-se, nessa medida, alguns exemplos.

A Resolução n. 8, de 20 de março de 2013, do Conselho Deliberativo do Fundo Nacional de Desenvolvimento da Educação do Ministério da Educação, "estabelece procedimentos para a transferência de recursos financeiros ao Distrito Federal, a estados e Municípios, por intermédio dos órgãos gestores da educação profissional e tecnológica", com vistas "à oferta de Bolsa-Formação no âmbito do Programa Nacional de Acesso ao Ensino Técnico e Emprego (PRONATEC), bem como para a execução e a prestação de contas desses recursos, a partir de 2013". Tem como fundamento a Lei Federal n. 12.513, de 26 de outubro de 2011, que instituiu o PRONATEC, e a Portaria n. 168, de 2013, do Ministério da Educação, que dispôs sobre a oferta da Bolsa-Formação no âmbito do mesmo Programa.

Consoante estabelece o artigo $1^{\circ}$ da Resolução, constituem seus objetivos estabelecer procedimentos para a realização de:

(...) transferência de recursos financeiros ao Distrito Federal e a estados, por intermédio de seus órgãos gestores de educação profissional e tecnológica, e a prefeituras municipais ou às suas respectivas instituições de educação profissional e tecnológica da administração indireta, para que ofereçam vagas em cursos de educação profissional técnica de nível médio e cursos de formação inicial e continuada ou qualificação profissional, por intermédio da Bolsa-Formação do Programa Nacional de Acesso ao Ensino Técnico e Emprego (Pronatec) [assim como a orientação da] execução dos recursos transferidos e a obrigatória prestação de contas de sua aplicação ao Fundo Nacional de Desenvolvimento da Educação (FNDE).

Consoante disposto no artigo $4^{\circ}$, "A transferência de recursos financeiros mencionada no inciso I do art. $1^{\circ}$ será feita sem necessidade de convênio, ajuste, acordo, contrato ou instrumento congênere" (grifo nosso), salientando o artigo $5^{\circ}$ que "os recursos financeiros de que trata esta resolução serão transferidos em favor do órgão gestor da educação profissional e tecnológica do Distrito Federal ou do Estado ou em favor da prefeitura municipal ou de sua respectiva instituição de educação profissional e tecnológica da administração indireta”. Menciona, ainda, seu artigo $6^{\circ}$ que "os recursos financeiros de que trata esta resolução serão creditados, mantidos e geridos em conta corrente específica para a Bolsa-Formação do Pronatec, a ser aberta pelo FNDE em agência do Banco do Brasil S/A indicada pelo parceiro ofertante". 
Verifica-se, assim, tratar-se de transferência legal e automática, não submetendo o ente recebedor dos recursos a quaisquer requisitos ou exigências, nem tampouco à celebração prévia de convênio.

Entretanto, sobressai a ausência de uniformidade na definição das diversas espécies de transferências, evidenciada pela classificação de alguns programas específicos. A esse propósito, menciona-se o caráter conflituoso da classificação das transferências inseridas no âmbito do Programa Nacional de Alimentação Escolar (PNAE), habitualmente inseridas no âmbito das transferências legais automáticas. Nesse sentido, merece menção a definição veiculada por Aldo de Campos Costa:

As transferências automáticas consistem no repasse de recursos financeiros sem a utilização de convênio, ajuste, acordo ou contrato, mediante o depósito em conta corrente específica, aberta em nome do beneficiário. Essa forma de transferência é empregada na descentralização de recursos em determinados programas da área de educação. São objeto de transferências automáticas pelo Fundo Nacional de Desenvolvimento Escolar (FNDE), que fiscaliza os recursos remetidos com a finalidade de estimular o desenvolvimento da educação nos estados, Distrito Federal e Municípios: a) o Programa Nacional de Alimentação Escolar - PNAE; (b) o Programa Dinheiro Direto na Escola PDDE (TRF5 ACR 200405000132349); c) o Programa Nacional de Apoio ao Transporte do Escolar - PNATE (TRF-5 HC 00038642120104050000 ); d) o Programa de Educação de Jovens e Adultos - PEJA (TRF-5 INQ 200781010002366); e) o Programa Brasil Alfabetizado - PBA; e f) o Programa Fundescola (STJ HC 62998). ${ }^{82}$

Assim, não obstante a frequente inclusão do mencionado programa enquanto exemplo de transferência legal automática, registre-se a existência de entendimento expresso do Tribunal de Contas da União acerca da natureza voluntária da aventada transferência. Nesse sentido, ficou estabelecido no AC 2368-34/13-P:

Ainda no julgado supracitado, o relator indica o fator determinante para que se possa diferenciar a transferência obrigatória da transferência voluntária, qual seja, a imposiçáo de exigência por parte do ente concedente - no caso, a União - para a realização do repasse de recursos. O legislador complementar, destaca-se, definiu as exigências mínimas para que um ente federativo possa repassar recursos a outro, podendo outras exigências serem definidas, a cada ano, na Lei de Diretrizes Orçamentárias do ente concedente (ex vi do art. 25 da Lei Complementar n. 101/2000 - LRF). ${ }^{83}$

O Tribunal lembra ainda que o simples fato de estar prevista em lei não torna uma transferência obrigatória. Nesse sentido, restou assim consignado:

82 COSTA, Aldo de Campos. Competência para julgar desvios de verbas federais. Consultor Jurídico, 11 jul. 2013.

83 BRASIL. Tribunal de Contas da União. Acórdão 2.368-34/2013-Plenário. Processo 035.358/2012-2. Relator: Ministro Benjamin Zymler. Brasília, 4 set. 2013. Diário Oficial da Uniāo, Brasília, 13 set. 2009, Seção 1, p. 139. Grifo nosso. 
23. Cumpre destacar, porém, que, apesar de a transferência obrigatória ser caracterizada pela existência de "determinação constitucional ou legal", isso não significa dizer que toda e qualquer transferência prevista em lei deve ser tida como obrigatória ou incondicional. Mesmo porque, se assim o fosse, inexistiriam transferências voluntárias, dado que a realização de qualquer despesa pública depende de previsão em lei. ${ }^{84}$

Ao cuidar especificamente do PNAE, aduz o mencionado acórdão:

24. A meu ver, o PNAE é um exemplo de que nem toda transferência prevista em lei possui natureza obrigatória. Prova disso é que a Lei 11.947/2009 (que rege o programa) fixa exigências mínimas típicas da essência de uma transferência voluntária, sendo que a realização dos repasses pode ser suspensa se Estados, Distrito Federal e Municípios não as cumprirem.

(...)

25. Assim sendo, creio que os aportes federais de recursos para educação, por meio do PNAE, consistem em transferências voluntárias, uma vez que são recursos transferidos a título de cooperação e mediante o atendimento de diversos requisitos impostos pelo ente concedente. ${ }^{85}$

Outro aspecto abordado pelo acórdão diz respeito ao equívoco verificado quanto à dispensa de formalização de convênio para a caracterização da transferência enquanto obrigatória. Nessa medida, o fato de a transferência dispor de natureza automática, não significa necessariamente que ela apresente a natureza obrigatória. Trata-se apenas de diferentes instrumentos de materialização da entrega de recursos. Nesse sentido, preconiza o acórdão:

27. Vale mencionar que o fato de a Lei n. 11.947/2009 estabelecer que "a transferência dos recursos financeiros, objetivando a execução do PNAE, será efetivada automaticamente pelo FNDE, sem necessidade de convênio, ajuste, acordo ou contrato, mediante depósito em conta corrente específica" não deve conduzir à conclusão de que se trata de uma transferência obrigatória. Consoante já dito, as duas modalidades de cooperação entre os entes federativos são as transferências obrigatórias e as transferências voluntárias, sendo o repasse automático apenas um instrumento congênere ao convênio utilizado para a viabilização dessas transferências intergovernamentais. Em outras palavras, ser a transferência automática e dotada de regularidade não significa ser ela obrigatória e incondicional. A distinção fundamental entre esses dois gêneros de transferência, como visto, é a exigência ou não de condição para entrega de recursos. ${ }^{86}$

84 BRASIL. Tribunal de Contas da União. Acórdão 2.368-34/2013-Plenário. Processo 035.358/2012-2. Relator: Ministro Benjamin Zymler. Brasília, 4 set. 2013. Diário Oficial da União, Brasília, 13 set. 2009, Seção 1, p. 139.

BRASIL. Tribunal de Contas da União, cit.

BRASIL. Tribunal de Contas da União, cit. 
Verifica-se, assim, que as classificações propostas não são estanques, o que torna ainda mais complexa a diferenciação das transferências voluntárias de seus institutos afins.

\subsubsection{Transferências fundo a fundo}

Por meio do mecanismo de transferência fundo a fundo, os recursos são transferidos diretamente de um fundo a outro, sem a necessidade de formalização de convênios ou instrumentos congêneres. Assim, o repasse ocorre diretamente de um fundo nacional para fundos estaduais ou municipais, podendo também ocorrer da esfera estadual para as municipais. Os exemplos mais comuns estão relacionados às transferências do Fundo Nacional de Saúde e do Fundo Nacional de Assistência Social.

A respeito das transferências fundo a fundo pondera Aldo de Campos Costa: As transferências fundo a fundo (STJ CC 122376) consistem em um instrumento de descentralização de recursos disciplinado em leis específicas que se caracterizam pela remessa direta de recursos provenientes de fundos da esfera federal para fundos da esfera estadual, municipal e do Distrito Federal, dispensando a celebração de convênios. As transferências fundo a fundo, na área de saúde, desenvolvem-se no âmbito do SUS (STF RE 196982), por meio do Fundo Nacional de Saúde - FNS (TRF-4 Inq 200404010290995), e, na área de assistência social, são realizadas pelo Fundo Nacional de Assistência Social - FNAS (TRF5 INQ 00094599820104050000). ${ }^{87}$

Contudo, a utilização de fundos como intermediários e a eventual dispensa da celebração de convênios ou contratos de repasse não constituem critério de classificação ou exclusão do repasse enquanto transferência voluntária, devendo-se, da mesma forma, verificar não apenas a automaticidade do repasse, mas também a ausência de exigências a serem observadas pelos entes recebedores dos recursos.

\subsubsection{As transferências diretas de renda}

Outra modalidade de transferência legal vinculada a um fim específico reside nas transferências diretas ao cidadão, assim conceituadas por Aldo de Campos Costa:

(...) as transferências diretas ao cidadão referem-se aos programas que concedem benefício monetário mensal à populaçôes-alvo do programa. Nesta modalidade de transferência, compete ao Município a missão de operacionalizar os programas, por meio de açôes como o credenciamento junto ao Governo Federal e a manutenção do cadastro das pessoas beneficiadas e, ainda, instituir os conselhos de controle social. Pode-se citar como programas vinculados a esta modalidade de transferência: o Programa Bolsa Família (TRF-2 ACR 200551030006863) e o Programa de Erradicação do Trabalho Infantil - PETI (TRF-5 Inq 200905001118012). ${ }^{88}$

87 COSTA, Aldo de Campos, cit.

88 COSTA, Aldo de Campos, cit. 
Pela análise dos dados disponibilizados pela Secretaria do Tesouro Nacional, assim como pelo Portal da Transparência dos Recursos Públicos federais, chamam a atenção alguns tópicos relacionados especialmente ao Programa Bolsa Família. Não obstante se trate de benefício inserido em um programa de transferência direta de renda, sacada mensalmente pelo beneficiário junto à Caixa Econômica Federal, o orçamento contempla a realização de transferências voluntárias entre os entes federados para a consecução do programa.

A previsão de gestão centralizada do Programa encontra guarida no artigo $8^{\circ}$ da Lei Federal n. 10.836, de 9 de janeiro de 2004, que cria o Programa Bolsa Família e dá outras providências:

Art. $8^{\circ}$ A execução e a gestão do Programa Bolsa Família são públicas e governamentais e dar-se-ão de forma descentralizada, por meio da conjugação de esforços entre os entes federados, observada a intersetorialidade, a participação comunitária e o controle social.

$\$ 1^{\circ}$ A execução e a gestão descentralizadas referidas no caput serão implementadas mediante adesão voluntária dos Estados, do Distrito Federal e dos Municípios ao Programa Bolsa Família. $\$ 2^{\circ}$ Fica instituído o Índice de Gestão Descentralizada do Programa Bolsa Família - IGD, para utilização em âmbito estadual, distrital e municipal, cujos parâmetros serão regulamentados pelo Poder Executivo, e destinado a:

I - medir os resultados da gestão descentralizada, com base na atuação do gestor estadual, distrital ou municipal na execução dos procedimentos de cadastramento, na gestão de benefícios e de condicionalidades, na articulação intersetorial, na implementação das ações de desenvolvimento das famílias beneficiárias e no acompanhamento e execução de procedimentos de controle;

II - incentivar a obtenção de resultados qualitativos na gestão estadual, distrital e municipal do Programa; e

III - calcular o montante de recursos a ser transferido aos entes federados a título de apoio financeiro.

$\$ 3^{\circ}$ A União transferirá, obrigatoriamente, aos entes federados que aderirem ao Programa Bolsa Família recursos para apoio financeiro às açóes de gestão e execução descentralizada do Programa, desde que alcancem índices mínimos no IGD.

$\$ 4^{\circ}$ Para a execução do previsto neste artigo, o Poder Executivo Federal regulamentará:

I - os procedimentos e as condições necessárias para adesão ao Programa Bolsa Família, incluindo as obrigaçôes dos entes respectivos;

II - os instrumentos, parâmetros e procedimentos de avaliação de resultados e da qualidade de gestão em âmbito estadual, distrital e municipal; e

III - os procedimentos e instrumentos de controle e acompanhamento da execução do Programa Bolsa Família pelos entes federados.

$\$ 5^{\circ}$ Os resultados alcançados pelo ente federado na gestão do Programa Bolsa Família, aferidos na forma do inciso I do $₫ 2^{\circ}$ serão considerados como prestação de contas dos recursos transferidos. 
$\$ 6^{\circ}$ Os Estados, o Distrito Federal e os Municípios submeterão suas prestações de contas às respectivas instâncias de controle social, previstas no art. $9^{\circ}$, e, em caso de não aprovação, os recursos financeiros transferidos na forma do $₫ 3^{\circ}$ deverão ser restituídos pelo ente federado ao respectivo Fundo de Assistência Social, na forma regulamentada pelo Poder Executivo Federal.

$\$ 7^{\circ} \mathrm{O}$ montante total dos recursos de que trata o $\$ 3^{\circ}$ não poderá exceder a $3 \%$ (três por cento) da previsão orçamentária total relativa ao pagamento de benefícios do Programa Bolsa Família, devendo o Poder Executivo fixar os limites e os parâmetros mínimos para a transferência de recursos para cada ente federado. (Grifo nosso)

Os entes federados podem aderir voluntariamente ao Programa (art. $8^{\circ}, \S 1^{\circ}$ ). Contudo, uma vez preenchidos os requisitos de adesão, os entes farão jus ao recebimento de um apoio financeiro às suas ações de gestão (art. $8^{\circ}, \$ 2^{\circ}$, inciso III), que deverão ser obrigatoriamente entregues pela União, na forma prevista pelo $₫ 3^{\circ}$ do mencionado dispositivo. Dessa forma, não obstante as transferências sejam computadas no âmbito das transferências voluntárias, a lei se refere à obrigatoriedade de transferência da União para os entes que aderirem ao programa para a gestão do benefício. ${ }^{89} \mathrm{~A}$ adesão é voluntária, mas o repasse passa a ser obrigatório pela União.

Observa-se uma vez mais a simbiose haurida das classificações efetuadas, o que acaba por tornar ainda mais nebulosa a classificação das transferências de recursos, implicando na falta de definição precisa acerca de seus contornos, com reflexos diretos na mensuração de seus volumes nos orçamentos dos entes federados.

\subsection{A INTRODUÇÃO DO MARCO REGULATÓRIO DA SOCIEDADE CIVIL E OS REFLEXOS SOBRE AS TRANSFERÊNCIAS VOLUNTÁRIAS}

Alterações significativas foram inseridas na sistemática dos convênios e das próprias transferências voluntárias com a promulgação da Lei Federal n. 13.019, de 31 de julho de 2014, que introduziu o chamado Marco Regulatório da Sociedade

89 Conforme informaçôes extraídas do site do Ministério do Desenvolvimento Social, "a gestão de benefícios é o conjunto de procedimentos e atividades desenvolvidos pelo governo federal e pelos gestores municipais na operação do Programa Bolsa Família, que garantem o pagamento dos benefícios às famílias", compreendendo os seguintes procedimentos e atividades: (a) habilitação de famílias inscritas no Cadastro Único; (b) seleção de famílias; (c) concessão de benefícios; (d) atividades de administração de benefícios, como bloqueio, desbloqueio, suspensão, reversão de suspensão, cancelamento e reversão de cancelamento; e (e) revisão cadastral das famílias beneficiárias" (BRASIL. Ministério do Desenvolvimento Social e Combate à Fome. Gestão de Benefícios. Portal do MDS, publicado em 27 jul. 2015. Disponível em: http://mds.gov.br/assuntos/ bolsa-familia/gestao-do-programa/gestao-de-beneficios. Acesso em: 19 set. 2015). 
Civil. Mencionado diploma estabelece o regime jurídico das parcerias entre a administração pública e as organizações da sociedade civil, em regime de mútua cooperação, para a consecução de finalidades de interesse público e recíproco, mediante a execução de atividades ou de projetos previamente estabelecidos em planos de trabalho inseridos em termos de colaboração, em termos de fomento ou em acordos de cooperação; define diretrizes para a política de fomento, de colaboração e de cooperação com organizações da sociedade civil; e altera as Leis ns. 8.429, de 2 de junho de 1992, e 9.790, de 23 de março de 1999, na forma da redação conferida pela Lei n. 13.204 , de 2015. O artigo $1^{\circ}$ do mencionado diploma é bastante elucidativo acerca da abrangência de suas disposições, valendo aqui a sua reprodução:

Art. $1^{\circ}$ Esta Lei institui normas gerais para as parcerias entre a administração pública e organizaçôes da sociedade civil, em regime de mútua cooperação, para a consecução de finalidades de interesse público e recíproco, mediante a execução de atividades ou de projetos previamente estabelecidos em planos de trabalho inseridos em termos de colaboração, em termos de fomento ou em acordos de cooperação. (Redação dada pela Lei n. 13.204, de 2015)

Dessa forma, os antigos convênios celebrados com entidades da sociedade civil, regidos pela legislação vigente, em especial o Decreto Federal n. 6.170/2007 e a Portaria Interministerial n. 507/2011, que disciplinam a transferência de recursos mediante convênios e contratos de repasse, passam agora a constituir objeto de termo de colaboração ou termo de fomento, sob a égide na novel legislação. Após a inovação, restam a antiga denominação, assim como o instrumento jurídico convênio, vocacionado aos acordos de cooperação - envolvendo ou não a transferência voluntária de recursos - entre entes da federação.

A própria legislação conceitua e delimita os campos das novas ferramentas, estabelecendo a diferenciação entre o termo de colaboração e o termo de fomento em seus artigos 16 e 17, com a redação conferida pela Lei n. 13.204, de 2015:

Art. 16. O termo de colaboração deve ser adotado pela administração pública para consecução de planos de trabalho de sua iniciativa, para celebração de parcerias com organizaçôes da sociedade civil que envolvam a transferência de recursos financeiros.

Parágrafo único. Os conselhos de políticas públicas poderão apresentar propostas à administração pública para celebração de termo de colaboração com organizações da sociedade civil.

Art. 17. O termo de fomento deve ser adotado pela administração pública para consecução de planos de trabalho propostos por organizações da sociedade civil que envolvam a transferência de recursos financeiros.

Dessa feita, o termo de colaboração passa a ser o instrumento jurídico de efetivação de transferências voluntárias de recursos para o implemento de planos de 
trabalho realizado em regime de mútua colaboração com entidades da sociedade civil, propostos pela administração pública, ao passo que o termo de fomento se propõe à mesma finalidade, mas para a realização de planos de trabalho propostos pelas próprias organizações da sociedade civil.

Ambos os termos, tanto o de colaboração como o de fomento, foram concebidos em substituição aos convênios, que hoje passam a ser restritos às transferências voluntárias de recursos efetuadas entre os entes da federação. Conforme fundamentação do Projeto de Lei n. 7.168/2014, de autoria do Senador Aloysio Nunes, que deu origem ao diploma, a elaboração da lei decorreu de alguns regramentos impostos pelo TCU, assim como de conclusões extraídas da CPI das ONGs. Mencionada justificativa aponta ainda para a lacuna legislativa que cercava a questão da transferência de recursos para as entidades da sociedade civil sem fins lucrativos, o que também é percebido em relação às transferências voluntárias de recursos entre os entes da federação. É apontada ainda a ausência de controle da execução dos ajustes celebrados com as entidades do terceiro setor, inclusive no tocante à avaliação do resultado obtido.

A questão da ausência de controle da execução também afeta as transferências voluntárias de recursos entre os entes federados, na medida em que a divulgação da efetivação das transferências e seus respectivos valores nominais não tem o condão de refletir se os recursos foram aplicados de forma efetiva em suas finalidades. Dessa forma, ainda que a instituição do SICONV represente um avanço no controle formal das transferências, não fornece meios para uma avaliação relativa aos resultados alcançados, donde resulta a necessidade de desenvolvimento de mecanismos aptos à aferição da observância do princípio da eficiência na realização de ajustes envolvendo transferências voluntárias de recursos. 
